\title{
Who Invests in the High-Tech Knowledge Base?
}

\author{
Matt Hopkins and William Lazonick*
}

\author{
Working Paper No. 14
}

\begin{abstract}
A nation must accumulate a high-tech knowledge base to prosper. In this paper, we provide a historical perspective on the interaction of household families, government agencies, and business enterprises, or what we call "the investment triad", in providing a foundation for the accumulation of a high-tech knowledge base in the United States. Households and governments interact by making investments in education. Governments and businesses interact in the development of the high-tech knowledge base by investing in research and development. Businesses and households interact to invest in the knowledge base through the employment relation. The quality of these interactions in terms of complementarity and sophistication are of critical importance to the productivity performance of investments in the knowledge base. Most discussions of investing in the high-tech knowledge base focus on investments made in R\&D by government and business as well as universities and non-profits. We argue that investment in R\&D does not capture the productivity of $R \& D$ in generating high-quality, low cost high-tech products, nor how the revenues from those products support the higher incomes of the broad base of employees in the high-tech labor force. Over the past decade total R\&D spending as a percent

\footnotetext{
* Hopkins: Researcher, The Academic-Industry Research Network (www.theAIRnet.org) (matthopking@yahoo.com)

Lazonick: Professor of Economics, University of Massachusetts Lowell; President, The Academic-Industry Research Network (william.lazonick@gmail.com), 12 Newport Road, Cambridge, MA 02140
} 
of GDP in the United States has remained high by historical standards, with Business-funded $R \& D$ exceeding the proportion of Government-funded $R \& D$ in the total. Yet there is a sense in the United States that over the past two to three decades the institutional arrangements for investing in the knowledge base have broken down. We hypothesize that the innovation problem resides in the interaction of the organizations - household families, government agencies, and business enterprises - in the investment triad. Using the investment-triad framework, this report provides an historical overview of the evolution of the institutional arrangements for investing in the knowledge base in the United States since the mid-19th century, culminating in an agenda for research on the contemporary operation and performance of the investment triad.

JEL Codes: No. H1, I2, L2, O3, P1

This report has been done as part of a project on the development of high-technology capabilities in the United States and the implications for stable and equitable economic growth. The project is being carried out by The Academic-Industry Research Network (theAIRnet) in collaboration with Philip Moss, Hal Salzman, and Öner Tulum. 


\section{The Knowledge-Creating Economy}

There is a widespread consensus that a nation cannot transform from poverty to affluence without acquiring advanced technological knowledge. The accumulation of this knowledge cannot be done all alone or all at once. Knowledge must be learned, and the complexity of technological knowledge requires that large numbers of people with various types of highly specialized knowledge interact in collective learning processes. Moreover, as a learning process, the knowledge that was acquired yesterday forms an indispensable foundation for the knowledge that can be acquired today. Therefore, the accumulation of knowledge depends on learning processes that are not only collective but also cumulative. It is the collective and cumulative character of learning processes that creates a role for organizations, as distinct from markets, in the allocation of resources in the operation of the economy. ${ }^{1}$

How does a nation accumulate a knowledge base that enables it to attain a high level of affluence? And how might a knowledge base that has supported an affluent nation become, at a later stage in the nation's history, depleted or obsolete? What are the implications of the globalization of knowledge accumulation that has permitted the transformation of some nations from poverty to affluence in the space of a few decades, and who does that process affect the ability of a rich nation to sustain its investment in the knowledge base required to remain affluent?2 Finally, how might dominance of value-extracting over value-creating activities affect investment in the knowledge base?

In this report, we offer some preliminary answers to these questions for the case of the United States. We provide an historical overview of how, driven in large part by the Cold War, in the decades after World War II the United States accumulated the most powerful knowledge base that the world has ever seen. Then, from the late 1970s, despite high levels of business spending on research and development (R\&D), the United States was unable to sustain that position. Meanwhile some Asian nations, most notably Japan, China, South Korea, and Taiwan, have been making investments in the knowledge base that provide them with technological capabilities that the United States now lacks. Meanwhile, notwithstanding major differences among its nations, the European Union, through Horizon 2020, has implemented an €80 billion strategic initiative for investing in innovation over the next six years. ${ }^{3}$ There is no guarantee that the Europeans will be successful, but the fact is that no equivalent strategic initiative to invest in the high-tech knowledge base exists in the United States.

In our view, such a strategic initiative must be grounded in an analytical framework that comprehends who invests in the knowledge base and how different types of investors interact with one another to develop the knowledge base. Modern societies rely on three types of organizations to make these investments in the knowledge base: household families, government agencies, and business enterprises. Taken together, we call these three types of organizations "the investment triad". One might be tempted to include educational institutions as organizations that invest in the high-tech knowledge base. We argue, however, that the structure and performance of educational institutions as organizations within which learning occurs results from the interaction of the

\footnotetext{
1 William Lazonick, "The Theory of the Market Economy and the Social Foundations of Innovative Enterprise," Economic and Industrial Democracy, 24, 1, 2003: 9-44; William Lazonick, "The Chandlerian Corporation and the Theory of Innovative Enterprise," Industrial and Corporate Change, 19, 2, 2010: 317-349; William Lazonick, "Innovative Enterprise and Shareholder Value," Law and Financial Markets Review, 8, 1, 2014: 52-64.

2 See Dan Breznitz and John Zysman, eds., The Third Globalization: Can Wealthy Nations Stay Rich in the Twenty-First Century?, Oxford University Press, 2013: 232-276.

3 European Commission, “Horizon 2020", at http://ec.europa.eu/programmes/horizon2020/en/what-horizon-2020
} 
Who Invests in the High-Tech Knowledge Base?

investment strategies of households, governments, and businesses. Using the investment-triad framework, we can explore the functions of universities and nonprofit research institutes as sites of organizational learning in the process of investing in the high-tech knowledge base.

How then do the triadic organizations invest in a nation's knowledge base?

Household families invest in the education of the young with a view to providing them with the knowledge that they will need to function as adults, who will then have families of their own. The relation between spouses as providers of household income, the quality of education that the young receive, and the number of years over which they receive their education are all critical components of household investments in the knowledge base. No modern society has embarked on a path of development in which most of the population has attained higher standards of living without a well-financed primary, secondary, and tertiary education system. ${ }^{4}$

Government agencies support this process by providing schooling that households, each acting on their own, could not afford. Different nations in different eras have had different policies for partitioning the cost of investing in an educated labor force between government agencies and household families. Government agencies also can be charged with investing in the creation, through basic and applied research, of new scientific and engineering (also known as "high-tech) knowledge that does not now exist. Again, different nations in different eras have had different strategies for investing in this science and engineering knowledge base. We also argue that an understanding of how the development and utilization of a high-tech knowledge base can result in superior economic performance (which we define as stable and equitable economic growth) depends on investment in a social science knowledge base that can explain the relation between the generation of superior productive capabilities and the achievement of superior economic performance.

Business enterprises make use of the knowledge base generated by government agencies and household families as a foundation for making investments in physical and human capital that can generate products that these businesses can sell to generate revenues. In high-tech fields, business enterprises may have to make specialized investments in in-house capabilities to absorb the hightech knowledge that investments by government agencies have created. In many cases, government agencies make these investments in knowledge-creation through business enterprises in the forms of research contracts and subsidies.

The investment strategies of households, governments, and businesses are integrally related. Households and governments interact through investments in education. Governments and businesses interact in the development of the high-tech knowledge base. Businesses and households interact through the employment relation. The quality of these interactions in terms of complementarity and sophistication are of critical importance to the productivity performance of funds that are invested in the knowledge base.

Business enterprises provide adults in household families with employment that should enable them to support their families. Through formal and on-the-job training, business enterprises also invest in the knowledge of some or all of the people whom they employ. These enterprises then have an incentive to retain the people whom they have trained. They often do so through pay

\footnotetext{
${ }^{4}$ William Lazonick, Sustainable Prosperity in the New Economy? Business Organization and High-tech Employment in the

United States, Upjohn Institute for Employment Research, ch. 5
} 
increases, often by way of promotions. Indeed, pay increases for valued employees in stable employment is the fundamental way in which the standard of living for households rise over time.

Investments in the knowledge base by household families, government agencies, and business enterprises must be financed. Investments in educating the labor force are generally financed by some combination of after-tax household incomes supplemented by household debt and tax revenues of local, state, and federal governments and government debt. To some extent business enterprises finance the education of the labor force through the taxes they pay, philanthropic contributions based on business fortunes, and direct payments to employees for the education of themselves or their children as part of the employment contract. Ultimately, however, the ability of a society to afford investments in the knowledge base requires that the knowledge developed through these investments is utilized. And in a modern society, to ensure the utilization of the knowledge base that has been developed, we rely primarily on its employment by business enterprises that need to produce and sell competitive (high quality, low cost) products to survive.

Summing up this introduction to "who invests in the high-tech knowledge base?": a) the investment triad of household families, government agencies, and business enterprises combine to make these investments; b) a society institutes arrangements for sharing the costs of making these investments among these three types of organizations; and c) there are different financing mechanisms that can be used for investment in the knowledge base. A nation cannot develop and prosper without investment in the high-tech knowledge base. The incentives and abilities of households, governments, and businesses to invest in the high-tech knowledge base are of great national concern. How can a nation structure its institutions to ensure that its household, government, and business organizations invest in the high-tech knowledge base? And what should a nation do if the institutional arrangements for investing in the high-tech knowledge base break down?

These questions are important ones for the United States in the second decade of the $21^{\text {st }}$ century. Most discussions of investing in the high-tech knowledge base focus on investment in R\&D by government and business as well as universities and non-profits. We argue that investment in R\&D does not capture the productivity of $R \& D$ in generating high-quality low cost high-tech products while generating higher incomes to the broad base of employees in the high-tech labor force. Over the course of the $20^{\text {th }}$ century, the United States became a world leader in investing in the high-tech knowledge base. Yet there is a sense, as we document in this paper, that over the past two or three decades, the arrangements for investing in the knowledge base have broken down.

This concern is not evident, however, in calculations of U.S. R\&D spending as a percent of GDP over the past six decades. Using data collected by the National Science Foundation from 1953 to 2011, Figure 1 shows that over the past decade total R\&D spending as a percent of GDP in the United States has remained high by historical standards, and that Business-funded R\&D is proportionally greater than Government-funded R\&D in the total. If there is a problem with investment in the hightech knowledge base in the United States in recent decades, it is not apparent in the statistics on $\mathrm{R} \& \mathrm{D}$ spending.

We hypothesize that the innovation problem resides in the interaction of the organizations household families, government agencies, and business enterprises - in the investment triad. Too much of the cost of educating the labor force seems to have been shifted onto households, even as the quantity and quality of "middle-class" employment opportunities that business enterprises make available to households have declined. A key dimension of this decline in employment opportunities appears to be a much-reduced commitment by businesses to train and retain their employees. And business executives often lobby the government to increase public investments in 
Who Invests in the High-Tech Knowledge Base?

the knowledge base even as they choose to distribute almost all of their profits to shareholders in the forms of stock buybacks and cash dividends. Meanwhile, in the name entrepreneurship and innovation, business executives argue for lower tax rates on profitable companies and wealthy households, depriving governments of tax revenues that, among other things, are required to sustain investment in the knowledge base. ${ }^{5}$

Figure 1. U.S. R\&D Spending as a Percent of GDP, Total, Government, and Business Funding 1953-2011

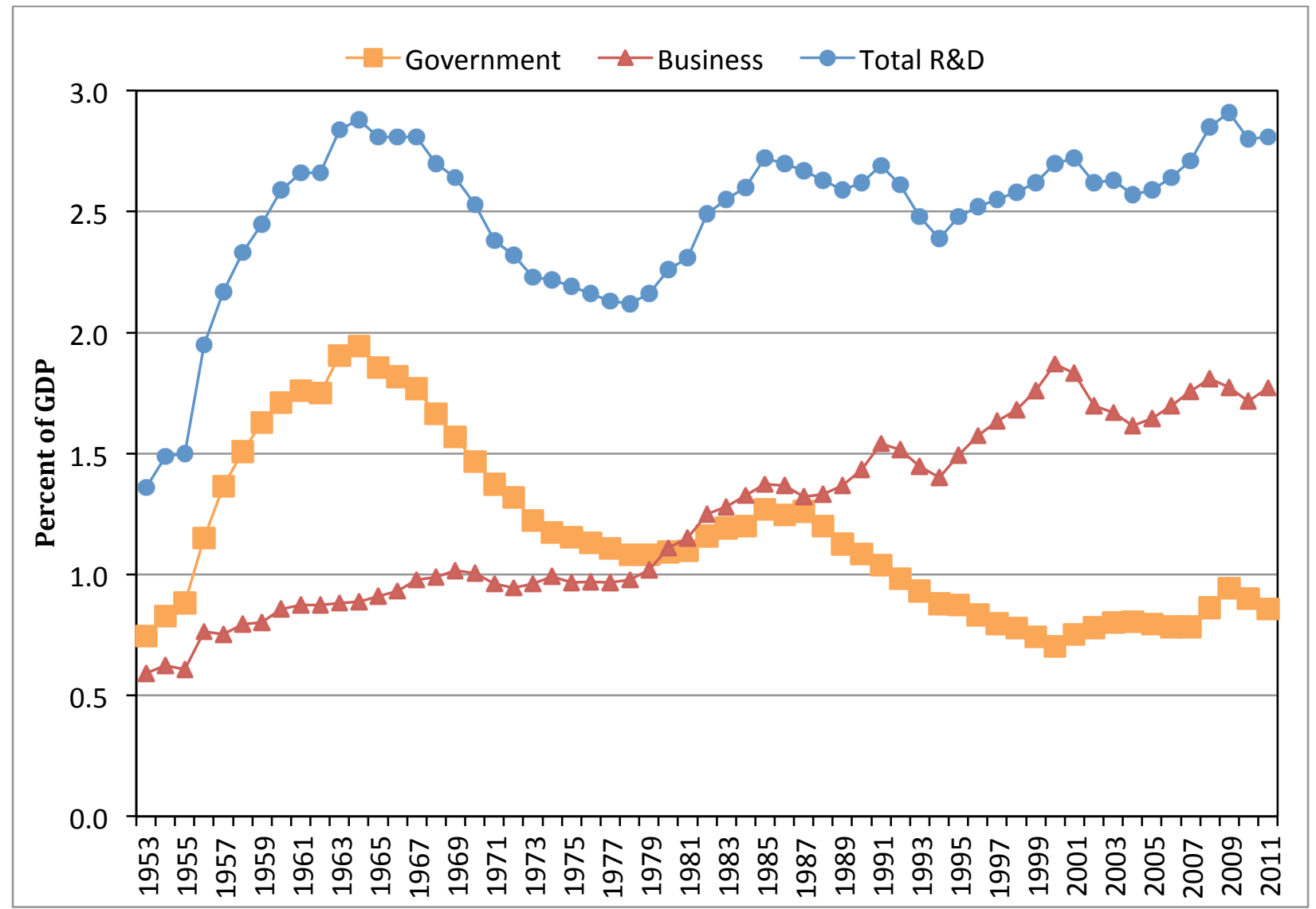

Note: Universities and Nonprofits omitted; from 1953 through 2011 R\&D spending by either did not exceed $0.1 \%$ of GDP in any year.

Source: National Science Board, Science and Engineering Indicators 2014, National Science Foundation,

February 2014, Tables 4-1, 4-6.

Using the investment-triad framework, this report provides an historical overview of the evolution of the institutional arrangements for investing in the knowledge base in the United States since the mid-19th century, culminating in an agenda for research on the contemporary operation and performance of the investment triad. Section 2 provides an overview of the roles of households, governments, and businesses in investing in the knowledge base from approximately the mid-19th century to the mid-20th century. Section 3 delves into the bodies of statistical data on R\&D spending by government and business, and the role of universities in the process, to see what they reveal about who invests in the high-tech knowledge base. Section 4 provides an interpretation of what

5 William Lazonick, "Profits Without Prosperity: Stock Buybacks Manipulate the Market and Leave Most Americans Worse Off," Harvard Business Review, September 2014: 46-55; William Lazonick, "Labor in the Twenty-First Century: The Top

0.1\% and the Disappearing Middle Class," AIR Working Paper \#14-08/01 at http://www.theairnet.org/v3/. 
Who Invests in the High-Tech Knowledge Base?

these data on investment in the knowledge base can, or cannot, tell us about the quality of that investment and the implications for performance of the United States as an innovative economy. Finally, through a framework that analysis "innovative business models", we highlight a number of key questions for further research.

\section{Institutional Foundations of Knowledge-Base Investment}

\section{a) Creating an Educational System}

The United States developed as a nation in the first half of the $19^{\text {th }}$ century without any formal institutional arrangements for investing in the knowledge base. Local communities would create primary schools to provide elementary education to their children, but it was only with Horace Mann's "Common School Movement", launched in Massachusetts in the late 1830s, that the campaign for universal free primary education appeared on the political agenda. The movement gained support from the last half of the 1840s with the mass immigration to the United States of impoverished and illiterate Irish, driven from their homeland by potato famine. 6 By 1870 all states in the nation had laws mandating universal public primary education, typically organized at the local level and financed by local property taxes.

Meanwhile most secondary schools remained private, as were colleges, topped by what would later become known as the elite "Ivy League" universities. ${ }^{7}$ With the exception of Cornell, which was founded in 1865 as a land-grant college, the other Ivy League universities were founded in the colonial era by religious denominations. The learning that occurred in these universities was knowledge that had scant relevance for investments in a knowledge base that could provide a platform for economic development.

One might have thought that once public primary education had become ubiquitous, the next step in building a universal education system would be investment in public secondary education for the mass population. Yet a unique feature of the evolution of the U.S. educational system as a whole was the creation from the mid-1860s of a national system of tertiary education well in advance of a system of universal public secondary education that could feed into it. This leapfrogging of the secondary education system was the result of the Morrill Land Grant College Act of 1862.8 Each state in the nation was given 30,000 acres of land (or land scrip) for each senator or representative to sell, the funds then devoted "to the endowment, support, and maintenance of at least one college where the leading object shall be, without excluding other scientific and classical studies, and including military tactics, to teach such branches of learning as are related to agriculture and the mechanic arts, in such manner as the legislatures of the States may respectively prescribe, in order to promote the liberal and practical education of the industrial classes in the several pursuits and professions in life." 9

The social movement that culminated in the Morrill Act of 1862 began in the 1830s and 1840s when advocates of the farmers and artisans who constituted the American yeomanry argued that

\footnotetext{
6 Michael B. Katz, The Irony of Early School Reform: Educational Innovation in Mid-Nineteenth Century Massachusetts, second edition, Teachers College Press, 2001.

7 Ivy League was a term coined in the 1920s, first as the informal and then the formal name of the football league in which the old elite universities and Cornell were organized.

8 The following draws on Louis Ferleger and William Lazonick., "The Managerial Revolution and the Developmental State: The Case of U.S. Agriculture." Business and Economic History, 22, 2, 1993: 67-98; Louis Ferleger and William Lazonick, "Higher Education for an Innovative Economy: Land-Grant Colleges and the Managerial Revolution in America." Business and Economic History, 23, 1, 1994: 116-128.

${ }^{9}$ http://www.ourdocuments.gov/doc.php?flash=true\&doc=33\&page=transcript
} 
these "industrious classes" needed their own institutions of higher education that could give them the cultural and political standing in American society that Harvard and Yale bestowed upon the "learned classes". In the 1850s the southern states blocked the efforts of these reformers to secure federal funding for these new universities but the creation of the Confederacy in 1861 removed that obstacle. The Morrill Act carried the condition that the college or colleges that were being endowed had to be launched within five years of the land grant. In some states, private money supplemented the land grant; for example, in New York State, Ezra Cornell stepped forward with a large donation, and had the university named after him. In Massachusetts, the land grant was divided between the University of Massachusetts in Amherst for agricultural education and Massachusetts Institute of Technology for mechanical arts education. A second Morrill Act in 1890 added annual cash support to the land-grant colleges, stipulating that any state in which the existing university barred admission to blacks had to set up a separate black college. In the last decades of the $19^{\text {th }}$ century, therefore, the United States created a national system of public higher education that was explicitly intended to be of use to American households involved in industry.

While the land-grant colleges were intended to have a practical orientation suitable to farmers and artisans, the original intention of the first Morrill Act was not to invest in the knowledge base for the sake of industrial development. Rather its intention was to elevate the cultural and political standing of the "industrious classes" vis-à-vis the "learned classes" in American society so that the yeomanry could participate in "the several pursuits and professions in life." It was for that reason that the proponents of institutions of higher education for farmers and artisans insisted that the land-grant universities provide four-year bachelor's degrees that would have the same academic standing as those awarded at the private universities that catered to the "learned classes".

In practice, however, in the quarter century after the Morrill Act of 1862, enrollments in the new land-grant colleges faced two major obstacles. The first problem was that many of the offspring of farmers and artisans who were interested in enrolling in the colleges did not have the necessary secondary qualifications to enter into this type of tertiary education. Only $2.0 \%$ of the population of 17 -year-olds were high school graduates in 1870 , rising to just $3.5 \%$ by 1890.10 To accommodate many of those who wanted a public college education, the land-grant colleges had to provide preparatory courses, which could add a year or more to the length of time that it would take to get a bachelor's degree. The second problem was that, even then, it was difficult to convince the parents and children of farming and artisan families that it was worth spending four years in college rather than spending that time getting on-the-job experience on the farm or in the workshop. In short, the households for whose benefit the land-grant colleges were supposed to operate did not view the colleges as suitable or viable institutions through which they could invest in the knowledge base of the next generation of farmers or artisans.

By the 1890s, however, the land-grant colleges began to come into their own precisely because the students who attended them did not expect to be among the farming and artisanal workforces in their future careers. Rather they expected to become college-educated professional, technical, or administrative employees. Opportunities could be found in the burgeoning nationwide government bureaucracy under the direction the U.S. Department of Agriculture (USDA) that included the landgrant colleges as key institutions. They were also found in the corporate bureaucracies of the nation's rapidly growing big businesses that began to systematically recruit four-year college graduates for professional, technical and administrative positions. It was the rise of professional government agencies and managerial business enterprises that created a demand for the graduates

\footnotetext{
10 National Center for Education Statistics, Digest of Education Statistics, 1997, Table 99 at
} http://nces.ed.gov/programs/digest/d97/d97t099.asp 
of land-grant colleges, thus making it economically attractive for "industrious" household families to invest in their children's knowledge by sending them to these institutions of higher education.

\section{b) Investing in the Agricultural Knowledge Base}

The USDA was founded in 1862, the same year as the first Morrill Act, for the purpose of increasing crop productivity and disseminating new scientific research of relevance to agriculture. Productivity in agriculture was important both to the American standard of living and the U.S. balance of trade. As late as 1929 (the first data available), food absorbed 23\% of the personal disposable income of Americans (the figure is now about 11\%, and Americans have the cheapest food in the world). ${ }^{11}$ Food exports (crude and manufactured) represented $56 \%$ of total U.S. merchandise exports in $1880,42 \%$ in 1890 , and still $40 \%$ in 1900.12 In 1887 , with the natural productivity of once-fertile land reaching its limits as the frontier disappeared, Congress passed the Hatch Act to fund agricultural experiment stations throughout the nation to be operated in conjunction with the land-grant universities.

Up to this time, U.S. universities had been viewed as places where bright students were educated by learned professors, but these schools did not function as formal research institutions. Some U.S. professors had spent time at German universities, which in the last half of the $19^{\text {th }}$ century were the world's leading institutions for scientific discovery, maintaining close ties to Germany's growing chemical industry. American professors generally engaged in knowledge transfer at U.S. universities as individual scholars, not as part of government-funded research projects. From the mid-1870s, however, through state-level initiatives, agricultural experiment stations were set up in collaboration with land-grant universities. In 1887, on the eve of the Hatch Act, 12 formally organized state-level experiment stations were in existence. By 1900, aided by the Hatch Act, that number had grown to 56 with a total of 678 employees. ${ }^{13}$

The agricultural experiment stations constituted the first important institutional arrangement for the integration of higher education into the operation of the U.S. economy. Embedded as they were in the land-grant colleges, the agricultural experiment stations transformed the functions of these institutions of higher education. Subsequent Congressional legislation increased federal government funding of the experiment stations, with the Smith-Lever Act of 1914 financing cooperative extension services through which agricultural experts, known as county agents, could both disseminate new knowledge to farmers and collect data from farms that were relevant to the experiment stations' research programs. In the early 1920s there were about 2,100 counties with agricultural extension agents. ${ }^{14} \mathrm{~A}$ century later this institutional structure that integrates basic research with agricultural production through the medium of public state universities still exists, and has made the United States a leader in agricultural research.

\footnotetext{
11 U.S. Department of Agriculture, Economic Research Service, Table 8 "Table 8-Food expenditures by families and individuals as a share of disposable personal money income," at http://www.ers.usda.gov/data-products/foodexpenditures.aspx

12 U.S. Census Bureau, Historical Statistics of the United States from the Colonial Times to the Present, Government Printing Office, 1976, p. 890.

13 Vernon Carstensen, "The Genesis of an Agricultural Experiment Station," Agricultural History, 31, 1, 1960: 13-20.

14 William A. Lloyd, “County Agricultural Agent Work Under the Smith Lever Act, 1914 to1924," U.S. Department of Agriculture Miscellaneous Circular No. 59, May 1936 at https://archive.org/stream/countyagricultur59lloy\#page/n3/mode/2up
} 
Who Invests in the High-Tech Knowledge Base?

\section{c) Government and Business in Science-Based Industries}

The agricultural knowledge base also helped to provide a foundation more generally for life sciences research, which from the 1930s came under the jurisdiction of the National Institutes of Health (NIH). The origins of the NIH go back to 1887 when, at the Marine Hospital, a government facility on Staten Island, New York, a one-room bacteriological laboratory was established to do research on cholera and other infectious diseases. ${ }^{15}$ In 1891, the New York laboratory relocated to Washington DC., where, as the Hygienic Laboratory, its main activity was inspecting and licensing biologic products intended for human use. In 1930 it was renamed the National Institute of Health with a federal government mandate to engage in "the investigation of infectious and contagious diseases, and matters pertaining to the public health." 16 In 1936 the National Institute of Health employed 177 people in some capacity and had 21 major research projects under way. In 1937 Congress established the National Cancer Institute, alongside the National Institute of Health. In 1938 and 1939 the annual budget of these two research facilities was $\$ 464,000$, and by 1945 it had increased by almost five times in real terms to a still modest $\$ 2.8$ million. In 1948 , with the creation of the National Heart Institute, the National Institutes of Heath (that is, the current plural NIH) was formed to encompass all of the specialized research institutes. In the six years after the war the NIH budget exploded, reaching \$65 million in 1951, 23 times its 1945 level in real terms. By that time there were five separate research centers within the NIH. In 2013 there were 27 specialized institutes within the $\mathrm{NIH}$, with a budget of $\$ 29.3$ billion, down from $\$ 30.9$ billion in each of the previous three years. In 2004 the NIH budget peaked in real terms, at a level 59 times what it had been in 1951.

During the 1920s and 1930s, the new discipline of aeronautics was the other major area for U.S. government investment in the high-tech knowledge base. From the founding of the National Advisory Committee for Aeronautics (NACA) in 1915, the U.S. government played a role in supporting aeronautics research. At the time of NACA's founding, with the Great War underway, it was recognized that the United States lagged the Europeans in both aeronautics research and capabilities. In 1917, therefore, with U.S. entry into the war, NACA launched the Langley Memorial Aeronautics Laboratory that became, according to the U.S. Centennial Commission of Flight, "the most advanced aeronautical test and experimentation facility in the world."17 In the 1920s NACA did pioneering wind tunnel research that resulted in the development of low-drag cowlings for aircraft engines. In the 1930s NACA focused on the design of airfoils (most importantly wings) to increase the lift of aircraft. In 1958 NACA was absorbed into the National Aeronautics and Space Administration (NASA), created in response to "Sputnik", the Soviet Union's successful launch into space of the first artificial satellite. In the $21^{\text {st }}$ century, the United States remains the world aeronautics leader. In 2013 aerospace accounted for 36.2\% of all U.S. Advanced Technology Product (ATP) exports, but only $11.2 \%$ of imports. The United States ran a trade deficit of $\$ 131.3$ billion in information-and-communication technologies (ICT) and a deficit of $\$ 81.3$ billion across all ten ATP categories combined, but had a surplus of $\$ 70.9$ billion in aeronautics. ${ }^{18}$

\footnotetext{
15 National Institutes of Health, "Chronology of Events," at http://www.nih.gov/about/almanac/historical/chronology_of_events.htm

16 E. K. Foltz, "National Institute of Health," The American Scholar, 5,4, 1936: 495-500. See History of the NIH, http://history.nih.gov/exhibits/history/docs/page_04.html

17 The National Advisory Commission for Aeronautics (NACA), "Aviation Comes of Age" at http://www.century-offlight.net/Aviation\%20history/coming\%20of\%20age/NACA.htm

18 US Census Bureau, "Foreign Trade: ATP Data - Imports and Exports - ATP Group by Country," at http://www.census.gov/foreign-trade/statistics/product/atp/2013/12/atpctry/index.html. The ATP category next closest to aeronautics with a trade surplus was weapons, which accounted for $1.1 \%$ of total ATP exports and had a trade surplus of $\$ 2.5$ billion.
} 
From the beginning of the $20^{\text {th }}$ century in the chemical and electrical industries of the second industrial revolution, major business enterprises took the lead in investing in the high-tech knowledge base by creating in-house research labs that sought to systematize the search for new knowledge and its integration into products and processes. During the $19^{\text {th }}$ century and beyond, the U.S. industrial landscape was replete with individual scientists, engineers, and tinkerers, some of whose inventions, as in the cases of Thomas Edison and Alexander Graham Bell, would have major impacts on the knowledge base of the United States and indeed of the world. ${ }^{19}$ The major impact came when, from the turn of the century, some of the companies that grew large on the basis of their proprietary control over these inventions began looking for ways both to protect the value of their existing intellectual property and to take industrial lead in generating new knowledge.

General Electric, formed through the merger of Edison General Electric and Thomson-Houston in 1892, launched its corporate research laboratory in Schenectady, New York in 1900. Bell Laboratories was founded in 1925 as a joint venture between American Telephone \& Telegraph (AT\&T) and its wholly owned manufacturing company, Western Electric. In between the founding of GE Labs and Bell Labs, major corporate research labs were set up at companies such as Kodak in photographic equipment, DuPont in chemicals, and Westinghouse in electrical power. ${ }^{20}$ According to David Mowery and Nathan Rosenberg, 1,250 industrial research labs were established between 1919 and 1936, and another 388 between 1937 and 1946. In 1921 there were 2,775 scientists and engineers doing research in these labs, increasing to 6,320 in 1927 and to 10,927 in 1933, the year in which the national unemployment rate rose to almost $25 \%$. Indeed, throughout the Great Depression, U.S. industrial companies invested in research facilities, increasing total employment of research personnel in them to 27,777 in $1940 .{ }^{21}$ Less surprisingly, the increase in employment of research personnel in industry continued during World War II, and in 1946 the number stood at 45,941 .

Most of these research labs were set up to protect and extend the existing intellectual property of the companies, but over time some of the labs generated new scientific discoveries with important commercial applications. For example, in 1932 Irving Langmuir, a scientist who had worked at GE Labs from 1909 where he had invented the gas-filled incandescent light bulb, won the Nobel Prize in Chemistry for his work in surface chemistry that permitted the elimination of blackening of the glass in light bulbs. ${ }^{22}$ During the 1930s, the DuPont research lab invented nylon, which turned into an enormous financial bonanza for the company, and provided the subsequent justification for several decades of basic and applied research at DuPont. ${ }^{23}$

\section{d) World War II and the Endless Frontier}

As a result of this investment in corporate research, the United States possessed unprecedented potential to develop technology during World War II. For example, during the war, Raytheon,

\footnotetext{
19 See Ross Thomson, “The Government and Innovation in the United States: Insights from Major Innovators," paper presented at the 2012 Business History Conference, Business and Economic History Online at http://www.thebhc.org/publications/BEHonline/2012/beh2012.html

20 On the history of U.S. industrial research see David A. Hounshell, "The Evolution of Industrial Research in the United States," in Richard S. Rosenbloom and William J. Spencer, eds., Engines of Innovation: U.S. Industrial Research at the End of an Era, Harvard Business School Press, 1996.

21 David C. Mowery and Nathan Rosenberg, Technology and the Pursuit of Economic Growth, Cambridge University Press, 1989, pp. 61-74.

22 Leonard S. Reich, "Irving Langmuir and the Pursuit of Science and Technology in the Corporate Environment," Technology and Culture, 24, 2, 1983: 199-221.

23 David A. Hounshell and John Kenly Smith, Jr., Science and Corporate Strategy: DuPont R\&D, 1902-1980, Cambridge University Press, 1988.
} 
founded as the American Appliance Company in Cambridge, Massachusetts in 1922, played a central role in advancing radar technology, while Motorola, founded as the Galvin Manufacturing Company in Chicago, Illinois in 1928, was in the forefront of the introduction of mobile radio communications.

A British Royal Air Force Officer, Frank Whittle, invented the modern jet engine in Britain in 1930,24 but during the war, the British transferred the Whittle engine to the U.S. government, which turned it over to General Electric for product development. ${ }^{25}$ At that time GE, one of the world's leading electrical power companies, had no experience in aeronautics research, but it had been carrying out research on gas turbine engines since 1903. GE's jet engines did not enter use during World War II, but after the war GE was the leader in developing the technology for the U.S. military. Then in 1974, GE entered the civilian jet engine industry through CFM International, a joint venture with the French state-owned company SNECMA (now part of Safran), producing mid-sized turbojet engines for the A300, the first generation of Airbus planes. Building on the correlated successes of Airbus and CFM, GE moved into the production of higher thrust engines on its own, emerging as the world leader in the jet-engine industry. ${ }^{26}$

The mobilization of industrial production for war resulted in the unprecedented interaction of business and government personnel in the development and utilization of scientific and engineering knowledge. Major U.S. industrial corporations exited World War II with muchenhanced manufacturing and research facilities. Now there was the need to ramp up government research to support investment in the nation's knowledge base. The clarion call for government investment on scientific research was Vannever Bush's Science - The Endless Frontier published in July 1945. In 1922 at the age of 32, Bush had been a founder of the company that became Raytheon. In the 1930s, he was dean of the MIT School of Engineering and later chairman of NACA. By the time he wrote Science - The Endless Frontier, Bush was the head of the U.S. Office of Scientific Research and Development, responsible for administering all military research during World War II.

Science - The Endless Frontier was Bush's response to a letter that he had received from President Franklin Roosevelt in November 1944, in which the first two paragraphs read:

The Office of Scientific Research and Development, of which you are the Director, represents a unique experiment of team-work and cooperation in coordinating scientific research and in applying existing scientific knowledge to the solution of the technical problems paramount in war. Its work has been conducted in the utmost secrecy and carried on without public recognition of any kind; but its tangible results can be found in the communiques coming in from the battlefronts all over the world. Some day the full story of its achievements can be told.

There is, however, no reason why the lessons to be found in this experiment cannot be profitably employed in times of peace. The information, the techniques, and the research experience developed by the Office of Scientific Research and Development and by the thousands of scientists

\footnotetext{
24 Whittle first patented his engine in 1930, and, over the next decade sought to produce a usable technology, founding Power Jets Limited in 1936. In August 1944, the Whittle engine produced by Power Jets powered the Gloster Meteor, although it was the Germans, with the Messerchmitt Me232, who could lay claim to the first jet plane in service. BigAl Keeper, "The Gloster Meteor: Britain's First Operational Military Jet," December 26, 2006, at http://www.bbc.co.uk/dna/ptop/plain/A12746162. We are grateful to Martyn Roetter for this reference.

25 T. L. Jones, "Frank Whittle's W2B Turbojet: United Kingdom versus United States Development," at http://www.enginehistory.org/GasTurbines/W2B.shtml; see also "The Hush-Hush Boys: GE Engineer Speaks About a Top Secret Program That Launched the Jet Age in America," GE Report, July 16, 2012, at http://www.gereports.com/post/77296347909/the-hush-hush-boys-ge-engineer-speaks-about-a-top

${ }^{26}$ See William Lazonick and Andrea Prencipe, "Dynamic Capabilities and Sustained Innovation: Strategic Control and Financial Commitment at Rolls-Royce plc," Industrial and Corporate Change, 14, 3, 2005: 1-42.
} 
Who Invests in the High-Tech Knowledge Base?

in the universities and in private industry, should be used in the days of peace ahead for the improvement of the national health, the creation of new enterprises bringing new jobs, and the betterment of the national standard of living. ${ }^{27}$

Science - The Endless Frontier called for national investment in basic scientific research in peacetime to fight a war against disease, to ensure national security, and to help achieve full employment. The first objective could be achieved by an expansion of what would become the National Institutes of Health, the foundations of which as we have seen were already in place before the war. The second objective could be achieved through peacetime research carried out by the military; in the late 1940s and 1950s, the Office of Naval Research, created in 1946, would play an important role in this regard, and in 1958, in response to Sputnik, President Eisenhower launched the Advanced Research Projects Agency (later, with the addition of Defense in the title, known as DARPA). In pursuit of the last objective - full employment - Bush stressed the need to invest in "scientific capital":

To create more jobs we must make new and better and cheaper products. We want plenty of new, vigorous enterprises. But new products and processes are not born full-grown. They are founded on new principles and new conceptions which in turn result from basic scientific research. Basic scientific research is scientific capital. Moreover, we cannot any longer depend upon Europe as a major source of this scientific capital. Clearly, more and better scientific research is one essential to the achievement of our goal of full employment.

How do we increase this scientific capital? First, we must have plenty of men and women trained in science, for upon them depends both the creation of new knowledge and its application to practical purposes. Second, we must strengthen the centers of basic research which are principally the colleges, universities, and research institutes. These institutions provide the environment which is most conducive to the creation of new scientific knowledge and least under pressure for immediate, tangible results. With some notable exceptions, most research in industry and Government involves application of existing scientific knowledge to practical problems. It is only the colleges, universities, and a few research institutes that devote most of their research efforts to expanding the frontiers of knowledge.

Bush's call to invest in scientific capital was highly influential in the creation of the National Science Foundation in 1950. With a 2014 budget of $\$ 7.2$ billion (about 25\% the size of the NIH budget), the NSF's motto is "Where Discoveries Begin". Bush himself has been criticized (in our view correctly) for espousing a "linear model" of the relation between basic science and innovative products, a model that fails to recognize the interaction of government and business investment in the knowledge base in driving both the search for basic scientific knowledge and the integration of that knowledge into products and processes. ${ }^{28}$ Despite his own history as a founder of Raytheon and dean of the MIT School of Engineering, Bush gives no hint in Science - The Endless Frontier that corporate research might play a role in investment in scientific capital in post-war America.

\section{e) Old Economy Foundations of a New Economy Business Model}

In fact, as the research of John Servos has shown, since the 1890s, especially through its interaction with General Electric as well as the first technology-consulting firm Arthur D. Little, MIT had been

\footnotetext{
27 Letter from President Roosevelt to Vannever Bush, November 17, 1944, at https://www.nsf.gov/od/lpa/nsf50/vbush1945.htm\#transmittal

28 See Mowery and Rosenberg, Technology and the Pursuit of Economic Growth, ch. 6. See also Benoît Godin, "The Linear Model of Innovation: The Historical Construction of an Analytical Framework," at http://www.csiic.ca/PDF/Godin_30.pdf.
} 
Who Invests in the High-Tech Knowledge Base?

at the center of the development of an interactive university-corporate research model. ${ }^{29}$ David Noble demonstrated more generally corporate influence in the shaping of research and teaching at MIT in the decades before World War I. By the 1920s, as outcomes of Chandler's "managerial revolution", a number of MIT graduates had risen to positions of executive leadership in U.S. industrial corporations. ${ }^{30}$ During World War II, MIT was a major recipient of government funds for military-related research. ${ }^{31}$

Immediately after the war, MIT became the focal point for transferring this accumulation of scientific and engineering capability to the industrial economy. Georges Doriot, a professor of manufacturing at Harvard Business School who had become a U.S. Army General during World War II, teamed up with Ralph Flanders, president of the Federal Reserve Bank of Boston, and Karl Compton, president of MIT, to found American Research and Development Corporation (ARD). Regarded as the first formal venture-capital organization, ARD's express purpose was to transfer MIT's high-tech knowledge base to the industrial economy. Over the ensuing decades, both MIT and ARD were centrally involved in the growth of the Route 128 high-tech corridor to the north and west of Boston. ${ }^{32}$ ARD's biggest coup was the venture backing of Digital Equipment Corporation (DEC), launched in 1957 on the basis of technology developed at MIT for the SAGE Air Defense System. DEC went on to became the world leader in mini-computers, reaching peak employment of 126,000 in the late 1980s, before it was undone by the growing computing power of the microcomputer based on the IBM PC architecture using the Intel microprocessor and the Microsoft operating system.

The technology that launched the microelectronics revolution was the transistor, invented at Bell Labs in 1947 by John Bardeen, Walter Brattain, and William Shockley. All three had worked on military research during World War II, and the knowledge accumulated in those years set the stage for this technological breakthrough. ${ }^{33}$ In 1956, Bardeen, Brattain, and Shockley won the Nobel Prize in Physics for their invention. Meanwhile, in 1955, Shockley sought to work out a deal to start his own semiconductor laboratory at Raytheon, but when that fell through he secured backing from a Los Angeles-based medical device firm, Beckman Instruments, to set up a lab in Palo Alto, home of Stanford University.

Palo Alto, as it happened was also the home of Shockley's mother, but research on the events leading up the establishment of Shockley Semiconductor Laboratories in 1955 has shown that a key influence on Shockley's decision to locate there was Frederick Terman, Provost of Stanford University. Born in 1900, Terman received his doctorate in electrical engineering at MIT, where his thesis advisor was Vannevar Bush. Terman was then on the Stanford faculty from 1925 to 1941, where his most famous students turned out to be William Hewlett and David Packard. At Terman's urging, Hewlett and Packard set up an electronics testing equipment company bearing their names

\footnotetext{
29 John W. Servos, “Industrial Relations of Science: Chemical Engineering at MIT, 1900-1939," Isis, 71, 4, 1980: $530-549$.

30 David F. Noble, America by Design: Science, Technology, and the Rise of Corporate Capitalism, Knopf, 1977; William Lazonick, "Strategy, Structure, and Management Development in the United States and Britain," in K. Kobayashi and H. Morikawa, eds., Development of Managerial Enterprise, University of Tokyo Press, 1986: 101-146.

31 Stuart W. Leslie, "How the West Was Won: The Military and the Making of Silicon Valley," in William Aspray, ed., Technological Competitiveness: Contemporary and Historical Perspectives on the Electrical, Electronics, and Computer Industries, IEEE Press, 1993: 75-89.

32 Susan Rosegrant and David R. Lampe, Route 128: Lessons from Boston's High-Tech Community, Basic Books, chs. 2-4; David H. Hsu and Martin Kenney, "Organizing Venture Capital: The Rise and Demise of American Research \& Development Corporation, 1946-1973," Industrial and Corporate Change, 14, 4, 2005: 579-616.

33 Michael Riordan and Lillian Hoddeson, Crystal Fire: The Invention of the Transistor and the Birth of the Information Age, W. W. Norton, 1997.
} 
in a garage in Palo Alto in 1939.34 During World War II, Terman directed Harvard's Radio Research Laboratory, a secret military operation with over 800 personnel. At the end of the war, he returned to Stanford as dean of the School of Engineering, and, having been a major participant in the accumulation of technological capability on the East Coast, but committed to the West Coast, in his 1946-47 Dean's Report, Terman enunciated a vision of "indigenous innovation" for his region.

The west has long dreamed of an indigenous industry of sufficient magnitude to balance its agricultural resources. The war advanced these hopes and brought to the west the beginning of a great new era of industrialization. A strong and independent industry must, however, develop its own intellectual resources of science and technology, for industrial activity that depends upon imported brains and second-hand ideas cannot hope to be more than a vassal that pays tribute to its overlords, and is permanently condemned to an inferior competitive position. ${ }^{35}$

Terman was the driving force behind the creation of Stanford Industrial Park in 1951, which in the 1950s attracted research subsidiaries of many major industrial corporations doing work for the U.S. military. As Stuart Leslie has documented, the implantation of the "military-industry complex" in the vicinity of Stanford was the foundation for what would become the world's leading high-tech industrial district. ${ }^{36}$ Indeed, in convincing Shockley to set up shop in Palo Alto, Terman inadvertently started a process that over the next 15 years resulted in so many semiconductor startups that in 1971 an electronics journalist dubbed the district "Silicon Valley". ${ }^{37}$

To sum up a well-known story, Shockley recruited about 50 young scientists and engineers to work, in his Palo Alto lab, but by 1957, with the backing of an East Coast company, Fairchild Camera and Instrument, eight of them, including Gordon Moore and Robert Noyce, left to form Fairchild Semiconductor in nearby Mountain View, California. Then, from 1959, Fairchild's engineers and managers started leaving to form startups. As shown in Figure 2, from 1959 through 1970, 42 new semiconductor firms - 21 in 1968 and 1969 alone - were launched in the vicinity of Fairchild. By 1985 the number of Silicon Valley semiconductor startups since the founding of Fairchild totaled 125. Of these 125 firms, 32 were founded by at least one person who had left employment at Fairchild for that purpose, while another 35 companies were offspring from these "Fairchildren" (especially from National Semiconductor, Intel, Signetics, and Synertek). Fairchild's importance to the emergence of Silicon Valley was not only because it drew people and knowledge from the established R\&D labs of the electronic tube companies such as GE, RCA, Westinghouse, and Sylvania but also because it invested heavily in research, especially related to manufacturing processes for the mass production of diffused silicon transistors.

Following the founding of Fairchild, the first wave of Silicon Valley semiconductor startups consisted of 10 firms launched between 1959 and 1964 oriented toward military markets. Between 1955 and 1963, the annual value of total U.S. semiconductor production rose from $\$ 40$ million to $\$ 610$ million, with the proportion that was for the U.S. military varying between $35 \%$ and $48 \%$. In 1968 , when the value of U.S. semiconductor production stood at $\$ 1.2$ billion, the value of military production was still $25 \%$ of the total. By that time, integrated circuits accounted for $27 \%$ of the value of all U.S. semiconductor production, up from less than $3 \%$ five years earlier. Military demand

\footnotetext{
34 Stuart W. Leslie and Robert H. Kargon, “Selling Silicon Valley: Frederick Terman's Model for Regional Advantage.” Business History Review, 70, 4, 1996: 435-472.

35 Quoted in Stuart W. Leslie, The Cold War and American Science: The Military-Industrial Complex at MIT and Stanford, Columbia University Press, 1993, p. 55

36 Leslie, "How the West Was Won: The Military and the Making of Silicon Valley”; see also Stuart W. Leslie, "The Biggest 'Angel' of Them All: The Military and the Making of Silicon Valley," in Martin Kenney, ed., Understanding Silicon Valley: The Anatomy of an Entrepreneurial Region, Martin Kenney, ed. Palo Alto, CA: Stanford University Press, 2000; 48-67.

37 The following draws on Lazonick, Sustainable Prosperity, ch. 2
} 
represented $94 \%$ of integrated circuit production in 1963 and 37\% in 1968. Meanwhile, the price per integrated circuit declined from $\$ 31.60$ in 1963 to $\$ 2.33$ in 1968, thus dramatically increasing the economic viability of using integrated circuits for cost-conscious civilian markets. ${ }^{38}$

Figure 2. Silicon Valley Semiconductor Startups, with Direct and Indirect Spinoffs from Fairchild, Across Three Product Waves, 1955-1985

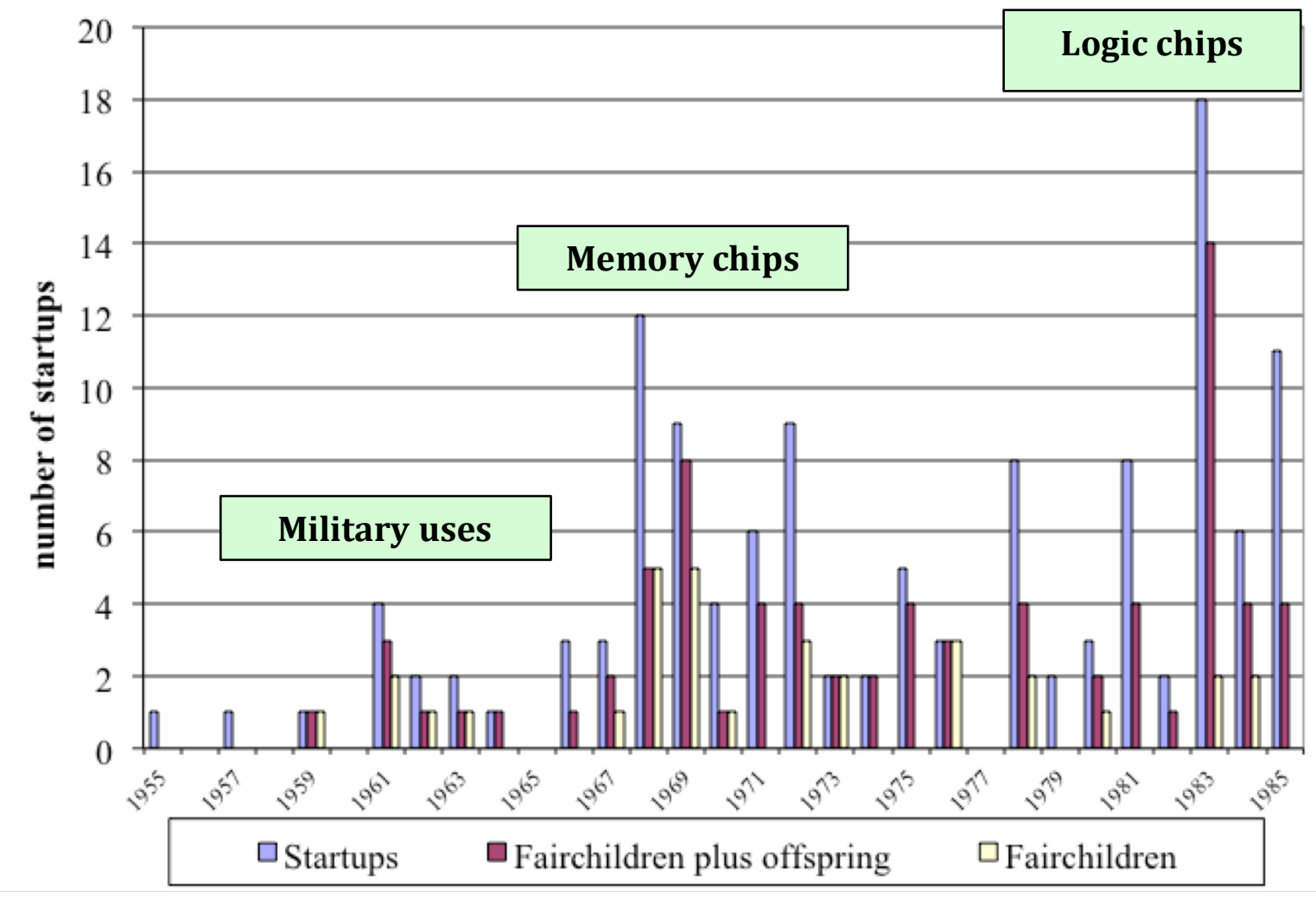

The realization of these commercial opportunities precipitated the second wave of Silicon Valley start-ups. From 1968 through 1972, the region hosted 40 semiconductor start-ups, 13 of which were Fairchildren and another eight of which were offspring of Fairchildren. Among these Fairchildren were Intel, founded in 1968 by Gordon Moore and Robert Noyce with Andrew Grove as their first employee, and Advanced Micro Devices (AMD), founded in 1969 by Jerry Saunders, who brought with him seven other Fairchild executives. ${ }^{39}$ When Moore and Noyce founded Intel to produce memory chips that could replace the magnetic coil memories then in use, they specifically declined to create a separate R\&D lab and refused to accept government contracts for research. ${ }^{40}$

As shown in Figure 3, there was a coevolution in the Silicon Valley region between venture-capital firm entrants and semiconductor startups. As with the founding of semiconductor firms, the pattern of venture-capital firm entrants exhibits three waves of growing amplitude, the first around 19581962, the second around 1968-1972, and the third around 1978-1983. East Coast money played an

\footnotetext{
38 John E. Tilton, International Diffusion of Technology: The Case of Semiconductors, Brookings Institution, 1971, pp. 90-91.

${ }^{39}$ Leslie Berlin, The Man Behind the Microchip, Oxford University Press, 2005, ch. 7; Christophe Lécuyer, Making Silicon Valley: Innovation and the Growth of High Tech, 1930-1970, MIT Press, 2006, ch. 7.

40 Ross Knox Bassett, To the Digital Age: Research Labs, Start-Up Companies, and the Rise of MOS Technology, Johns Hopkins University Press, 2002, ch. 6.
} 
important role in the first wave. The involvement of San Francisco Peninsula venture capital picked up slowly in the middle of the second wave, and toward the end of the period the semiconductor industry itself began contributing some of its well-known executives to the venture-capital industry. Many of the venture-capital firms co-located in a new complex at 3000 Sand Hill Road in Menlo Park, adjacent to Stanford University and with easy access to the San Jose and San Francisco airports. Through this community of interest, in 1973 the Western Association of Venture Capitalists transformed itself into the National Venture Capital Association, which became a powerful lobby for lower capital-gains tax rates and access to pension-fund money under the 1974 Employee Retirement Income Security Act. The second wave of semiconductor startups, therefore, not only gave Silicon Valley its name but also laid the foundation for an organized venture capital industry.

Figure 3. Silicon Valley Semiconductor Startups and Venture-Capital Entrants, 1957-1983

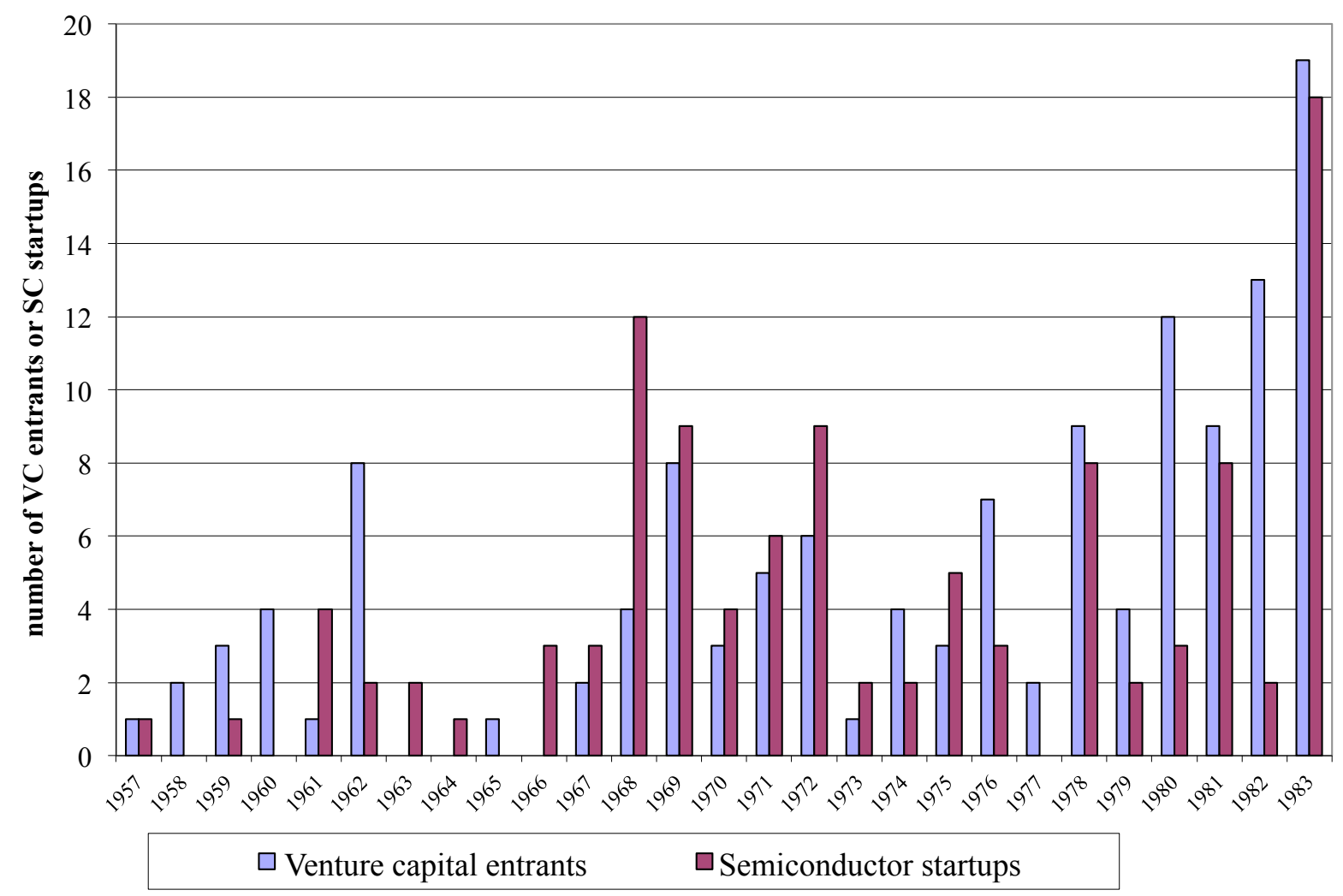

\section{f) Higher Education for American Workers}

In a 1984 article entitled "Venture Capital \& the Growth of Silicon Valley," William R. Hambrecht, founder and principal of Hambrecht \& Quist, a pre-eminent Silicon Valley investment banking and venture-capital firm, opined that "[t]here were three major catalytic events that occurred [from 1935 to 1950] that propelled our country into a position of technological leadership."

First, in the mid-1930s, the United States received a wave of European refugees, including some of the world's most prominent scientists and engineers. Second, during the Second World War the US government made massive investments in research and development. And third, in the aftermath of the Second World War, under the 'GI Bill', the US government paid for the university tuitions and subsistence costs of millions of people who might not otherwise have been able to afford a higher 
Who Invests in the High-Tech Knowledge Base?

education.

As Hambrecht summed up the impact: "A group of European scientists and engineers and the newly trained American engineers, fresh from their experiences in the R\&D labs, went back to the universities and trained a whole new generation of engineers who in the 1950s and 1960s created the microelectronics revolution." 41

While Hambrecht's perspective ignores the much longer history of government and business investment in the knowledge base that we have just reviewed, it does recognize the importance of government's role in the rise of the United States to world technological leadership in the postWorld War II decades, including the need to make university education available to a far larger proportion of the population than had heretofore been the case. While the Morrill Land-Grant College Acts created a national system of higher education in the late 19th century, it was only in the aftermath of World War II that a large proportion of the population gained ready access to it. In 1944 Congress passed the Serviceman's Readjustment Act, popularly known as the G.I. Bill of Rights, which provided funding to U.S. veterans of World War II to obtain college educations, buy homes, and start businesses. By the time the initial program ended in 1956, almost 50\% of the 16 million veterans of World War II had received education and training benefits under the G. I. Bill.

Figure 4 (reproduced from the U.S. Department of Education, 120 Years of American Education: $A$ Statistical Portrait) shows the impact of the G.I. Bill on the proportion of the population with bachelor's degrees in the aftermath of World War II. Before U.S. entry into the war, the number of 23-year-olds with bachelor's degrees was about 80 per 1,000, and then, as a result of military service, fell to about 50 per 1,000. But by 1950 it had increased to about 180 per 1,000. It then fell somewhat in the first half of the 1950s as the impact of the G.I. Bill receded. Whites gained far more from the G.I. Bill than blacks, in part because blacks had a far lower level of high-school attainment than whites (in 1947 only $8.0 \%$ of black males age 25 years or more had completed high school compared with $19.2 \%$ for white males), and hence a smaller proportion of black veterans had the educational credentials to go to college. And for those blacks who did possess the educational qualifications, many faced discrimination in college admissions. ${ }^{42}$

Figure 5 shows, for 1869-70 to 1989-90, the number of bachelor's and master's degrees received per 100, respectively, of high-school diplomas awarded four years earlier and bachelor's degrees awarded two years earlier. The decline in the bachelor's ratio until World War II was because, as mentioned earlier, the United States put in place a national system of public higher education before attainment of a secondary education became a norm. High-school graduates as a proportion of the 17-year-old population were $2.0 \%$ in $1870,6.3 \%$ in $1900,16.3 \%$ in 1920 , and $49.0 \%$ in 1940 . This figure was $42.7 \%$ in 1944 and $47.4 \%$ in 1946, but, as seen in Figure 5, the translation of highschool degrees into bachelor's degrees, and bachelor's degrees into master's degrees accelerated after the war. There was a sharp drop in both ratios in the first half of the 1950s, but then a sharp increase in the master's ratio to 1970 and in the bachelor's ratio during the 1980s. "Other" in Figure 6 includes endowment income, private gifts, grants, contacts, and, of growing importance in the post-war decades, revenues from university hospitals which increased from 5\% in 1949-50 to $9 \%$ in $1989-90.43$

\footnotetext{
41 William R. Hambrecht, "Venture Capital \& the Growth of Silicon Valley," California Management Review, 25, 2, 1984, pp. 74-75

42 John Bound and Sarah Turner., "Going To War And Going To College: Did World War II And The G.I. Bill Increase Education Attainment For Returning Veterans?" Journal of Labor Economics, 20, 4, 022: 784-815.

43 National Center for Educational Statistics, 120 Years of American Education: A Statistical Portrait, U.S. Department of Education, January 1993, p. 72.
} 
Who Invests in the High-Tech Knowledge Base?

Figure 6 provides long-run historical data on the proportional sources of funding for institutions of higher education, from 1909-10 to 1989-90. Tuition was about $25 \%$ at both the beginning and end of the 80-year period, and the contribution of state governments a few percentage points above that. The proportional contribution of tuition rose during the 1930s as state funding declined. Federal government funding averaged about 5\% until 1940 but then spiked sharply at the beginning of the 1940s and then again at the end of the 1940s. After dropping in the first half of the 1950 s and then rising again in the following decade, the federal government's share of funding declined as the states' share increased in the 1970s and households' share in the form of tuitions increased in the 1980s.

Figure 4. Bachelor's Degrees per 1,000 23-Year-Olds, 1889-90 to 1989-90

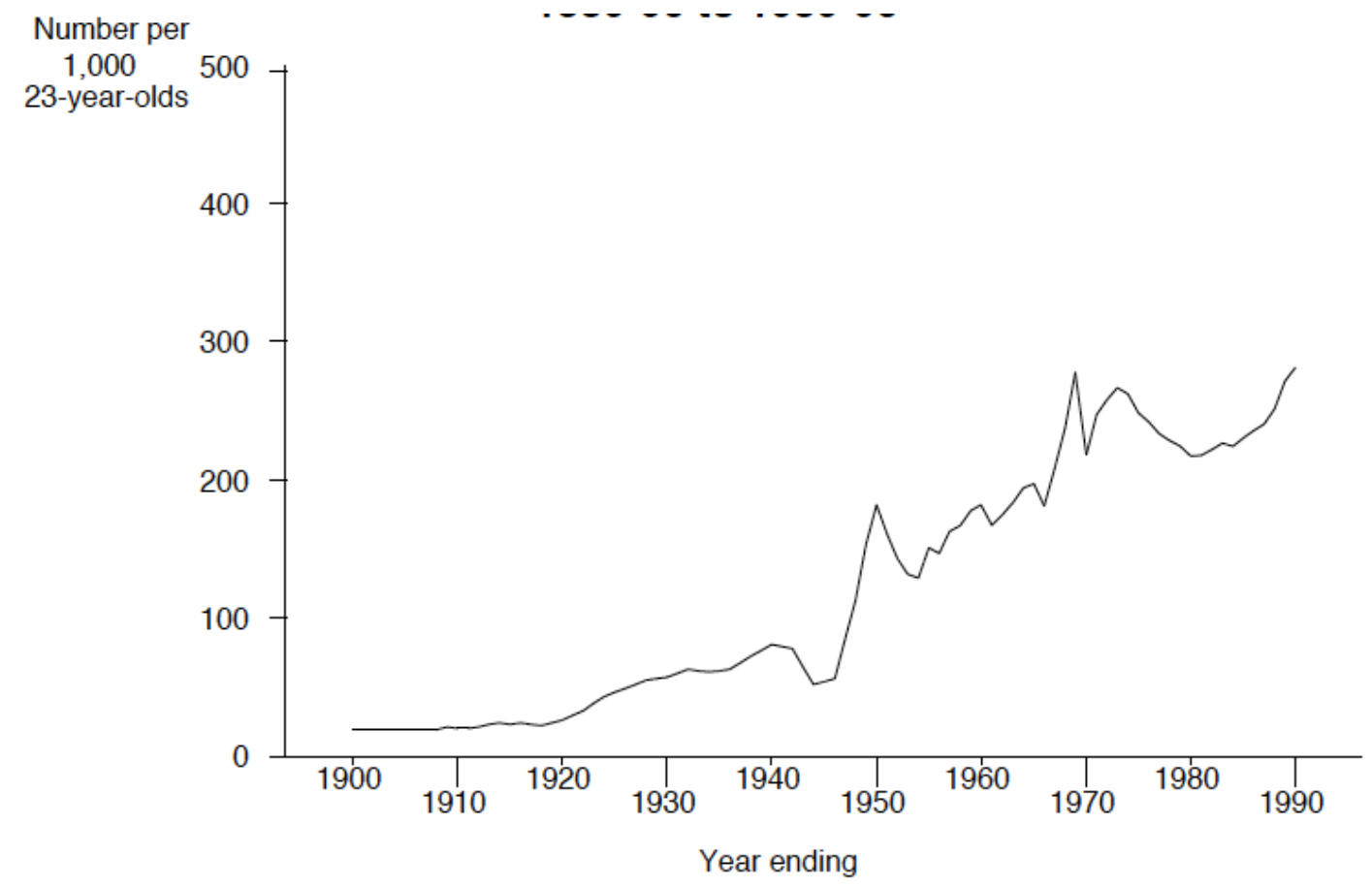

SOURCE: U.S. Department of Commerce, Bureau of the Census, Historical Statistics of the United States, Colonial Times to 1970; Current Population Reports, Population Estimates and Projections; and U.S. Department of Education, National Center for Education Statistics, Digest of Education Statistics, 1992. 
Who Invests in the High-Tech Knowledge Base?

Figure 5. Bachelor's Degrees per 100 High School Graduates 4 Years Earlier and Master's Degrees per 100 Bachelor's Degrees 2 Years Earlier, 1869-70 to1989-90

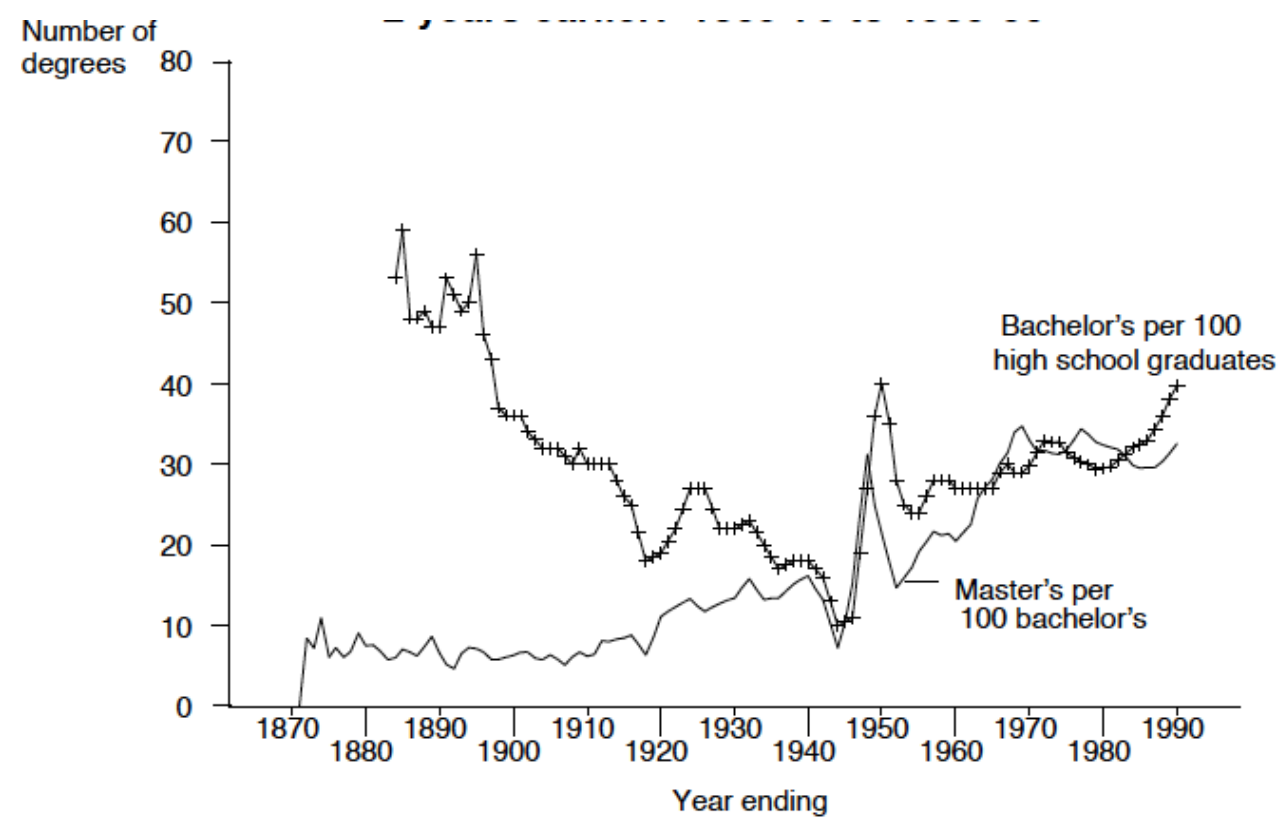

SOURCE: U.S. Department of Commerce, Bureau of the Census, Historical Statistics of the United States, Colonial Times to 1970; Current Population Reports, Population Estimates and Projections, various years; and U.S. Department of Education, National Center for Education Statistics, Digest of Education Statistics, various years.

Figure 6. Sources of Current Fund Revenue for Institutions of Higher Education, 1909-10 to 1989-90

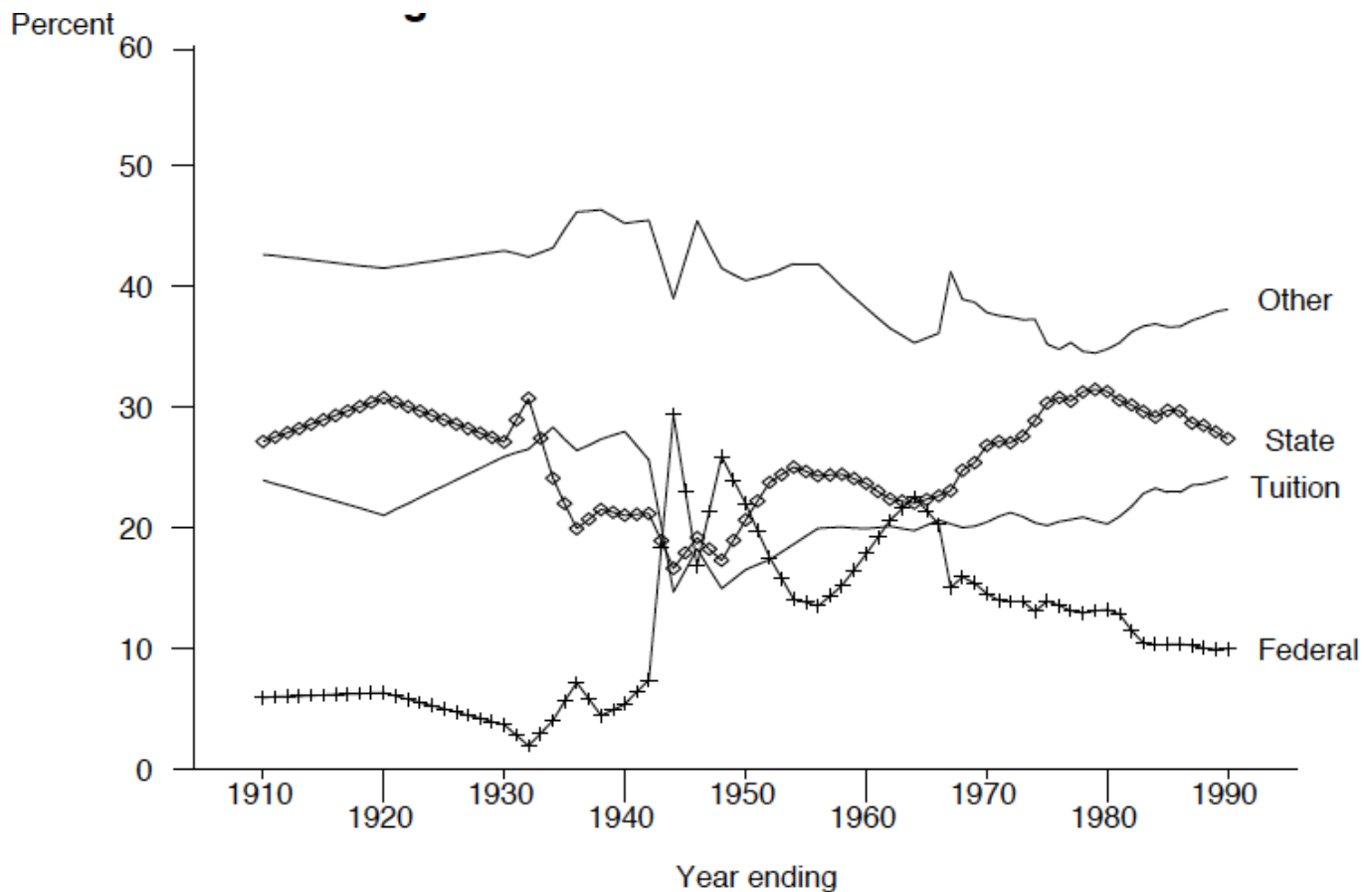

SOURCE: U.S. Department of Education, National Center for Education Statistics, Annual Report of the Commissioner; Biennial Survey of Education in the United States; Financial Statistics of Institutions of Higher Education; Digest of Education Statistics, 1992; and unpublished data. 
As a result of these investments, in the post-World War II decades an increasing proportion of the next generation of American workers could potentially enter the high-tech labor force. In the last two to three decades, American households have been facing challenges in funding investments in higher education, given the combination of rapid increases in the costs of education that they must bear, growing indebtedness, the loss of home equity value in the Great Recession of 2008-2009, and the ongoing disappearance of stable and remunerative employment opportunities, even for college graduates. In investing in the knowledge base, household families are one part of the investment triad that includes government agencies and business enterprises, working within the evolving institutional arrangements that we have adumbrated in this section. We will argue that an understanding of the transition from what Lazonick has called the Old Economy Business Model (OEBM) to the New Economy Business Model (NEBM) is critical to the analysis of who in investing in the high-tech knowledge base, and with what effect. Before engaging in that analysis however, we first need to get a quantitative perspective of government and business investment in the knowledge base, to which we now turn.

\section{R\&D Process as an Interactive Process: A Statistical Overview}

\section{a) An Overview of NSF R\&D Statistics}

We have seen in the historical overview provided in Section 2 of this report, that, given the availability of a suitably educated labor force, investment in the knowledge base requires the interaction of government agencies and business enterprises with universities as a critical location for both educating the future labor force and carrying out research activities. If we accept R\&D expenditures as suitable quantitative measures of the investments made by government agencies and business enterprises in the high-tech knowledge base as well as the role of universities in performing different types of research, what can the R\&D data tell us about the ways in which U.S. $\mathrm{R} \& \mathrm{D}$ is funded and performed?

The National Science Foundation's (NSF) Science and Engineering Indicators Digest provides the most complete dataset available on R\&D investment in the United States, tracking the expenditures made and the activities performed by Government, Business, Universities, Nonprofits and other sources. In aggregate, over the 59 years for which data are available (1953-2011), the NSF has recorded $\$ 11.4$ trillion (in 2009 dollars) in total R\&D funding, of which $\$ 6.3$ trillion was funded by business enterprises, $\$ 4.5$ trillion by government agencies, and the remaining $\$ 580$ billion from "other" sources, which include universities (and colleges) and nonprofits. The funding has been used to perform $\$ 1.7$ trillion in basic research, $\$ 2.3$ trillion in applied research, and $\$ 6.6$ trillion in process and product development over these 59 years.

"Research and Development" as a type of expenditure, or more correctly investment, ${ }^{44}$ typically includes a variety of activities that do not necessarily have clear boundaries or focus. Given that we are presenting data primarily from the National Science Foundation, we rely on their definitions for R\&D and its components: 45

\footnotetext{
${ }^{44}$ It is obvious to anyone who studies the $R \& D$ process that, for a business, $R \& D$ is an investment in an asset that can generate revenues over two or more accounting periods, not a current expense related to revenue generation in the current accounting period. Yet on financial statements, $R \& D$ is treated as a current expense because R\&D expenditures are mainly invested in human capital, and, in the absence of slavery, a business cannot own human capital (a company's most valuable assets can walk out the door). Hence the particular problem of accounting for R\&D is part of a more general problem of accounting for human capital.

45 These definitions are quoted from National Science Board, Globalization of Science and Engineering Research, National Science Foundation, 2010, p. 9 at http://www.nsf.gov/statistics/nsb1003/definitions.htm. See also Definitions from
} 
Who Invests in the High-Tech Knowledge Base?

$>\mathbf{R} \& D$, also called research and experimental development, comprises creative work undertaken on a systematic basis to increase the stock of knowledge-including knowledge of man, culture, and society-and its use to devise new applications.

$>$ Research is defined as systematic study directed toward fuller scientific knowledge or understanding of the subject studied. Research is classified as either basic or applied according to the objectives of the sponsoring agency.

$>$ Basic research is defined as systematic study directed toward fuller knowledge or understanding of the fundamental aspects of phenomena and of observable facts without specific applications towards processes or products in mind.

$>$ Applied research is defined as systematic study to gain knowledge or understanding necessary to determine the means by which a recognized and specific need may be met.

$>$ Development is defined as systematic applications of knowledge or understanding directed toward the production of useful materials, devices, and systems or methods, including design, development and improvement of prototypes and new processes to meet specific requirements.

As a nation, the United States has committed, and continues to commit, world-leading resources for research and development. Table 1 shows gross expenditure on R\&D (GERD) as a percent of gross domestic product (GDP) for OECD nations and the OECD as a whole for 2000 and $2011 .{ }^{46}$ The United States was well above the OECD average in both 2000 and 2011, and increased GERD from 2.61 to 2.76 over this period. At the same time, however, in 2011 the United States lagged a number of countries that it had led in 2000, including South Korea, Denmark, Germany, Switzerland, and Austria.

In 2011 the United States, with $4.4 \%$ of the world's population, accounted for just under $30 \%$ of the world total R\&D spending, but that was down from 37\% in 2001. Meanwhile a group of Asian nations that includes China, India, Japan, Malaysia, Singapore, South Korea, and Taiwan increased their combined share of global R\&D spending from 25\% in 2001 to $34 \%$ in 2011, with China at 15\% and Japan at $10 \%$. Meanwhile the European Union saw its share of global R\&D fall from $26 \%$ to $22 \%$ over these ten years. ${ }^{47}$

NSF.gov "Definitions of Research and Development: An Annotated Compilation of Official Sources": http://www.nsf.gov/statistics/randdef/start.cfm

46 OECD.StatsExtracts, Main Science and Technology Indicators, GERD as a \% of GDP at http://stats.oecd.org/Index.aspx?DataSetCode=MSTI_PUB

47 From Science and Engineering Indicators Digest, 2014, "Chapter 4. Research and Development: National Trends and International Comparisons," http://www.nsf.gov/statistics/seind14/index.cfm/chapter-4/c4h.htm 
Who Invests in the High-Tech Knowledge Base?

Table 1. Gross Expenditure on R\&D as a Percent of Gross Domestic Product, OECD Countries, 2000 and 2011

\begin{tabular}{|c|c|c|}
\hline Country & 2000 & 2011 \\
\hline Korea & 2.30 & 4.04 \\
\hline Israel & 4.03 & 3.97 \\
\hline Finland & 3.35 & 3.80 \\
\hline Sweden & 4.13 & 3.39 \\
\hline Japan & 3.00 & 3.38 \\
\hline Denmark & 2.39 & 2.98 \\
\hline Germany & 2.47 & 2.89 \\
\hline Switzerland & 2.47 & 2.87 \\
\hline Austria & 1.93 & 2.77 \\
\hline United States & 2.62 & 2.76 \\
\hline Iceland & 2.67 & 2.61 \\
\hline Slovenia & 1.38 & 2.47 \\
\hline Estonia & 0.60 & 2.37 \\
\hline OECD - Total & 2.17 & 2.37 \\
\hline France & 2.15 & 2.25 \\
\hline Belgium & 1.97 & 2.21 \\
\hline Australia & 1.48 & 2.19 \\
\hline Netherlands & 1.94 & 2.03 \\
\hline United Kingdom & 1.79 & 1.78 \\
\hline Canada & 1.87 & 1.74 \\
\hline Norway & 1.59 & 1.65 \\
\hline Czech Republic & 1.17 & 1.64 \\
\hline Ireland & 1.11 & 1.61 \\
\hline Portugal & 0.73 & 1.52 \\
\hline Luxembourg & 1.65 & 1.43 \\
\hline Spain & 0.91 & 1.36 \\
\hline New Zealand & 1.11 & 1.26 \\
\hline Italy & 1.04 & 1.25 \\
\hline Hungary & 0.81 & 1.22 \\
\hline Turkey & 0.48 & 0.86 \\
\hline Poland & 0.64 & 0.76 \\
\hline Slovak Republic & 0.65 & 0.68 \\
\hline Greece & 0.59 & 0.67 \\
\hline Mexico & 0.33 & 0.43 \\
\hline Chile & na & 0.34 \\
\hline
\end{tabular}

Notes:

Figures in 2000 column for Sweden, Denmark, Norway, New Zealand, and Greece are from 2001.

Figure in 2011 column for Switzerland is from 2008 and for Australia is from 2010.

How have the types of R\&D that the United States does changed over time? Figure 7 tracks the growth of spending in Basic Research, Applied Research, and Development from 1953 through 2011, in 2009 dollars. Over these 59 years, total real spending has increased 12 times, from \$34 billion in 1953 to $\$ 411$ billion in 2011, a period over which the population of the United States doubled. On a per capita basis, therefore, in 2011 the United States spent on R\&D in inflationadjusted dollars about six times per capita the amount that it spent at the time of the Korean War and on the eve of the Cold War. Figure 8 shows the same data on Basic Research, Applied Research, and Development as percentage shares of the total. 
Figure 7. R\&D expenditures in the United States, Basic Research, Applied Research, and Development components, 1953-2011

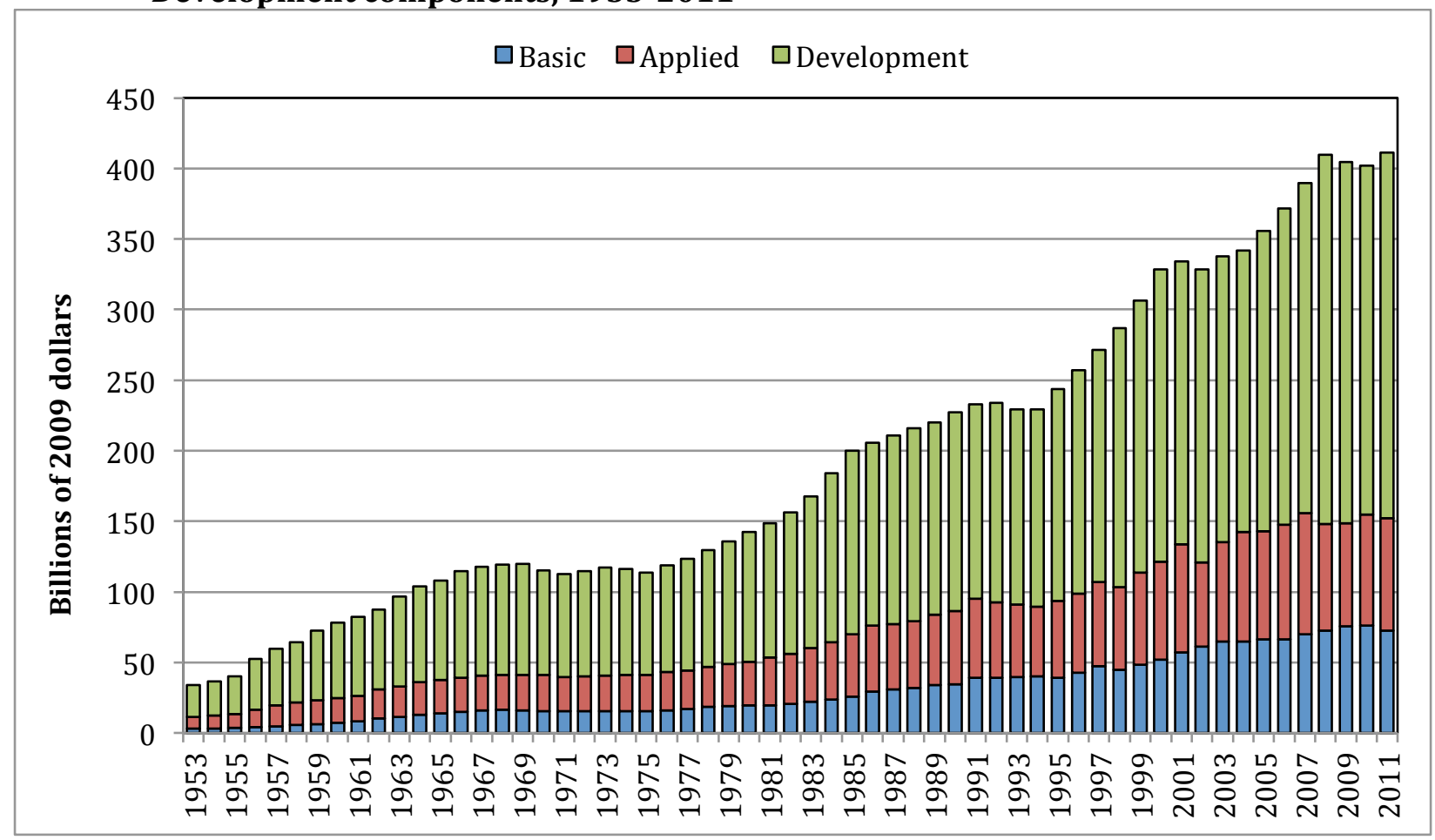

Sources: NSF Tables 4-7, 4-8, and 4-9.

Figure 8. Percentages of R\&D Expenditures in the United States that were Basic Research, Applied Research, and Development, 1953-2011

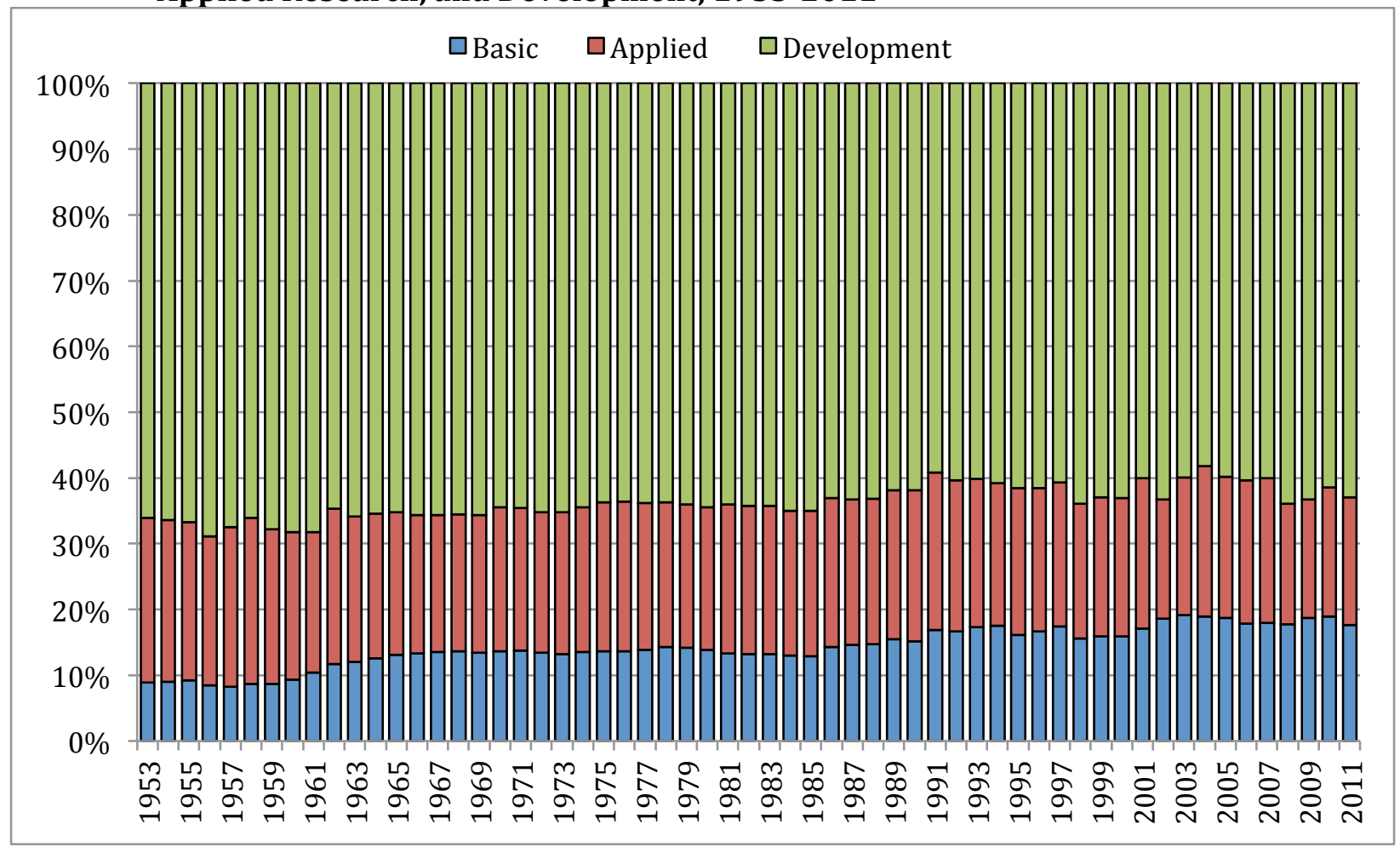

Sources: NSF Tables 4-7, 4-8, and 4-9. 
Development has always constituted the majority of R\&D spending, ranging between $58 \%$ in 2003 and $69 \%$ in 1956. As long run trends over the six decades displayed in Figure 8, Applied Research has become a slightly smaller share of the total while the Basic Research share has increased substantially. Comparing annual averages for the five-year periods 1953-57 and 2007-2011, Basic Research rose from $8.8 \%$ to $18.3 \%$ of the total, while Applied Research fell from $24.1 \%$ to $20.0 \%$ and Development fell from $67.1 \%$ to $61.8 \%$.

As we saw in the previous section of this report, the "linear model" of R\&D assumes that innovations result from a knowledge flow that unfolds sequentially through three basic activities categorized as Basic Research, Applied Research, and (Product or Process) Development. The result of the $R \& D$ process is a new or upgraded product that is sold on a market in which the innovator enjoys a superior competitive position. Given that different types of organizations - government agencies, business enterprises, universities, and nonprofits - are involved in the R\&D process, an assumption (perhaps implicit) of a linear model of R\&D could be that Government funds Basic Research and Applied Research, Universities and Nonprofits perform Basic Research and Applied Research, and Business funds and performs Development.

In fact, however, as we shall see in this section, Government funds and performs all three activities (Basic Research, Applied Research, and Development). The same is true for Business, Universities, and Nonprofits. Where variation exists, it is in the relative proportions of R\&D funded and performed by each actor. Moreover, the linear model fails to capture evidence of organizational learning. As we emphasized at the beginning of this report, the essence of the innovation process is that it is both collective and cumulative. It should be asked how and to what extent the activity of $\mathrm{R} \& \mathrm{D}$ is better described by an "interactive model". How, for example, does Basic Research performed by Business influence Applied Research? How clear is the distinction between the activities? And how might the presence of Government-sponsored or partnered research influence, enhance, or complicate those distinctions?

More generally, we can think of the R\&D process as a proxy for the collective and cumulative learning through which a high-tech knowledge base forms. Besides involving different types of organizations that fund and perform different $R \& D$ activities, we can expect the interactive $R \& D$ process to vary across different types of high-tech sectors such as ICT, biotech, and cleantech, and to change over time. Indeed over the span of six decades that we are considering, the R\&D process has transformed from a national to a global system, particularly in an industry such as wireless communications in which new-generation systems standards are set in an international, not domestic, context. If the interactive R\&D process was once part of a "national innovation system", it may now be part of a "global innovation system".

Table 2 shows the division of R\&D funding and performance across the four types of organizations and the three types of R\&D functions for the whole 59-year span of current data. Two (approximately) equal periods, 1953-1982 and 1983-2011 are shown. Overall, Table 2 shows that, as one would expect, in both periods Government and Business fund awhile Business and Universities perform.

In the earlier period Government funded almost three-quarters of Basic Research and just over half of both Applied Research and Development. Almost all of the remaining shares of Applied Research and Development funding were borne by Business, as well as most of the remaining share of Basic Research. Universities and Nonprofits each funded the remaining balance at $5 \%$ for Basic Research each. During the second period, a considerable share of Applied Research funding and an even larger share of Development funding appeared to shift from Government to Business. Business 
Who Invests in the High-Tech Knowledge Base?

funded several percentage points more of Basic Research, with Universities and Nonprofits each approximately doubling their shares.

In terms of the performance of $R \& D$, in the earlier period Universities did almost two-thirds of all Basic Research and Business almost one-fifth. Business was the predominant performer of both Applied Research and Development, and indeed did the vast majority of the latter, with Government doing most of the rest. In the later period the shares of the four organizations across all three R\&D functions are very similar to the earlier period, with Business, Universities, and Nonprofits all having shares that are at least equal to or in the range of one to six percentage points greater than in the earlier period. These small shifts in shares of performance by Business, Universities, and Nonprofits add up to a reduced role of Government in performing Basic Research and Applied Research in the later period along, with a more modest decline in its share of performing Development.

Table 2. Funding and Performance of R\&D, by Organization and R\&D Function, United States, 1953-2011

Percent except for Total 2009\$ for 1953-1982 and 1983-2011

\begin{tabular}{|c|c|c|c|c|c|c|}
\hline & \multicolumn{3}{|c|}{ Funding } & \multicolumn{3}{|c|}{ Performing } \\
\hline & Basic & Applied & Devel. & Basic & Applied & Devel. \\
\hline \multicolumn{7}{|l|}{$1953-1982$} \\
\hline $\begin{array}{l}\text { Total, billions of } \\
2009 \$\end{array}$ & 385 & 672 & 1,977 & 385 & 672 & 1,977 \\
\hline Government & 73 & 51 & 52 & 15 & 21 & 12 \\
\hline Business & 17 & 45 & 47 & 18 & 61 & 84 \\
\hline Universities & 5 & 2 & 0 & 59 & 13 & 2 \\
\hline Nonprofits & 5 & 2 & 0 & 9 & 5 & 2 \\
\hline \multicolumn{7}{|l|}{ 1983-2011 } \\
\hline $\begin{array}{l}\text { Total, billions of } \\
2009 \$\end{array}$ & 1,413 & 1,774 & 5,150 & 1,413 & 1,774 & 5,150 \\
\hline Government & 61 & 36 & 25 & 8 & 11 & 8 \\
\hline Business & 20 & 58 & 75 & 20 & 67 & 88 \\
\hline Universities & 10 & 3 & 0 & 59 & 16 & 2 \\
\hline Nonprofits & 9 & 3 & 1 & 12 & 6 & 2 \\
\hline
\end{tabular}

Sources: NSF Tables 4-3, 4-4, 4-5, 4-6, 4-7, 4-8, 4-9.

In the next sections, we begin to probe more deeply into available data to describe changes in U.S. patterns of funding and performance of $R \& D$ in more detail. We begin with an overview of Basic Research, Applied Research, and Development activities. In several instances we provide historical context that helps explain the changes reflected in the data. We then examine additional data provided on Government, Business, and University R\&D activities to describe in more detail some of the major organizations conducting the largest proportions of R\&D currently. In many cases, it is these organizations that, given their mandates, strategic choices, or interests, and their decisions to conduct R\&D on their own or with other organizations, exercise great influence on the focus and content of U.S. science and technology activities. Together, these leading organizations help determine where the frontier of knowledge will be in the future and what the yield of innovation that raises economic productivity will be. 


\section{b) Basic Research}

From 2007 through 2011, funding for Basic Research averaged \$73.5 billion in 2009 dollars per annum. As can be seen in Figure 9, in 2011 Government funded 58\% of all Basic Research. In the late 1950s and early 1960s, the share of Government-funded Basic Research rose substantially, and then leveled off from 1965. The rising share of Business-funded Basic Research from 1979 (and the mirror-image decline in the share of Government-funded Basic Research) is probably related to the burst in venture-backed high-tech startups occurring around that time, especially in biotech. The year-to-year fluctuations in the shares of Business and Government as funders of Basic Research may also be the result of volatility in both the number of high-tech startups and their survival. The gradual rise in the combined share of University and Nonprofit funding of Basic Research from about $11 \%$ in the early 1980 s to $22 \%$ is partially related to the growth of NIH funding of life sciences research. 48

Figure 9. Basic Research Expenditures by Funding Source, as Percent of Total, 1953-2011

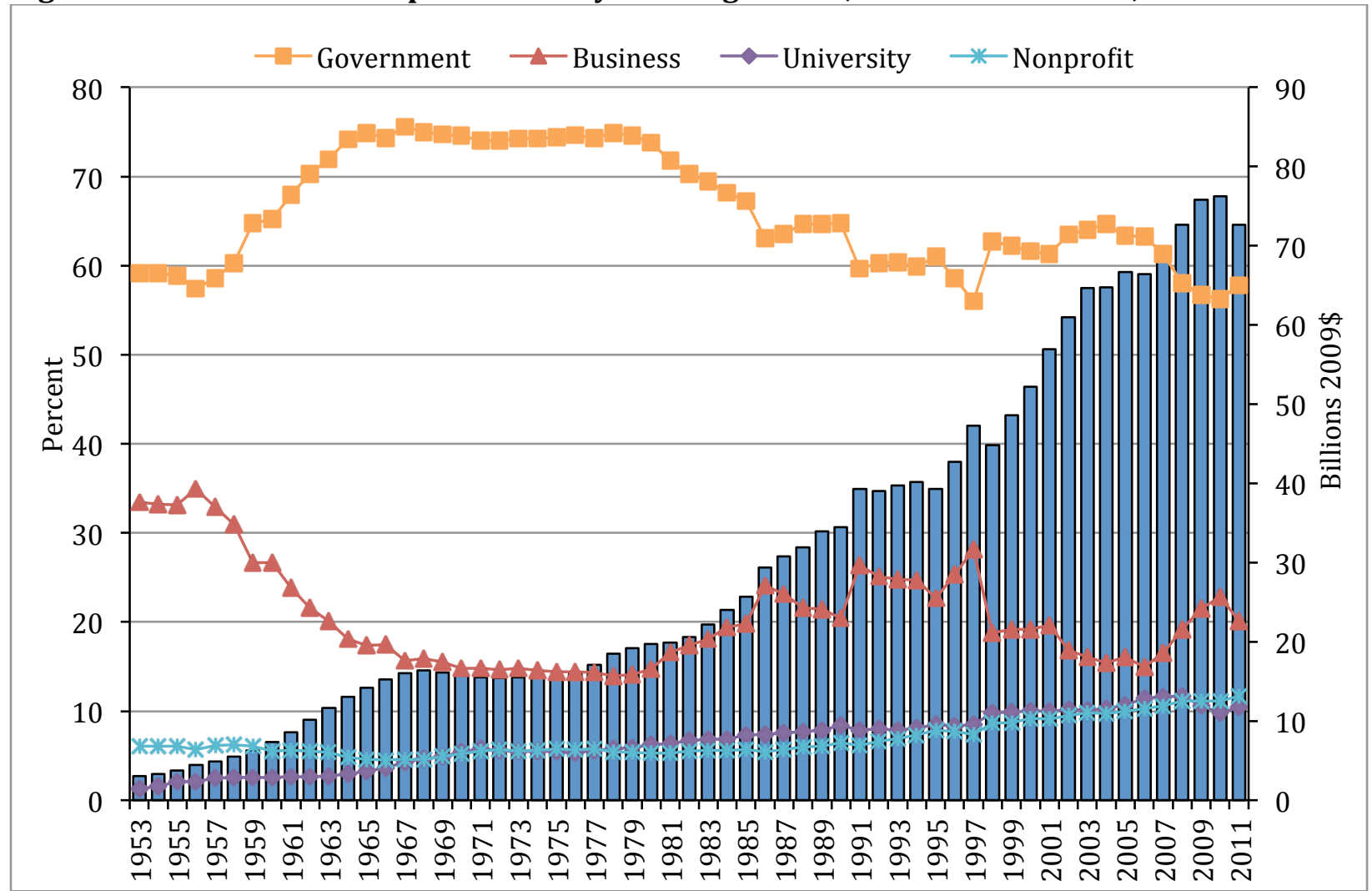

Source: NSF, appendix table 4-7, "U.S. basic research expenditures, by source of funds and performing sector: 19532011."

Figure 10 shows the division of labor in the performance of Basic Research. In the late 1950s, as a result of the types of commitments to research made in response to the Soviet Union's launch of the

48 We review data for Universities in more depth below. NSF data for Nonprofits is more limited. A 2001 infobrief, however, showed that the top 10 leading Nonprofits included several medical research centers, defense contractors, and SEMATECH, a Business consortium focused on technology roadmapping for the semiconductor industry. Similar to Universities, leading Nonprofits receive much of their funding from Government agencies, primarily the DHHS and DoD. As such, a high proportion of activity would include biotechnology Basic Research, with a focus on life science. See Mary Burke, (Feb 15 2001), "NSF Databrief: Nonprofit Sector's R\&D Grows Over Past Quarter Century," at http://www.nsf.gov/statistics/databrf/sdb01318.htm 
Who Invests in the High-Tech Knowledge Base?

Sputnik satellite, Universities surpassed Business as the major location for the performance of Basic Research. The University share increased to over 50\% in 1972, but then stagnated until 1998 when huge increases in NIH funding were directed toward Universities. As with the funding of Basic Research, Business historically conducted a larger share of the nation's Basic Research than it does today. Comparing Figure 8 above with Figure 18 below, Business-funded Basic Research is typically performed by Business itself.

Figure 10. Performance of Basic Research by Organization, as Percent of Total, 1953-2011

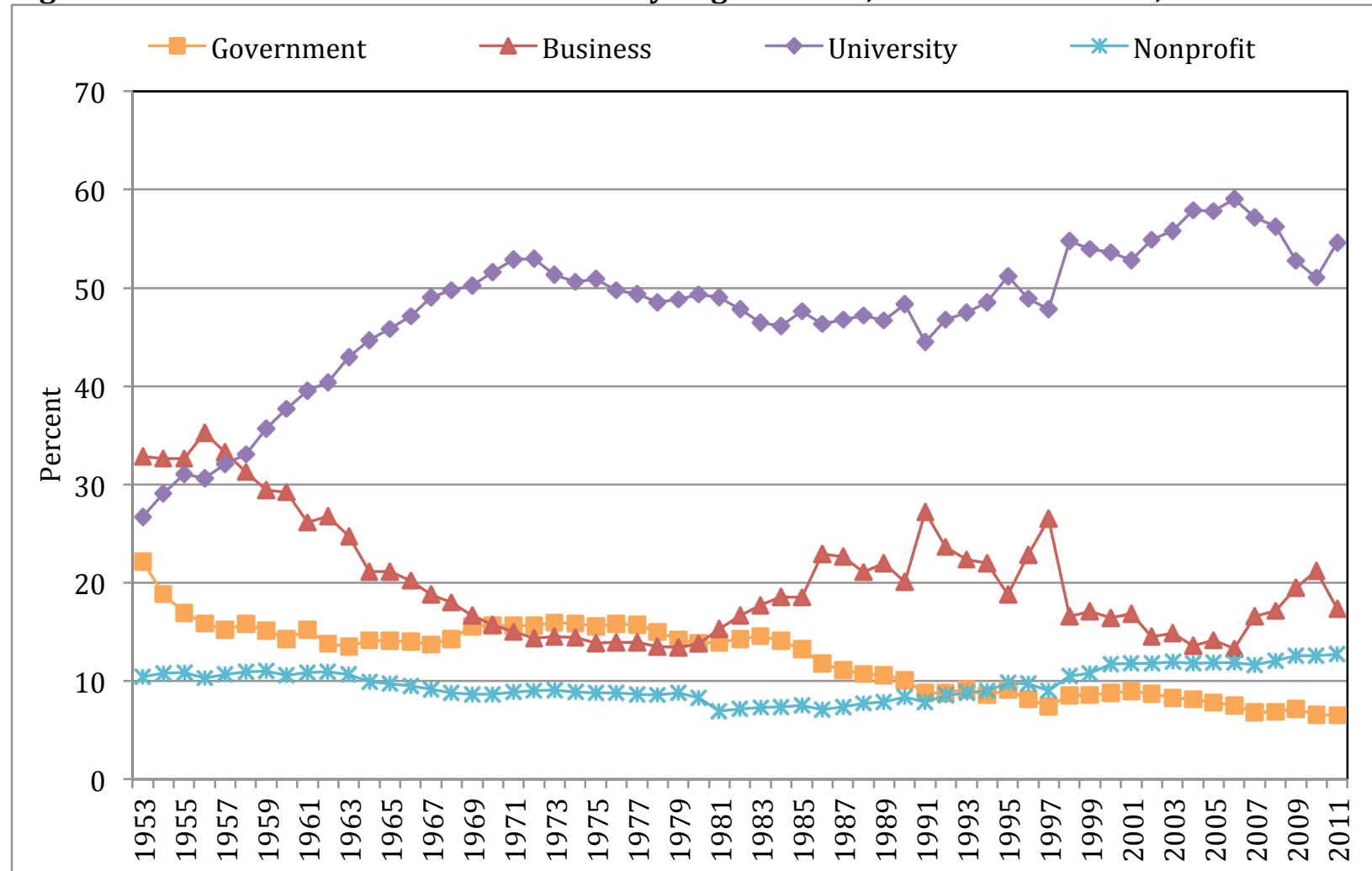

Source: NSF, appendix table 4-3, "U.S. basic research expenditures, by performing sector and source of funds: 1953-2011"

\section{c) Applied Research}

Figure 11 shows the changes in the funding of Applied Research from 1953 to 2011. From 1953 to 1965 Government funded between 55\% and 61\% of applied research, but then the Government share of funding began a long decline as the Business share increased. The shift was driven by the microelectronics revolution, explained in greater detail below. In short, ICT companies were engaged in research with a view to finding commercial applications for digital technologies that had begun to mature. Since 2001, however, the Business share of funding has been volatile, with a discernible downward trend, with Government funding clearly taking the place of Business funding, within a context in which overall Applied Research funding was on the rise. Whether the 2011 dip in total Applied Research funding bears any significance as a new trend awaits release of more recent data. 
Figure 11. Applied Research Expenditures by Source, Percent of Total, 1953-2011

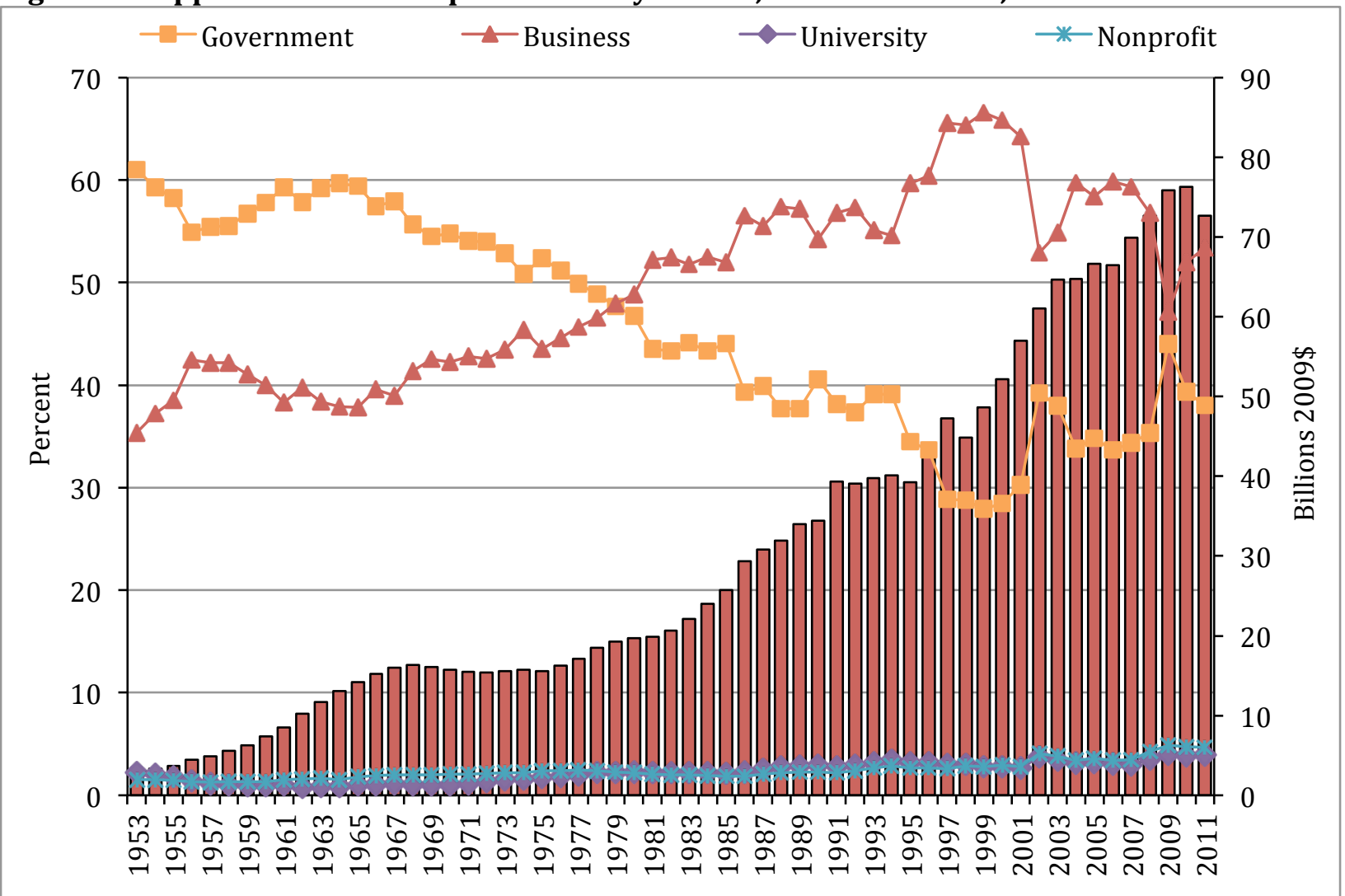

Source: NSF, Appendix table 4-8, "U.S. applied research expenditures, by source of funds and performing sector: 19532011."

Figure 12 shows the performance side of Applied Research. In the first decade of the $21^{\text {st }}$ century, the Business share of the performance of Applied Research remained higher than its share of funding $-60 \%$ as compared with $53 \%$ in 2011 . The gap leaves a significant portion of the Applied Research that took place within Business to be funded by the Government, shown in Figure 10, above. Over the course of the 2000s, the gap has averaged approximately $8 \%$. But during the 2000s Business funding for Applied Research experienced "boom and bust" cycles, with sharp declines occurring in the two economic recessions during the 2000s. Between 2000 and 2001 Business funding fell in real terms from $\$ 54$ billion to $\$ 35$ billion (a 35\% decline). It then rose to $\$ 60$ billion by 2007 and crashed again to $\$ 43$ billion in 2009 (a 28\% decline). 
Figure 12. Performance of Applied Research by Organization, Percent of Total, 1953-2011

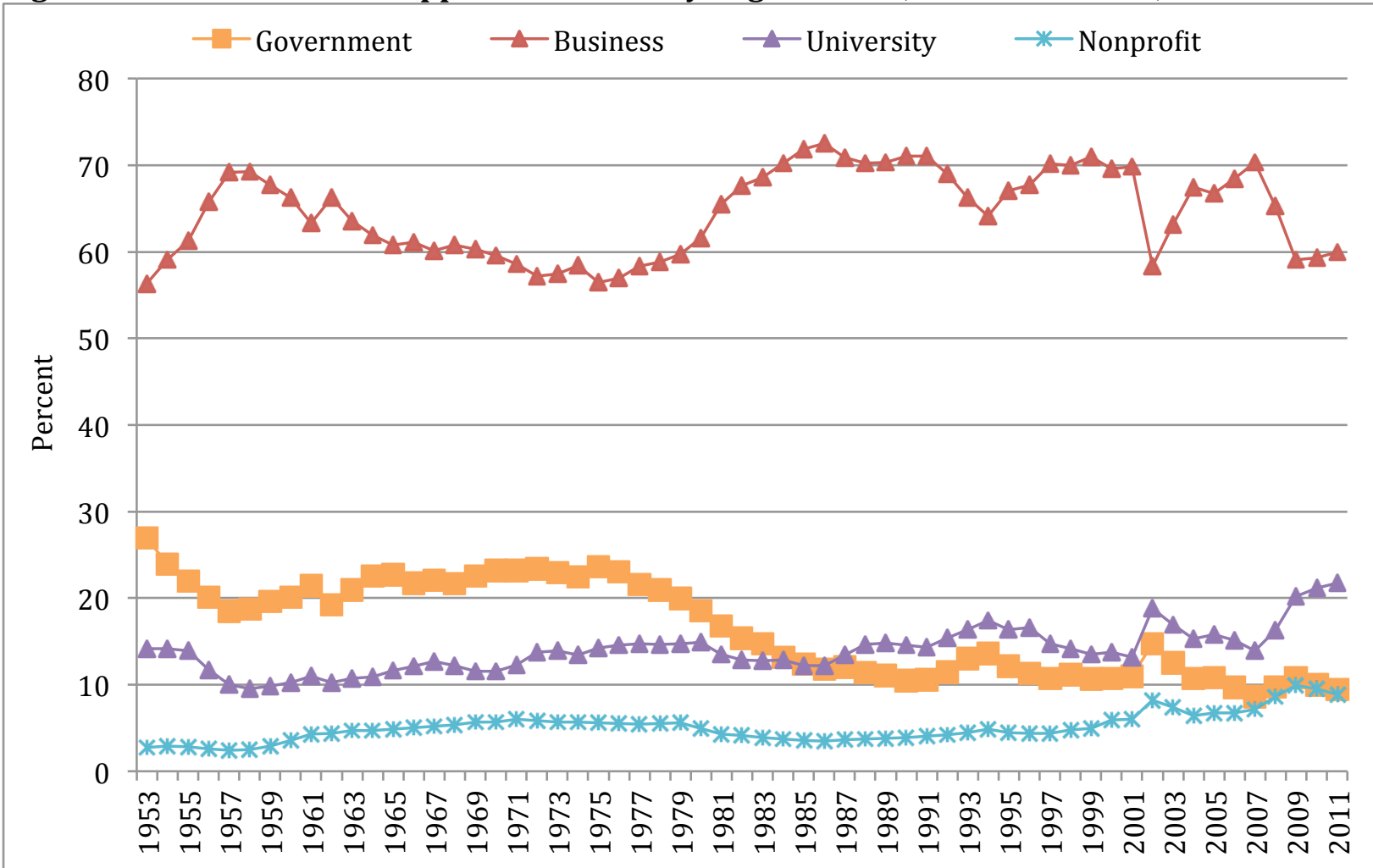

Source: Author's calculations. NSF, Appendix table 4-4, "U.S. applied research expenditures, by performing sector and source of funds: 1953-2011."

\section{d) Development}

The shift in the funding of Development over the last six decades was dramatic. It is even more pronounced than the shift in Basic Research funding shown above. Figure 13 appears to show Government and Business switching their Development funding roles completely, with high levels of Business spending on Development occurring while Government levels declined over time. The moment of this inversion is around 1974, which is followed by a decade of relative stability in cost "sharing", with the Business share of Development funding moving sharply until 2001 when it flattens out at around $80 \%$. The downward trend in the share of Government funding began in 1965 when, as a prime example, integrated circuits transitioned from being produced almost exclusively for military purposes to being produced for commercial purposes as the cost of manufacturing integrated circuits fell significantly. Between 2008 and 2011 the share of funding provided by Business averaged 77\%. These changes were driven by the importance of Cold War Development spending for military purposes and space exploration in the earlier period, and the rising importance of non-military related "New Economy" companies since the last half of the 1970s.

Figure 14, which shows the performance of Development presents a very different picture than Figure 13 on the funding of Development. The share of Development that Business performed was relatively stable over the six decades because during the earlier period when Government was funding the bulk of Development, Business was performing it for the Cold War and Space programs. In contrast, since the late 1970s Business had both funded and performed Development on a more equivalent basis. 
Who Invests in the High-Tech Knowledge Base?

Figure 13. Development Expenditures by Funding Source, Percent of Total, 1953-2011

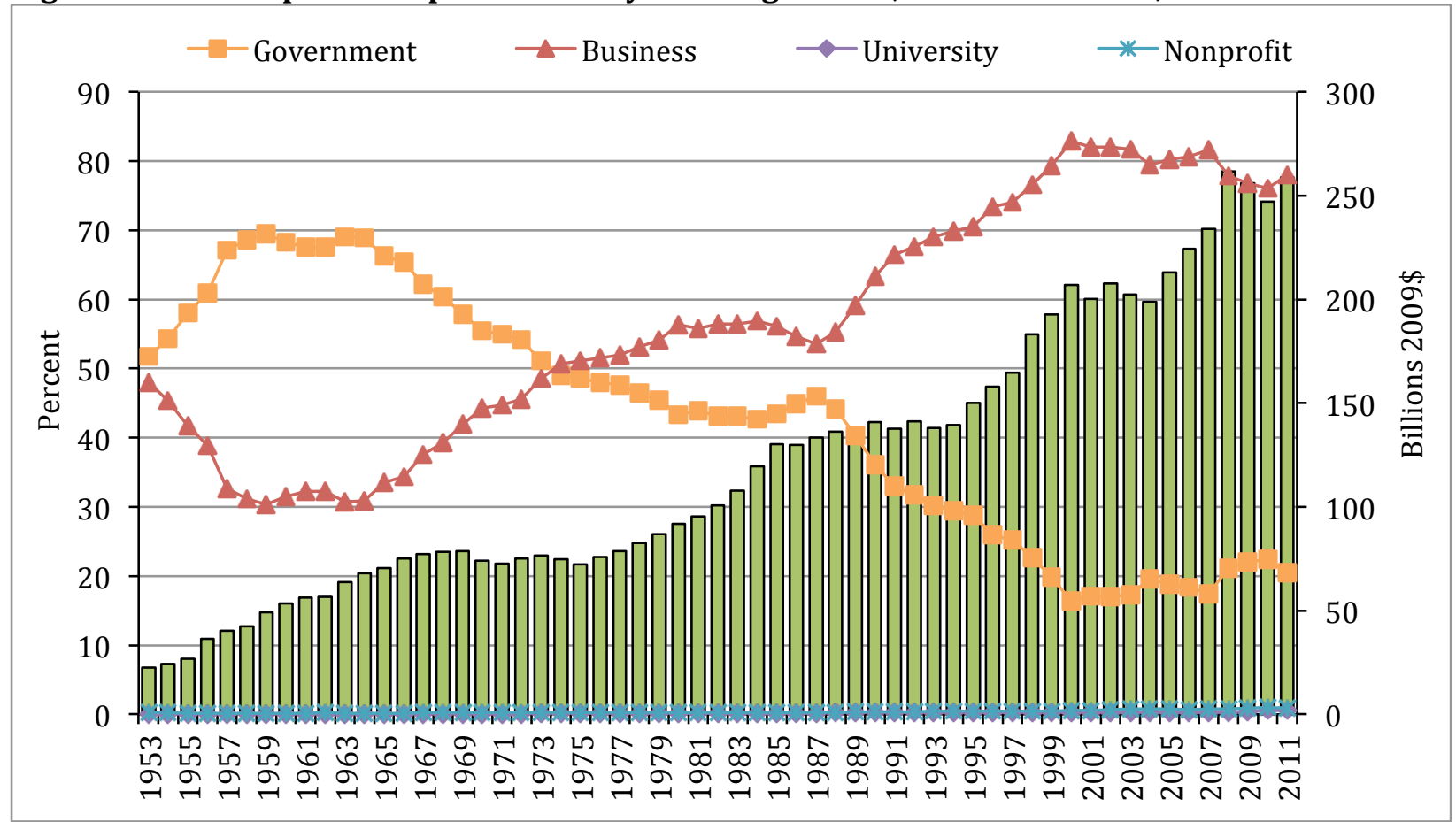

Source: NSF Table 4-9, “U.S. development expenditures, by source of funds and performing sector: 1953-2011.”

Figure 14. Performance of Development by Organization, Percent of Total, 1953-2011

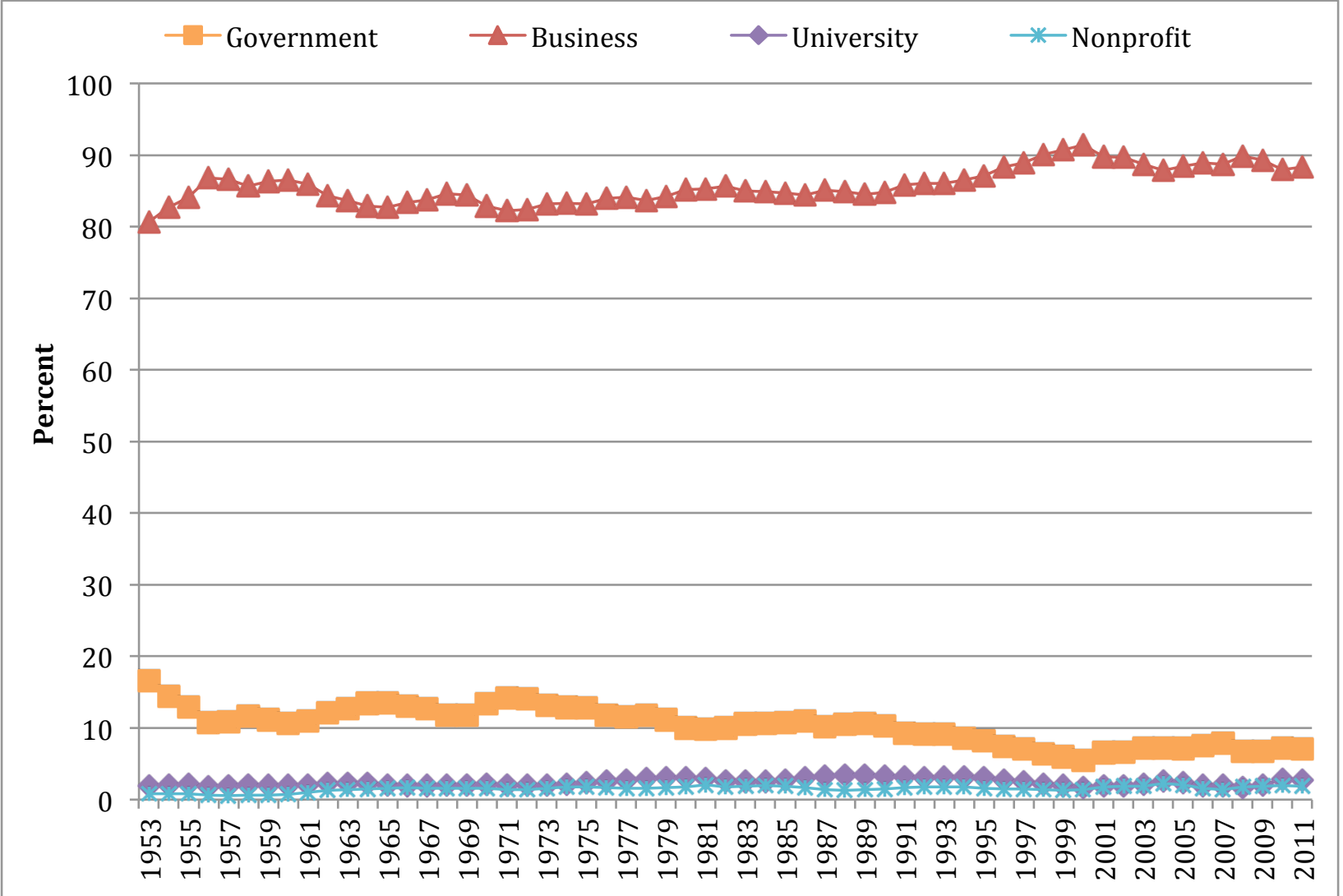

Source: NSF, Table 4-5, “U.S. development expenditures, by performing sector and source of funds: 1953-2011." 


\section{e) Government Support for R\&D}

Government support for R\&D is substantial. Figure 15 shows that Government funding for R\&D has grown in real terms from $\$ 18$ billion in 1953 to over $\$ 120$ billion in 2011 , an average rate of increase of about 4\%. R\&D funded by the government increased substantially from 1953 to 1963, and indeed was already rising rapidly between 1953 and 1957, before the successful launch of the Sputnik satellite led to a rapid increase in government spending on space and defense programs. From 1957 to 2002, government funded R\&D performed by Business generally declined, particularly in the period 1987-2000, which coincides with the collapse of the Soviet Union and hence the end of the Cold War rationale for military spending. Beginning in the year 2000, however, the share of government funded R\&D performed by Business has again trended upward. The reason for the $6 \%$ shift in the performance of Government-funded R\&D from Universities to Business that occurred in 2008-2009 before reverting back needs to be determined. One possible explanation is that the change reflects reductions in government funding for Basic and Applied research (shown in Figures 9 and 11, above), accompanied by increased funding in those areas by Business between 2006 and 2011.

Figure 15. Government Funding Support for R\&D by Performing Sector, 1953-2011

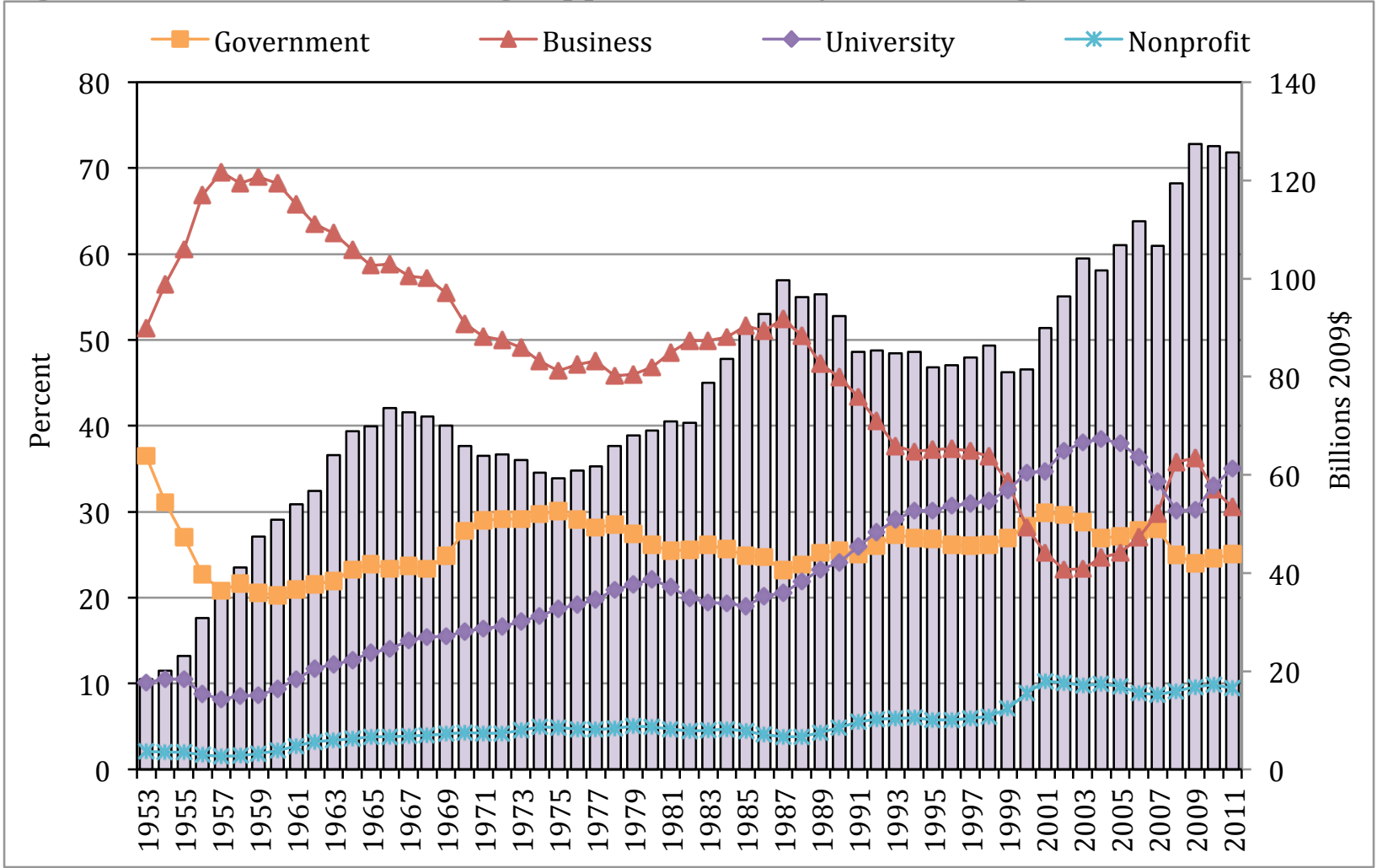

Source: NSF Appendix table 4-6 “U.S. R\&D expenditures, by source of funds and performing sector: 1953-2011"

Also evident is the long-term decline in Government funded, Business-performed R\&D. Performing as much as 70\% of Government-funded R\&D in 1957, Business performed just $23 \%$ in 2002 and $33 \%$ in 2011. In contrast is the expanded role of Universities, which performed just $10 \%$ of Government-funded research in 1953 but 35\% in 2011. Through much of the 2000s Universities performed more Government-funded research than Business or Government itself. Much of the life sciences research funded by the NIH is performed in Universities, adding to the general trend from the late 1980s of more high-tech research being done in Universities rather than Business. The 
University share of performance of Government-funded R\&D peaks in 2004, which is when the late 1990s-early 2000s doubling of the NIH budget was completed. The NIH, shown in Figure 17 below, currently provides the lion's share of Basic Research funds on behalf of the Government for the United States (appearing as the category "Health").

Government expenditures can also be described by budget function, shown in Figure 16. In short, budget functions show how Government appropriations for R\&D are distributed across a broad set of objectives. Total funding levels do not perfectly match with other tables presented in this report. ${ }^{49}$ Despite the presence of 18 major categories of spending, just six represent the majority of funds that are distributed each year. Defense R\&D is by far the largest category of spending historically, making up nearly $90 \%$ of funding in the 1950 s, and averaging $60 \%$ over the whole period of 1955-2014 (amounting to over $\$ 3$ trillion in inflation-adjusted funds). By comparison, Health spending has averaged $13 \%$ (or $\$ 800$ billion of total spending) and Space Flight $11 \%$ ( $\$ 500$ billion) over the same period.

\section{Figure 16. Government R\&D Allocation by Budget Function, 1955-2014}

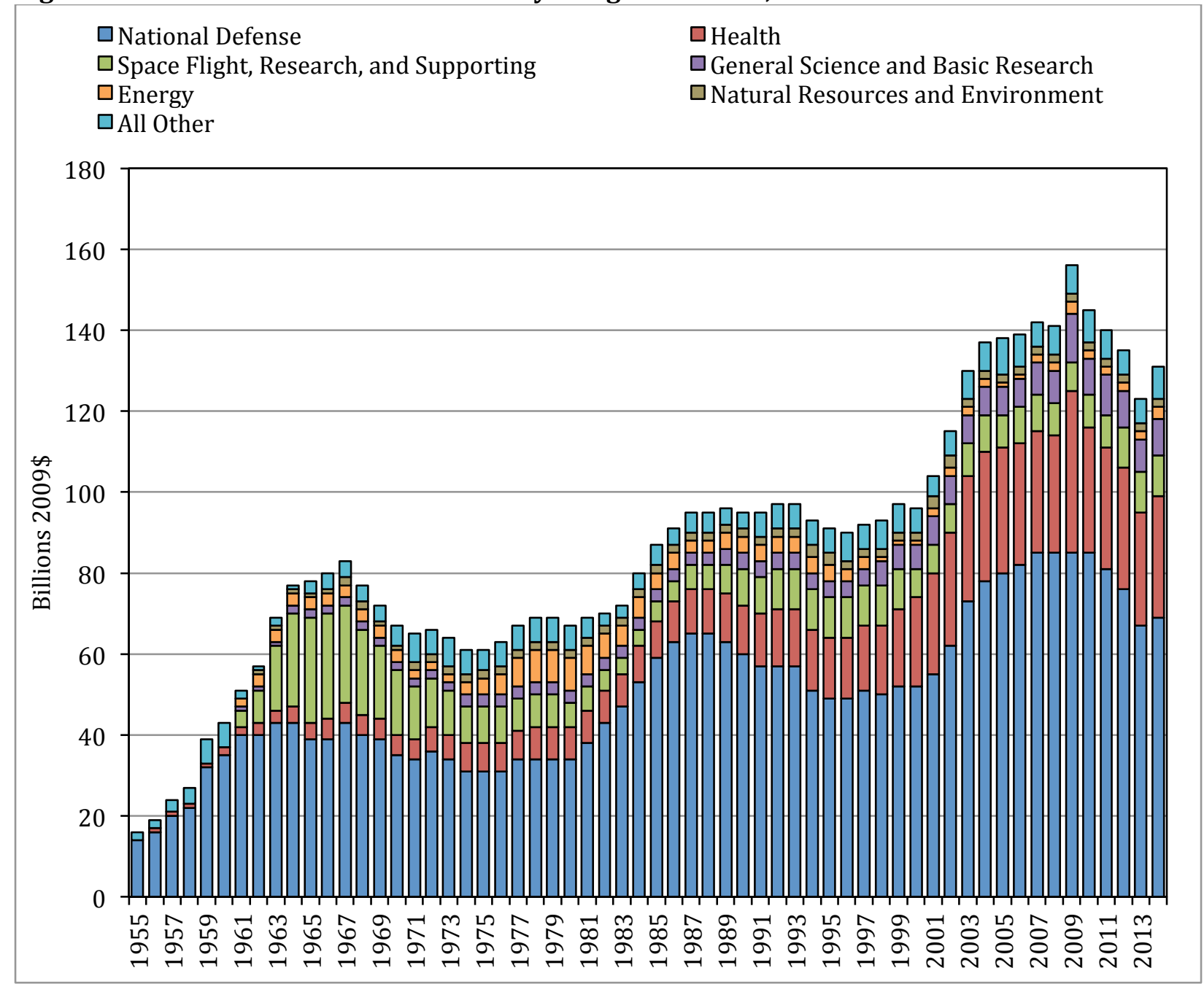

Source: NSF, Table 24, "Federal funding for R\&D and basic research, by budget function: FYs 1955-2014."

49 "Because planning and actual spending are different steps, the reported statistics on R\&D in obligations typically differ from the corresponding items in budget authority terms." See NSF S\&E Digest 2014, 4-31-4-34, At http://www.nsf.gov/statistics/seind14/content/chapter-4/chapter-4.pdf 
The proportion of Government funding by budget function that is driven into Basic Research is shown in Figure 17. Virtually none of the funding conducted for National Defense is for Basic Research. While support for National Defense rose overall between 1978 and 2014, only 3\% of those funds, on average, were allocated to Basic Research. That is because most National Defense research is mainly focused on Development of products for the military.

Figure 17. Federal Funding for Basic Research by Budget Function 1978-2014

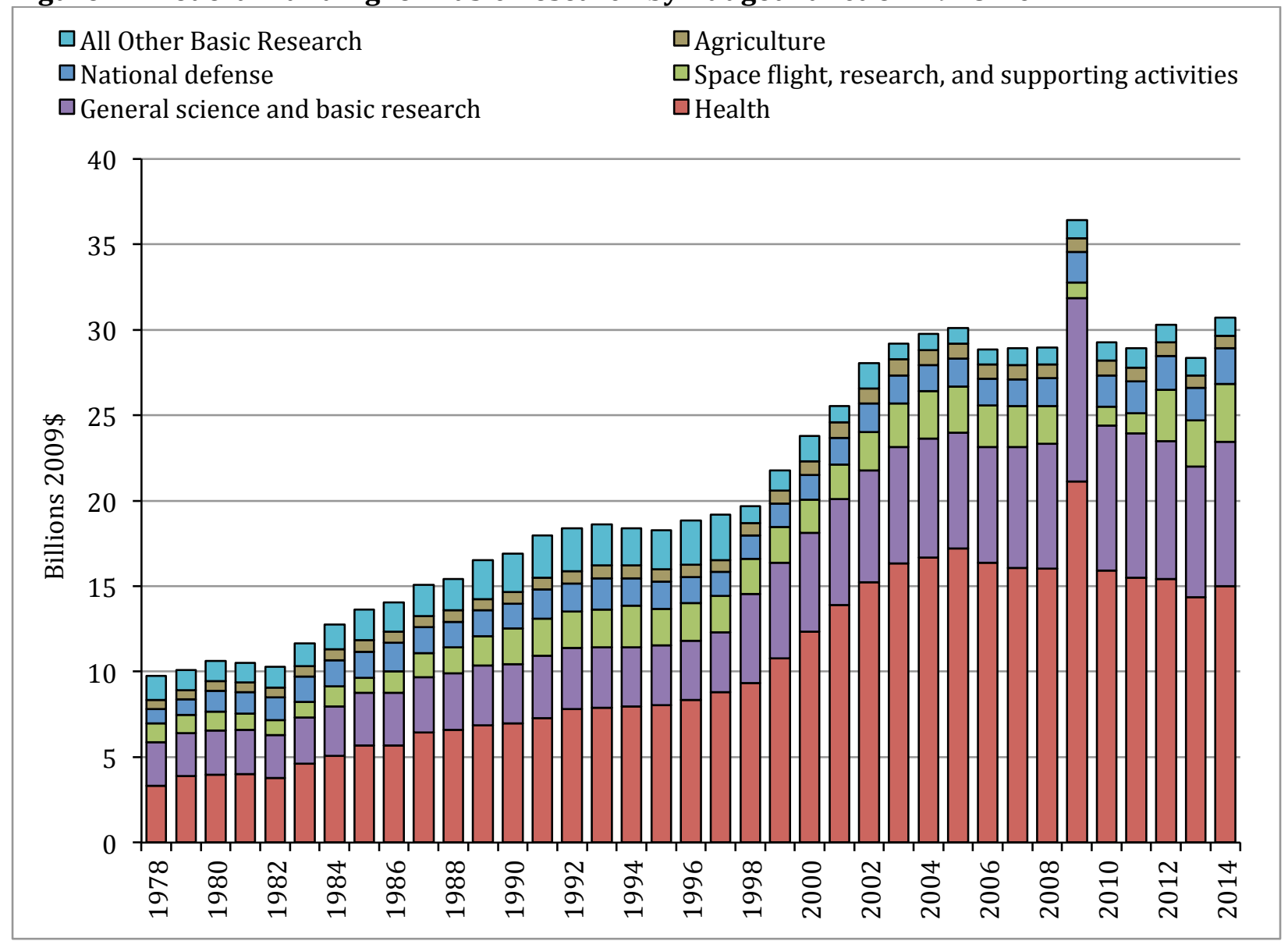

Source: NSF, Table 24, "Federal funding for R\&D and basic research, by budget function: FYs 1955-2014."

The low levels of Basic Research spending for National Defense stand in contrast to the high outlays of Basic Research found for Health ( $\$ 12$ billion in 2011) and General Science ( $\$ 8$ billion in 2011). Such spending is several times the amount of Basic Research for National Defense, which was \$2 billion in 2011. Given such low levels of Basic Research, a linear model of R\&D might predict that the United States will lose military superiority over the long-term by failing to fund large amounts of Basic Research relevant to National Defense needs. Such has not been the case over the last several decades, and we suggest some reasons below in our discussion of DARPA.

Expressed in percent terms, high concentrations of Basic Research funding are found in nondefense categories such as Health (54\%), Agriculture (45\%), General Science (93\%) and Education, Training, and Employment (32\%). Basic Research in Space Flight was an important category through much of the 1980s and 1990s, but the official end of the NASA shuttle program in 2011 is 
the beginning of a transition toward Business-led space exploration and commerce, led by companies such as the startup Space-X, founded in 2002.

Most all Government support for R\&D is distributed through just six Government agencies, shown in Figure 18. These top six agencies distributed 95\% of R\&D funds between 1990 and 2013. Most of the agencies dominating the distribution of R\&D funds were either formed or created following the World War II era. The Department of Energy (DoE), created in 1977 out of the Manhattan Project (1942) and the Atomic Energy Commission (1946), is the youngest of these major R\&D agencies. As we saw in Section 2, the National Science Foundation (NSF) was conceived in 1945 but first funded in 1950, while the National Aeronautics Space Agency (NASA) was organized in 1958 and evolved out of the National Advisory Committee for Aeronautics (NACA), founded in 1915. Both the Department of Defense (DoD) and Department of Health and Human Services (DHHS) have histories that reach back to the $18^{\text {th }}$ century. The DoD in its current incarnation was organized in 1949, distributing its funding through the military branches of the Army, Navy, and Air Force. The DHHS as presently named was organized in 1979, having been the Department of Health, Education, and Welfare since 1953. As we also discussed in Section 2, the National Institutes of Health (NIH) was created in 1948 as an organization of several institutes, while the original National Institute of Health was set up in 1930. The origin of the National Institute of Health was in a Government public-health research lab founded in 1887.

Figure 18. Federal Outlays for Research and Development, by Agency, 1990-2013

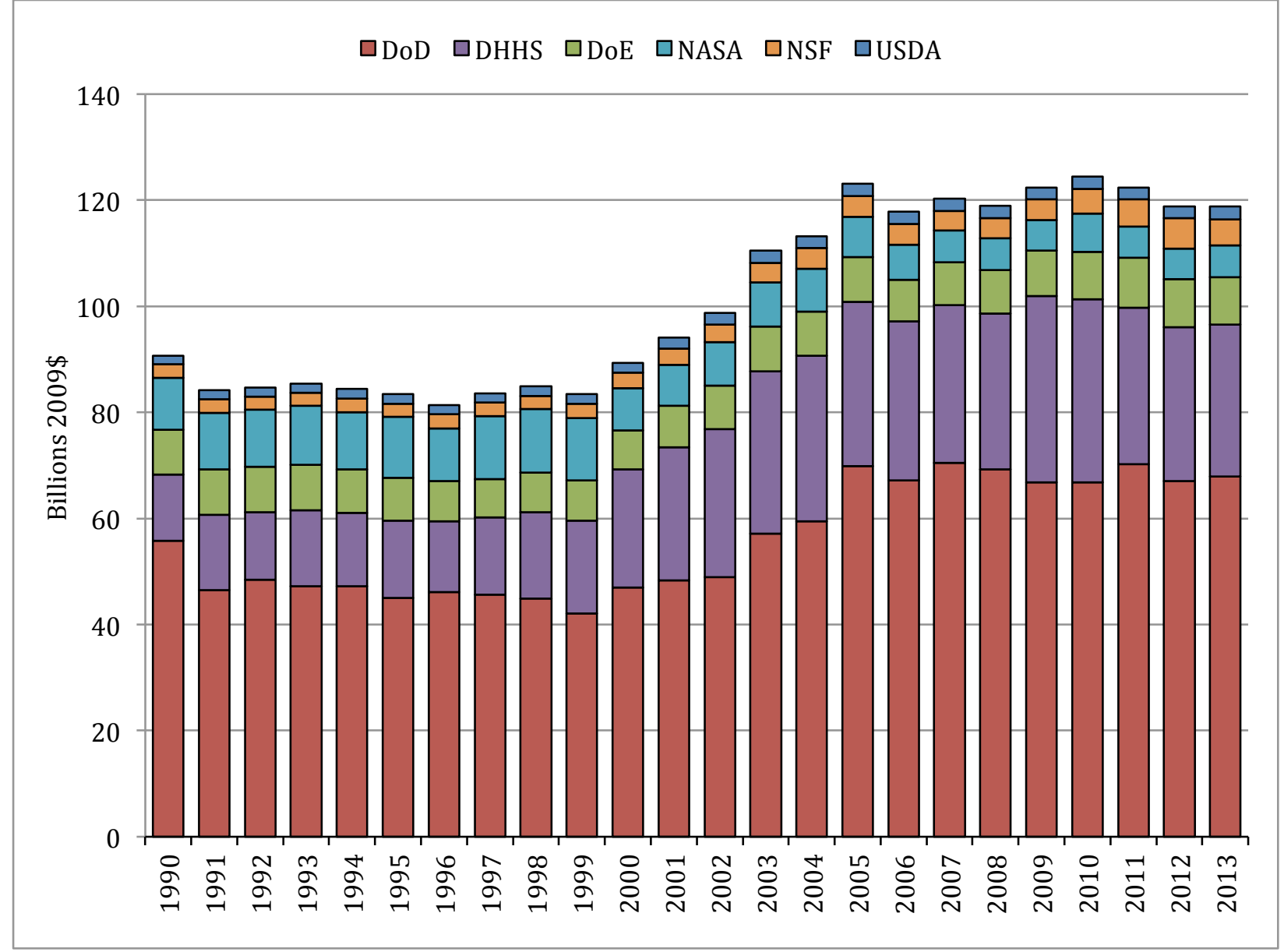

Sources: Data for 2012 and 2013 are preliminary. For years 1990-2002, NSF tables 97, 109. For 2003-2013 tables 98, and 110, "Federal outlays for research and development, by agency." 
Who Invests in the High-Tech Knowledge Base?

Almost the entirety of R\&D funding provided through the DHHS is appropriated to the NIH, the Government's largest non-defense related R\&D organization. NIH funding averaging $\$ 30.6$ billion from 2010 through 2013 exceeded allocations for each branch of the military. The majority of DoD funding is channeled through the Navy.

The remaining 5\% of R\&D expenditures are split between about 30 other Government agencies, led by the Departments of Commerce, Transportation, Interior, Homeland Security, Environmental Protection, and Veterans Affairs. The Department of Homeland Security was created shortly after the terrorist attacks of September 11, 2001, opening with annual budgets of close to $\$ 2$ billion in 2006 before declining to about $\$ 700$ million in 2009 .

The newest government agency with significant R\&D funds, the Advanced Research Projects Agency Energy (ARPA-e), is expected to contribute to the growth of a clean technology industry as a major new economic frontier. Authorized in 2007 and first funded by the 2009 American Recovery and Reinvestment Act, ARPA-e attempts to apply the organizational strengths of the DoD's DARPA to the need for energy innovation. ${ }^{50}$ DARPA, organized in 1958 in response to Sputnik, has contributed to a number of innovations despite a small staff of about 100 and budgets around $\$ 3$ billion. ${ }^{51}$ Notwithstanding association with top-secret exotic technologies (such as stealth aircraft), the successes of DARPA were built not on a linear model of closed clandestine research, but on open networks that leveraged expertise from multiple sources around the country. DARPA recruits its program managers from Business, Universities, or other sources for short spans of three to five years. The program managers act as experts that channel DARPA funding into technology development programs with greatest potential for mission-oriented defense applications. ARPA-e follows a similar model, recruiting experts on a short-term basis to identify and direct funding into disruptive energy innovations that span a wide-range of areas that include energy generation, energy management, and transportation technologies.

Like ARPA-e, DARPA's present funding levels are less than the Department of Veterans Affairs, and place it among those agencies that disperse the remaining $5 \%$ of Government R\&D funds. But both ARPA-e and DARPA have missions to identify and fund disruptive technologies that will likely have far-reaching impacts far beyond those stated in mission or project goals. A critical difference between ARPA-e and DARPA, however, is that most ARPA-e funded technologies will not benefit from the sort of research contract plus procurement policies that proved effective at reducing the cost and risk of developing new technologies such as the transistor, until such time that it could be cost-effectively mass produced for a commercial market. Instead, many of the inventions emerging from ARPA-e support will enter into a globally competitive energy marketplace with complex regulatory and competitive challenges. ${ }^{52}$

\footnotetext{
50 For an explanation of how the "DARPA" model is applied to energy problems, see Erica Fuchs, "The Road to a New Energy System: Cloning DARPA Successfully” Issues in Science and Technology, Fall 2009: 65-70.

51 Erica Fuchs, "Rethinking the Role of the State in Technology Development: DARPA and the Case for Embedded Network Governance," Research Policy, 39, 9. 2010: 1133-1147.

52 In the United States., for example, despite Government subsidies for renewable energy projects in place for decades, new energy firms in solar power, biofuel, and wind power sectors have either failed to grow into major competitors, or have gone bankrupt following competition with other firms or energy technologies. Regulatory support and subsidy for renewable power (that contribute to consumption of new energy technologies) have so far not provided the United States with many leading firms or big changes to the existing energy mix, dominated as it has been for over a century by fossil fuel technologies.
} 
To date, ARPA-e has distributed approximately $\$ 760$ million in project funds, with over $50 \%$ going to Business and $37 \%$ to Universities, MIT and Arizona State University in particular. ${ }^{33}$ The future of energy innovation, therefore, is showing early indication of replicating similar organizational relations between Government, Business, and Universities presently observed across a range of other industries. In other words, ARPA-e shows many of the patterns in the data that we have described earlier, including heavy reliance by a Government agency on Business and Universities in generating the knowledge and products from which future energy innovations will diffuse through the economy. It is important to note that these activities will parallel ongoing support for energy $\mathrm{R} \& \mathrm{D}$ at the DoE and DoD, with coordinating mechanisms emerging from policy, economic conditions, and national security concerns. ${ }^{54}$

A final example of how Government distributes support for R\&D through networks of organizations is the National Nanotechnology Initiative (NNI). Created in 2000 and first funded in 2001, the NNI got additional organization and guidance support under the $21^{\text {st }}$ Century Nanotechnology Research and Development Act of 2003. Like clean technology, the development of nanotechnology creates possibilities across economic sectors (defying a simplistic industrial definition) and has numerous implications for improving social welfare (such as by contributing to revolutionary medical procedures and technologies). The NNI is not a single government agency but an organized R\&D effort engaged in a variety of activities and initiatives.

The NNI will contribute to Basic Research in nanotechnologies, standardization of measures needed by University researchers and Business, the manufacture of nanoscale technologies, as well as integration of nanotechnologies in electronics and clean-technology products. Nanotechnology is already incorporated into a number of consumer technologies (including beauty care, clothing, and automobiles), and applied as, for example, a cancer-fighting solution or to boost performance of electric storage technologies and semiconductors. In non-linear fashion, funding has supported a number of successful commercial products, with support for Basic Research being conducted at the same time that applications of technology are already underway. 55

So far, approximately $\$ 18$ billion in research support was provided to the NNI between 2001 and 2012, with $96 \%$ of Research budgets channeled through six original lead agencies including the DHHS, NSF, DoE, DoD, National Institute for Standards and Technology (NIST), NASA and EPA (there are 11 participating agencies currently). ${ }^{56}$ In addition to these government funds are Business funds of $\$ 3.5$ billion in the United States (or approximately $36 \%$ of the estimated global total in 2010), which include venture-capital funds (which globally were approximately $\$ 646$ million 2010).${ }^{57}$ At close to $\$ 2$ billion annually, the NNI is coordinated effort to utilize Government support to exploit the potentials of nanotechnology, but one which clearly relies on Universities and Business interaction to generating innovations.

It is important to note that NSF statistics do not take into account other sources of support for R\&D provided by the Government, such as the $R \& D$ tax credit which has been available to Business for

\footnotetext{
53 Author's ARPA-e database, as of February 2014.

${ }^{54}$ For an example of the complexity of support for energy innovation, see a comparative analysis by Laura Anadón, "Missions-Oriented RD\&D Institutions in Energy between 2000 and 2010: A Comparative Analysis of China, the United Kingdom, and the United States," Research Policy, 41, 10, 2012: 1742-1756.

55 "...much fundamental research remains ahead, including efforts to advance understanding of nanoscale phenomena." John Sargent Jr., "The National Nanotechnology Initiative: Overview, Reauthorization, and Appropriations Issues," Congressional Research Service, December 17, 2013: 4, at http://fas.org/sgp/crs/misc/RL34401.pdf.

56 John Sargent Jr., "Nanotechnology: A Policy Primer," Congressional Research Service, December 16, 2013, p. 6, at http://fas.org/sgp/crs/misc/RL34511.pdf

57 Ibid, p. 9.
} 
Who Invests in the High-Tech Knowledge Base?

decades and which provides a $\$ 5-\$ 10$ billion annual subsidy for Business R\&D each year. ${ }^{58}$ Another example are subsidies to Business for biotech drug development created under the Orphan Drug Act of 1983.59

Government programs also contribute to the start-up culture that characterizes the current U.S. high-tech economy. The Government does this, for example, by providing finance to young business enterprises that attract private and public equity. In particular, the Small Business Innovation Research Program (SBIR), launched with the Small Business Innovation Development Act of 1982, has provided about $\$ 40$ billion (in 2009 dollars) in R\&D grants to small companies. Funding is provided through twelve Government agencies with extramural R\&D budgets of greater than $\$ 100$ million, which must allocate $2.8 \%$ of their R\&D budgets to the SBIR program. 60 Though a number of agencies therefore participate, about $\$ 17$ billion (or $50 \%$ ) of SBIR funds have come from the Department of Defense (DoD).

Related to the SBIR program is the Small Business Technology Transfer Program (STTR), which provides $R \& D$ funding for small businesses working in collaboration with a research institution. ${ }^{61}$ The STTR program is presently funded by five government agencies with R\&D budgets of $\$ 1$ billion or more, which must channel $0.3 \%$ of their funding into it. Between 1995 and 2013, $\$ 3$ billion (in 2009 dollars) has been provided. Approximately $\$ 1.4$ billion (or $50 \%$ of funds) were provided through the DoD, as compared to $\$ 900$ million (or 28\%) through the DHHS (and therefore NIH).

The Advanced Technology Program (ATP) funded by the NIST of the U.S. Department of Commerce, made 824 cost-sharing awards to businesses between 1991 and 2007, before the program was replaced by NIST's Technology Innovation Program (TIP), which from 2008 through 2010 funded "\$280 million in high-risk, cutting edge research addressing the critical national need areas of civil infrastructure and manufacturing." 62

Government funding as we have reviewed it is not only organized around many social needs, but it is responsive to changing national priorities and perceived opportunities - funding research that Business may currently not value. The R\&D statistics alone make it appear as though for many decades now the Government's role has been to act mainly as a funder of R\&D; one which simply channels funds through agencies into yet other organizations that then conduct the research until innovations are transformed into commercial products. But as we have shown, there are examples of Government pursuing innovation through sponsorship of open networks that attract educated and experienced talent from the economy at large who, given their interests, are entrusted to efficiently distribute public funds into state of the art technology that is thought to serve the national interest. The statistics do not convey these sorts of strategic decisions well, or the extent to which "networking funds" promote organizational interaction culminating in technological and economic development. In relying on other organizations, Government supports the development of the knowledge base in part by connecting the resources of Households to the capabilities of Business and Universities around the country.

\footnotetext{
58 One recent report estimated the cost at between $\$ 5$ and $\$ 10$ billion annually. See Laura Tyson and Greg Linden, "The Corporate R\&D Tax Credit and U.S. Innovation and Competitiveness: Gauging the Economic and Fiscal Effectiveness of the Credit" Center for American Progress, January 2012.

59 William Lazonick and Öner Tulum, "US Biopharmaceutical Finance and the Sustainability of the Biotech Business Model," Research Policy, 40, 9, 2011: 1170-1187.

${ }^{60}$ Small Business Innovation Research Program, “The SBIR Program”, at http://www.sbir.gov/about/about-sbir

61 Small Business Innovation Research Program, "The STTR Program", accessed Aug 25, 2014 at http://www.sbir.gov/about/about-sttr

62 Technology Innovation Program, "Funding Innovation for Critical National Needs," National Institute of Standards and Technology, June 2011 at http://www.nist.gov/tip/factsheets/upload/tip_at_a_glance_2011.pdf
} 


\section{f) Business R\&D}

Our prior discussion described many aspects of the finance and performance of R\&D by Business. The list below is the NSF's summary of how key aspects of Business R\&D have changed since the NSF and the Census Bureau began collecting R\&D data:

1950s:

- Government is the largest source of R\&D funding

- Business is the largest basic research performer

- R\&D is dominated by manufacturing companies

- The largest companies dominate R\&D

- Focus on competitiveness within domestic markets

- Focus on in-firm science and technology resources and central research labs 2000s:

- Business the largest source of R\&D funding

- Academia the largest basic research performer

- R\&D Increasingly performed in service industries

- Increasing R\&D activity occurs within small companies

- Focus on global competitiveness

- Increased leveraging of science and technology resources outside the firm

Source: NSF.gov, (Nov 2008), "NSF Announces New U.S. Business R\&D and Innovation Survey," http://www.nsf.gov/statistics/infbrief/nsf09304/

It is of utmost importance to note that the stability of the share of $R \& D$ that Business performed over the entire six decades of NSF data masks fundamental changes in the ways in which Business performs R\&D. In the earlier decades, "Old Economy" companies did most of their R\&D in dedicated corporate research labs, which received large amounts of Government funds, mainly for military purposes, to do Basic Research and Applied Research. In the later decades, the corporate research labs disappeared, while large portions of R\&D spending shifted to "New Economy" startups that devoted most of their R\&D spending to product Development.63

Some of these startups have grown to be very large, but the statistics do not make it clear that they have sought to devote, as a result, more resources to Basic Research or Applied Research; there are no data available that distinguish between Basic Research or Applied Research by industrial sector or at the firm level. These startups, predominantly in ICT, biotechnology (particularly biopharmaceutical drugs), and clean technology (for example, solar power, wind power, and electric vehicles), have been able since the late 1970s to raise substantial amounts of venture capital in their private equity stages followed by public equity through share issues if and when they have done initial public offerings (IPOs). ${ }^{64}$ Where IPOs are not possible, many startups seek merger-and-acquisition (M\&A) deals, which generate financial returns for their investors and grant the startup access to the internal funds of the acquirers. ${ }^{65}$

${ }^{63}$ For the distinction between the Old Economy Business Model and the New Economy Business Model, see William Lazonick, Sustainable Prosperity in the New Economy? Upjohn Institute, 2009.

${ }^{64}$ As a result, for example, startups contribute to both booms and busts in R\&D spending. See James R. Brown, Steven Fazzari, and Bruce Peterson, "Financing Innovation and Growth: Cash Flow, External Equity, and the 1990s R\&D Boom," Journal of Finance, 64, 1, 2009: 151-185

65 National Science Board, Science and Engineering Indicators 2004, Chapter 6, available at http://www.nsf.gov/statistics/seind04/c6/c6s5.htm 
The expectations of venture capitalists and other startup financiers include rapid growth, usually sa a result of penetration into product markets often either unorganized or occupied by competing firms with superior resources and dominant legacy technologies under mass production. As discussed in the prior section, significant funding is provided by the Government in support of this startup 'culture' - typically directed at firms during their early "high-risk" stages (such as during technology proving). But all startup finance implicitly provides new Business enterprises an opportunity to overcome technological and commercial challenges.

As we noted, the growth in R\&D funding is primarily growth in Development funding and has occurred on the tail of significant past investments in the knowledge base made by Government, in response, for example, to national security crises. Aside from paying (or not paying) taxes which are then applied toward Government R\&D programs, Business typically devotes a portion of R\&D budgets to Universities and Nonprofits, from which it can potentially draw tremendous benefit. Benefits may especially accrue when Business investment is leveraged by Government investment in these organizations.

Figure 19 shows the proportions of funding Business directs into Universities and Nonprofits. Despite the fact that nearly all the funding Business devotes to R\&D is performed by itself, the funds it puts into other organizations are still quite large. Total Business funding for Universities and Nonprofits approximately doubled in real terms from 1953 ( $\$ 2$ billion) to 2011 ( $\$ 4$ billion). In contrast, Business spent $\$ 262$ billion doing in-house research in 2011, of which $\$ 227$ billion (or 88\%), was Development.

Fig 19. Business-Funded R\&D by Performer, Percent of Total, 1953-2011

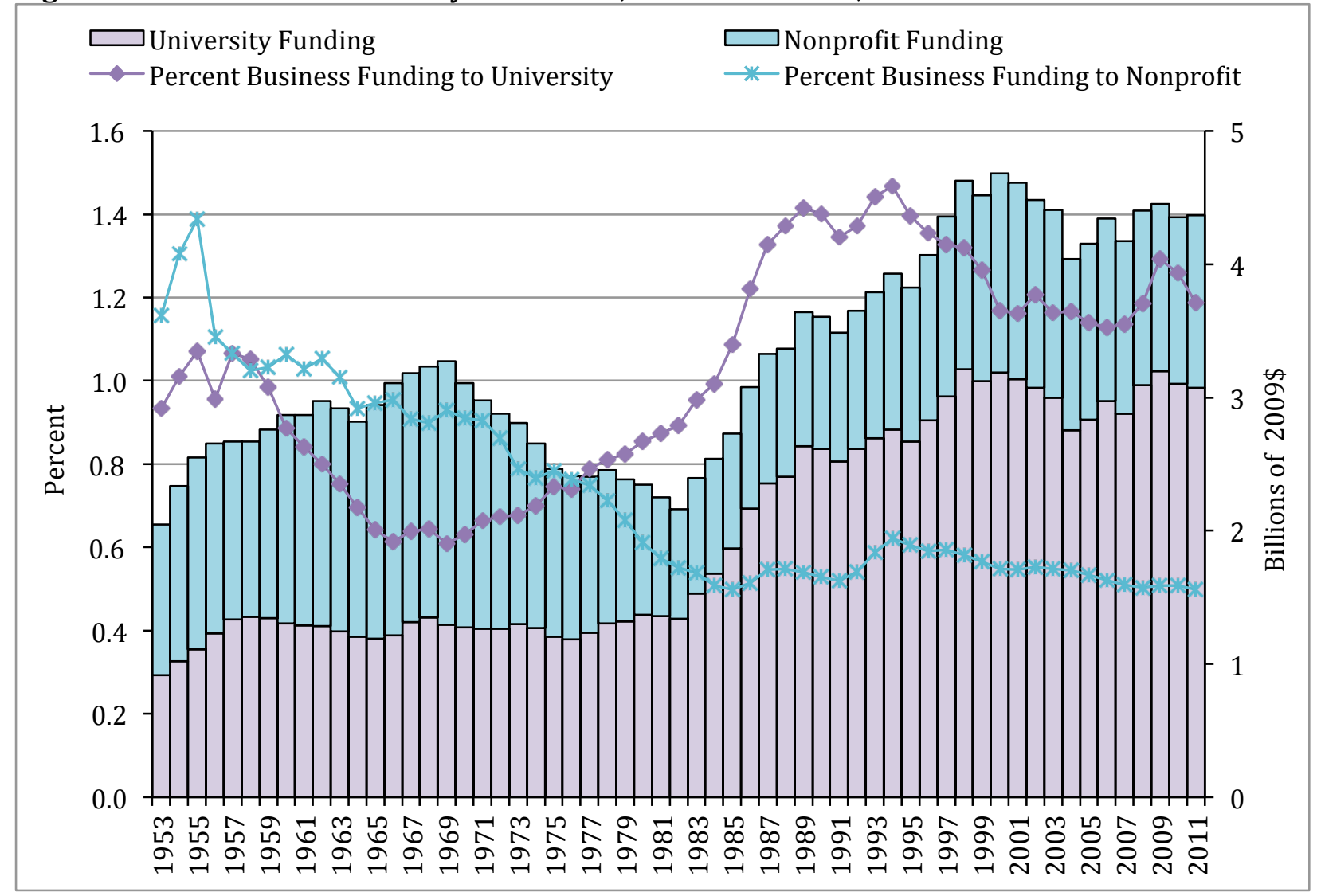

Source: NSF, table 4-6, "U.S. R\&D expenditures, by source of funds and performing sector: 1953-2011." 
The increased levels of funding for Universities are in part the result of Government policy, particularly following the Bayh-Dole Act and Stevenson-Wydler Act of 1980. The acts incentivized and mandated Government agencies to engage in technology transfer with other organizations. Prior to the Stevenson-Wydler Act, only the NASA had been mandated to engage in technology transfer activities. ${ }^{66}$ Later amendments to the act (such as the Technology Transfer Act of 1986) allowed for cooperative R\&D agreements (called CRADAS), and provided Government employees with limited capability to enter into technology commercialization. To encourage cooperative research, for example, cash incentives were made available to Government researchers.

The Bayh-Dole Act was partly a response to low utilization of Government-held patents, found to be just $5 \%$ in $1980 .{ }^{67}$ Bayh-Dole further opened opportunity for technology transfer by allowing nonGovernment organizations to own patents generated by Government research funds, and those patents (typically non-exclusive) could be used to generate licensing or product revenues. Universities, Nonprofits, and Business were all granted this privilege, while Government retained certain patent rights and pursued agreements with grantees over time frames for utilizing patents for production of a commercial product. Given that Universities in particular focus on teaching and research, Bayh-Dole essentially guaranteed that University research funded by the Government would seek outside partnerships with a Business and make an effort to transform any Government funded research that generates a patent into a commercial result. Where a partnership is not established, Universities pursue commercial spin-offs in large numbers. ${ }^{6}$

Starting in 1994, however, Business funding for University R\&D began falling in real terms, hovering around $1.2 \%$. It is in part a reflection of the difficulty of managing intellectual property rights, although that issue has existed at for as long as Business has provided funds for University research programs. Business enterprises that co-develop technologies with Universities tap into external professional talent pools and potentially unexpected sources of knowledge. But they do so with the expectation that it will contribute to their competitiveness or bottom line. Universities may be interested both in accessing auxiliary funding and unique research opportunities, but, as we shall discuss further in Section 4, walk a fine line between acting as scholars versus contracted employees of Business funders.

Yet of critical concern is how Business, through their now mainly Development expenditures, generate innovations that successfully compete for (national or global) markets. U.S. Business has had to "catch-up" with Business in foreign countries on several occasions, such as with the German chemical industry in the late $19^{\text {th }}$ and early $20^{\text {th }}$ centuries. Business also had to respond to the significant challenges of the Soviet Union during the Cold War (culminating in the Government-led, Business-executed space and arms race). The East Asian Tigers each emerged from the late 1980s to challenge what had been perceived to be U.S. superiority in a number of mass-production

\footnotetext{
66 "The primary law affording access to the federal laboratory system is P.L. 96-480, the Stevenson Wydler Technology Innovation Act of 1980, as amended by the Federal Technology Transfer Act of 1986 (P.L. 99-502), the Omnibus Trade and Competitiveness Act (P.L. 101-418), the 1990 Department of Defense (DOD) Authorization Act (P.L. 101-189), the National Defense Authorization Act for FY1991 (P.L. 101-510), the Technology Transfer Improvements and Advancement Act (P.L. 104-113), and the Technology Transfer Commercialization Act (P.L. 106-404)." Wendy Schacht, "Technology Transfer: Use of Federally Funded Research and Development," Congressional Research Service, December 3, 2009, pp. 3-4 at http://fas.org/sgp/crs/misc/RL33527.pdf

67 Wendy Schacht, "The Bayh-Dole Act: Selected Issues in Patent Policy and the Commercialization of Technology," Congressional Research Service, December 3, 2012, p. 2, at http://fas.org/sgp/crs/misc/RL32076.pdf

68 Other changes to patent law have had implications for interaction of Government, Business, and Universities. For example, Diamond v. Chakrabarty set a precedent in 1980 that allowed for the patenting of individual genes important to drug and other companies that produced genetically-modified food.
} 
industries, especially related to ICT. Today, China is positioned to become the world's largest economy, and a few indigenous Chinese high-tech firms have emerged that challenge the competitive position of the United States in a number of sectors. Economic competitiveness cannot be taken for granted, in other words, nor can Business in high-tech sectors afford not to engage in technology development. But a question is, can Business that relies increasingly on the organizational capabilities of the University system, and limited resources of the Government continue to respond to new competitive threats as they emerge?

To determine whether Business is succeeding or failing to make best use of the knowledge base which they in many ways finance to an increasingly smaller extent (given the decline in Business Research Labs and the proportionally small amount of funds being driven into Basic Research and Applied Research, as we noted earlier) - it is useful to identify the leading Business sectors. But analysis of R\&D figures alone is not enough as all Business enterprises competing in high-tech sectors face technological, market, and competitive uncertainties, all of which create organizational challenges and require strategic responses. Industries can differ dramatically in terms of technologies, markets, and competitors, and a history of success in one sector is usually not replicable in another sector. Similarly, even in the same industrial sector in the same industrial district, companies differ in terms of their strategy, organization, and technology. The innovation process is inherently unique in certain important dimensions, and the reasons for success or failure can only be fully understood through the empirical study of the business enterprise and industrial sector involved.

In the United States, the conduct of Business R\&D varies by firm size, with mainly very large or very small firms performing the majority of R\&D. The largest share of R\&D performance occurs within very large companies. Some $800-900$ firms with 25,000 or more employees conducted $36 \%$ of all Business R\&D in 2010, while firms with fewer than 500 employees conducted approximately 19\% of all R\&D. The R\&D strategies and resource allocations of these very large firms have an outsized impact on the course of innovation in the United States.

Business R\&D in the United States is also heavily regionally concentrated, with just ten states and metropolitan areas such as San Francisco and New York acting as the primary sites of a majority of Business funded and performed R\&D. ${ }^{69}$ In addition much of the R\&D done by Business occurs within a limited number of industries conducted by a limited number of firms, particularly those, for example, in the automotive, semiconductor or pharmaceuticals industries. North American Industry Classification System (NAICS) data is shown in Table 3. Among those industries with high levels of $R \& D$, the presence of Government support for $R \& D$ is found most prominently in the Manufacturing (NAICS 33) sector, within which aerospace (NAICS 3364) and the transportation equipment (NAICS 336) sectors are found.

Also notable is the distribution of funding by firm size, with the majority of Government funds going to large firms of 10,000 or more employees, which receive over $50 \%$ of $R \& D$ funds as a class. It is a reminder that efforts to foster innovation are made across a relatively small number of industries and firms.

\footnotetext{
${ }^{69}$ Brandon Shackelford, for NSF.gov, 12-326, Sept 2012, "Businesses Concentrate Their R\&D in a Small Number of Geographic Areas in the United States," http://www.nsf.gov/statistics/infbrief/nsf12326/
} 
Who Invests in the High-Tech Knowledge Base?

Table 3. Business R\&D by Major Funding Source and by Industry and Company Size, 2011

\begin{tabular}{|c|c|c|c|c|}
\hline Sector & $\begin{array}{l}\text { \% Of Total } \\
\text { Business R\&D } \\
\text { Funding } 2011 \\
\end{array}$ & $\begin{array}{l}\text { \% Funded by } \\
\text { the Company }\end{array}$ & $\begin{array}{l}\text { \% Funded by } \\
\text { Government }\end{array}$ & $\begin{array}{l}\% \text { Funded } \\
\text { by Others }\end{array}$ \\
\hline \multicolumn{5}{|l|}{ 2-Digit NAICS } \\
\hline Manufacturing industries, 31-33 & 68 & 81 & 11 & 8 \\
\hline $\begin{array}{l}\text { Nonmanufacturing industries, } 21-23,42- \\
81\end{array}$ & 32 & 81 & 7 & 12 \\
\hline Information, 51 & 14 & $\begin{array}{l}98 \text { ( } 2 \text { by } \\
\text { others)* }\end{array}$ & & \\
\hline $\begin{array}{l}\text { Professional, scientific, and technical } \\
\text { services, } 54\end{array}$ & 13 & 61 & 15 & 24 \\
\hline \multicolumn{5}{|l|}{ 3-Digit NAICS } \\
\hline Chemicals, 325 & 19 & 90 & 0 & 10 \\
\hline Computer and electronic products, 334 & 21 & 86 & 8 & 6 \\
\hline Transportation equipment, 336 & 14 & $\begin{array}{l}50 \text { (50 by } \\
\text { others)* }\end{array}$ & & \\
\hline Information Publishing, 511 & 10 & 98 & 2 & 0 \\
\hline \multicolumn{5}{|l|}{ 4-Digit NAICS } \\
\hline $\begin{array}{l}\text { Computer systems design and related } \\
\text { services, } 5415\end{array}$ & 5 & 88 & 5 & 7 \\
\hline $\begin{array}{l}\text { Scientific research and development } \\
\text { services }\end{array}$ & 5 & 40 & 21 & 39 \\
\hline Pharmaceuticals and medicines, 3254 & 16 & 89 & 0 & 10 \\
\hline $\begin{array}{l}\text { Aerospace products and parts, } 3364 \text { (2010 } \\
\text { Data)* }\end{array}$ & 11 & 34 & 63 & 3 \\
\hline \multirow[t]{2}{*}{ Software publishers, 5112 (2010 Data)* } & 10 & 98 & 0 & 2 \\
\hline & $\%$ by Total R\&D & $\begin{array}{l}\text { \% by Company } \\
\text { Funded }\end{array}$ & $\begin{array}{l}\text { \% by } \\
\text { Government } \\
\text { Funded }\end{array}$ & $\begin{array}{l}\% \text { by Other } \\
\text { Funded }\end{array}$ \\
\hline \multicolumn{5}{|l|}{ Company Size } \\
\hline $5-499$ & 19 & 82 & 7 & 18 \\
\hline $500-999$ & 3 & 87 & 4 & 13 \\
\hline $1,000-4,999$ & 17 & 85 & 3 & 15 \\
\hline $5,000-9,999$ & 8 & 75 & 2 & 25 \\
\hline $10,000-24,999$ & 17 & 87 & 7 & 13 \\
\hline 25,000 or More & 35 & 77 & 21 & 23 \\
\hline
\end{tabular}

Source: NSF, Appendix Table 4-15, "Domestic business R\&D by major funding source, by industry and company size: 2008-11"

*Data suppressed. Some 4-Digit codes reported in 2010 are not found in the 2011 release. Here we include 2010 data to show Transportation Equipment and Information Publishing sectors are likely still largely reflective of R\&D done by Aerospace firms and software publishers.

A second source of data, Standard and Poor's Compustat, supports some of these findings while making it possible to move beyond broad data aggregations and the problem of data-suppression typical of survey-based data. The NSF's data are more inclusive, because they include private as well as public firms with, most recently, a total population of two million and sample size of 45,000 firms. Yet despite the inclusion of private firms, the vast majority of companies surveyed to 
Who Invests in the High-Tech Knowledge Base?

generate the NSF database are public firms, and hence public firms make up a significant proportion of reported U.S. Business R\&D spending and performance. ${ }^{70}$

A relatively small number of large firms in the United States fund and perform a substantial amount of R\&D each year, and many have done so on an annual basis for decades. It is on these firms that we rely to deliver innovation on a large scale and on a regular basis. These are firms such as Western Digital, General Motors, Xerox, Texas Instruments, Qualcomm, Proctor \& Gamble, Microsoft, Merck \& Co, Johnson \& Johnson, Intel, Google, DuPont, Cisco, Apple, Amazon, and Amgen, to name a few. Many of these firms dominate their industries and command considerable influence not only over what kinds of R\&D projects are ultimately valued by the economy today (given the technologies they seek to develop), but also over the ways in which educated labor is trained, utilized and rewarded for carrying out their core R\&D activities. Many of these companies also employ well over 25,000 employees, not all of whom are based in the United States. ${ }^{71}$

Our preliminary research of the Compustat database shows that, when data are examined from 1985-2013, a picture of leading firms (and associated Industries) becomes more clear. When data are sorted by total R\&D expense and adjusted for inflation over the 1985-2013 period, the top 10 spenders made up 30\% of the recorded expenditures of the top 500 firms. When the aggregate expenditures of the top 100 firms are included, we can account for $77 \%$ of all recorded R\&D expenditures of the top 500 firms. Table 4 summarizes the top 10 firms by R\&D expenditure.

Table 4. Aggregate R\&D Expenditures of the Top 10 Publicly Listed Companies, 1985-2013 (Millions of 2009\$)

\begin{tabular}{|c|c|c|c|c|c|}
\hline Rank & & $\begin{array}{l}\text { Industry } \\
\text { NAICS } \\
\text { Code } \\
\end{array}$ & Industry Description & $\begin{array}{c}\text { Total R\&D } \\
\text { Expenditures } \\
\text { (\$millions) }\end{array}$ & $\begin{array}{c}2013 \text { U.S. } \\
\text { Employ- } \\
\text { ment }\end{array}$ \\
\hline 1 & GENERAL MOTORS & 336110 & Automobile Manufacturing & 232,327 & 213,000 \\
\hline 2 & FORD MOTOR & 336110 & Automobile Manufacturing & 195,320 & 171,000 \\
\hline 3 & IBM & 541519 & Other Computer Services & 176,314 & 434,246 \\
\hline 4 & PFIZER & 325412 & $\begin{array}{l}\text { Pharmaceutical } \\
\text { Preparation Manufacturing }\end{array}$ & 133,263 & 91,500 \\
\hline 5 & JOHNSON \& JOHNSON & 325412 & $\begin{array}{l}\text { Pharmaceutical } \\
\text { Preparation Manufacturing }\end{array}$ & 121,116 & 127,600 \\
\hline 6 & MICROSOFT & 511210 & Software Publishers & 119,048 & 94,000 \\
\hline 7 & INTEL & 334413 & $\begin{array}{l}\text { Semiconductor and Related } \\
\text { Device Manufacturing }\end{array}$ & 110,847 & 105,000 \\
\hline 8 & MERCK \& CO & 325412 & $\begin{array}{l}\text { Pharmaceutical } \\
\text { Preparation Manufacturing }\end{array}$ & 100,484 & 83,000 \\
\hline 9 & HEWLETT-PACKARD & 334100 & $\begin{array}{l}\text { Electronic Computer } \\
\text { Manufacturing }\end{array}$ & 86,856 & 331,800 \\
\hline \multirow[t]{3}{*}{10} & & \multirow[t]{3}{*}{334220} & $\begin{array}{l}\text { Wireless Communication } \\
\text { Equipment Manufacturing }\end{array}$ & 81,324 & 21,000 \\
\hline & \multirow{2}{*}{ MOTOROLA } & & $\begin{array}{l}\text { Total Expenditures of Top } \\
500 \text { firms }\end{array}$ & $\begin{array}{r}\text { Top } 10 \text { as } \% \\
\text { of top } 500 \\
\end{array}$ & $\begin{array}{r}\text { Total } 2013 \\
\text { Employment }\end{array}$ \\
\hline & & & $4,489,264$ & 30.2 & $1,689,496$ \\
\hline
\end{tabular}

Source: S\&P Compustat Database.

\footnotetext{
70 Matt Hopkins e-mail communication with Raymond Wolfe of the NSF on the BRDIS survey, Aug 8, 2014. Unfortunately, neither the NSF nor U.S. Census currently track U.S. R\&D expenditures by firm ownership.

${ }^{71}$ For example, in 2013, Ford Motor Company had 171,000 employees, of which 84,000 (49\%) were based in the U.S.
} 
Who Invests in the High-Tech Knowledge Base?

The composition of the top 10 list changes depending on selection year. But since the 1960s (when leading firms made up 58\% of all expenditures) the largest R\&D spenders have tended to represent a third or more of all R\&D spending in a given year. In 2000, chemicals manufacturers such as Kodak, DuPont, and Dow Chemical were still at the top of the charts. In 1990, Aerospace companies Boeing and United Technologies were leaders. In 1980 AT\&T, which still owned and controlled Bell Labs, was a leading spender in the telecommunications industry (NAICS 517).

Currently the top 460 firms in the Compustat database spend $\$ 1$ billion or more on R\&D annually. As we showed earlier, investment in R\&D has grown in real terms over the last several decades. Yet, beginning in the 2000s, Business funding for R\&D has been flat or falling in real terms. Is it cause for concern? Given differences in the expenses required to develop new products across Business sectors (for example, developing a commercial airliner versus synthesizing a drug), flat or falling spending levels may reflect a sectoral change, not a systemic crisis in Business R\&D. Yet the apparent need for investment in the high-tech knowledge base is greater than ever (not just Development, but Basic Research), as challengers to dominant U.S. firms now come from many countries. Why then, is U.S. Business contracting commitments to R\&D? Where the commitments are not necessarily contracting, are the firms out-innovating their rivals? The search for an explanation can, and should begin with close examination of the leading industries and companies that interact with Universities and Government in the ongoing attempt to both build the U.S. knowledge base and utilize it for the purpose of superior economic performance. These are also the companies whose employment practices will have a preponderant influence on the incentives and abilities of U.S. Households to invest in the next generation of people who pursue high-tech careers.

\section{g) University $R \& D$}

Universities surpassed Government as the second-largest site for R\&D performance in 1998. According to the NSF data, the last 20 years have seen a shift away from the physical sciences and a transition toward life-science dominated R\&D, suggesting a rather narrowly focused $R \& D$ agenda for Universities in the United States.

We have established that Universities perform significant amounts of R\&D (particularly Basic and Applied Research), but they do not fund it. NSF data tracking R\&D expenditures by Universities can help to highlight the importance of Household support for R\&D through tuition payments as well. In 2011, leading Universities collectively spent a record $\$ 65$ billion on R\&D, the majority of funding provided by Government and Households. As shown in Figure 20 below, University expenditures of approximately $\$ 2$ billion grew to over $\$ 60$ billion in real terms between 1953 and 2012, an average annual growth rate of $14 \%$. Yet commitments from the federal and state governments have fallen over time, despite providing over $70 \%$ of funds, on average, for the performance of University R\&D.

Despite overall growth in performance of R\&D, most sources of funding to Universities have been fairly stagnant or in decline. Counter to that trend has been growth in funding provided by University revenues ('Institution'), derived from tuitions and endowments among other sources, and to a limited extent contributions from Business, which we showed earlier directs a small portion of its R\&D budgets into University research. However Business R\&D funding for University research which grew, on average, 12\% annually between 1953 and 1957, is currently declining in real terms, growing just $1.5 \%$ on average between 2000 and 2012. Picking up the slack have been the internal revenues of Universities, which represented (at a lowest point) about 8\% of R\&D funds in 1964 before growing to about $20 \%$ of funds by 2012. In 2009 dollars, that was $\$ 560$ million for R\&D in 1964, growing to $\$ 12$ billion in 2012 . 
Figure 20. University Performance of R\&D, by Source of Funds, 1953-2012

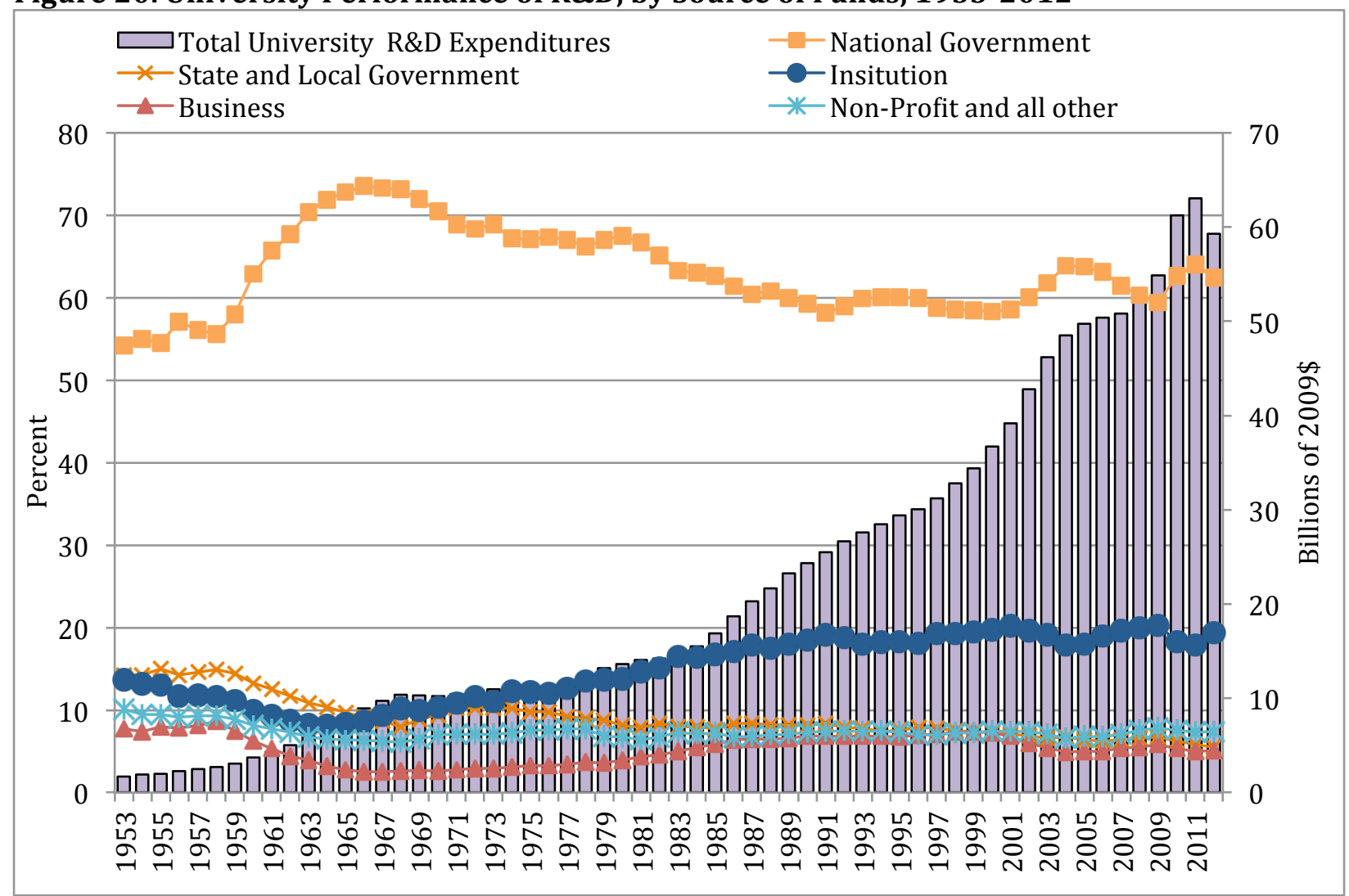

Source: NSF, Table 1, "Higher education R\&D expenditures, by source of funds and R\&D field: FYs 1953-2012."

As we have seen in Government and Business $R \& D$, the majority of University $R \& D$ occurs at a relatively small number of institutions. Shown in Table 5 below, just 100 Universities make up over three-quarters of the performance of $R \& D$, and the top 500 Universities account for almost all the R\&D in the United States. Much of those budgets are devoted to a relatively narrow group of academic disciplines, and primarily life sciences, whereas in the post-World War II decades large amounts of resources were poured into physics departments. Between 2003 and 2012, life science research has represented an almost steady 58 percent of all University R\&D.

From a regional perspective, $43 \%$ of $R \& D$ at Universities in 2012 occurred in six states, in particular at Universities in California (13\% of that total), New York (8\%), Texas (7\%), Maryland, Pennsylvania, and Massachusetts (5\% each). Within the top states are major Universities such as the several University of California campuses (Berkeley, Los Angeles, San Diego and San Francisco), Stanford (California), Texas A\&M and University of Texas at Austin, Columbia (New York), Johns Hopkins (Maryland), and MIT and Harvard (Massachusetts).

Johns Hopkins was established as the first research university in the United States in 1876, and currently is the leading University in terms of R\&D expenditure, which is about $\$ 2$ billion annually, much of which is linked to DoD and DHHS R\&D support. ${ }^{72}$ Much of the funding it receives in support of this R\&D is for life sciences research, which is expected given high levels of Basic Research

\footnotetext{
72 Richard C. Atkinson and William A. Blanpied, "Research Universities: Core of the US Science and Technology System," Technology in Society, 30, 1, 2008: 30-48.
} 
Who Invests in the High-Tech Knowledge Base?

granted by the NIH. Presently only eight Universities in the United States expend $\$ 1$ billion or more on $R \& D$, all of them getting half or more of their funding from the Government.

Table 5. Total R\&D Budgets by University (\$Billions), 2003-2012

\begin{tabular}{|lllllllllll|}
\hline Total R\&D & & & & & & & & & \\
Spending (Billions) & $\mathbf{2 0 1 2}$ & $\mathbf{2 0 1 1}$ & $\mathbf{2 0 1 0}$ & $\mathbf{2 0 0 9}$ & $\mathbf{2 0 0 8}$ & $\mathbf{2 0 0 7}$ & $\mathbf{2 0 0 6}$ & $\mathbf{2 0 0 5}$ & $\mathbf{2 0 0 4}$ & $\mathbf{2 0 0 3}$ \\
\hline Top 10 & 11.6 & 11.5 & 10.7 & 9.4 & 8.9 & 8.5 & 8.2 & 7.9 & 7.4 & 7.0 \\
Top 50 & 36.2 & 35.7 & 33.5 & 28.9 & 27.4 & 26.1 & 25.1 & 24.0 & 22.5 & 21.1 \\
Top 100 & 51.1 & 50.4 & 47.5 & 41.0 & 38.7 & 37.0 & 35.7 & 34.1 & 32.1 & 29.8 \\
Top 200 & 61.7 & 61.0 & 57.4 & 48.9 & 46.4 & 44.3 & 42.6 & 40.8 & 38.3 & 35.5 \\
Top 500 & 65.5 & 64.9 & 61.0 & 51.6 & 48.8 & 46.6 & 44.8 & 42.9 & 40.3 & 37.2 \\
\hline Total Funding & $\mathbf{6 5 . 8}$ & $\mathbf{6 5 . 3}$ & $\mathbf{6 1 . 3}$ & $\mathbf{5 7 . 3}$ & $\mathbf{5 4 . 1}$ & $\mathbf{5 1 . 6}$ & $\mathbf{4 9 . 6}$ & $\mathbf{4 7 . 5}$ & $\mathbf{4 4 . 8}$ & $\mathbf{4 1 . 5}$ \\
\hline Total R\&D Spending (As percent of total) & & & & & & & \\
\hline Top 10 & 17.7 & 17.6 & 17.5 & 16.4 & 16.4 & 16.5 & 16.5 & 16.6 & 16.5 & 16.9 \\
Top 50 & 55.0 & 54.7 & 54.7 & 50.5 & 50.7 & 50.6 & 50.6 & 50.5 & 50.2 & 51.0 \\
Top 100 & 77.7 & 77.2 & 77.5 & 71.5 & 71.6 & 71.8 & 71.9 & 71.8 & 71.5 & 71.9 \\
Top 200 & 93.7 & 93.4 & 93.7 & 85.4 & 85.7 & 85.9 & 85.8 & 85.8 & 85.4 & 85.5 \\
Top 500 & 99.7 & 99.4 & 99.6 & 90.1 & 90.2 & 90.3 & 90.1 & 90.3 & 89.9 & 89.8 \\
\hline Total Number of & & & & & & & & & & \\
Degree-granting & 4,706 & 4,599 & 4,495 & 4,409 & 4,352 & 4,314 & 4,276 & 4,216 & 4,236 & 4,168 \\
Institutions & &
\end{tabular}

Sources: National Center for Education Statistics, Table 306, "Degree-granting institutions, by control and level of institution: Selected years, 1949-50 through 2011-12" http://nces.ed.gov/programs/digest/d12/tables/dt12_306.asp; "NSF National Center for Science and Engineering Statistics (NCSES): Rankings by total R\&D Expenditures" http://webcaspar.nsf.gov/profiles/site;jsessionid=CE6889F91ED1AE83BDF849EE4DB265E2? method=rankingBySource \&ds=herd

A final note is the difference in the distribution of $R \& D$ funding between Public and Private Universities. In 2009, Private Universities received greater Government support for R\&D than Public Universities (70\% versus 55\%), while Public Universities relied more heavily on internal funds for meeting their R\&D costs (about 25\% versus 10\%); as well as state and local funds (10\% versus less than $5 \%$ ).

$\mathrm{R} \& \mathrm{D}$ funding at Universities, whether public or private, are sourced in large part from the Government, with the exception that public schools rely more heavily on Household families and state and local Governments. Private Universities receive more federal Government funding for $\mathrm{R} \& \mathrm{D}$, but both public and private Universities attract nearly the same amount of funding support from Business. ${ }^{73}$

\footnotetext{
73 For more details see National Science Board, Science and Engineering Indicators 2012, Chap 5, "Academic Research and Development" at http://www.nsf.gov/statistics/seind12/c5/c5h.htm
} 


\section{Innovation as a Collective and Cumulative Social Process}

\section{a) An Innovation System in Crisis}

A recent report by the American Academy of Arts \& Sciences (AAAS), Restoring the Foundation: The Vital Role of Research in Preserving the American Dream, ${ }^{74}$ evokes a crisis in U.S. competiveness to argue that the nation's prosperity depends upon an accelerated and sustained commitment to the finance of basic research by the federal government, to be carried out primarily through universities. ${ }^{75}$ The AAAS Committee for New Models on U.S. Science and Technology Policy posits that there are critical and complementary roles for "government, university, business, industry, state government, and philanthropy" to play in carrying out the nation's R\&D.76 They view innovation as a non-linear process that "occurs in a web in which ideas, data, and people move freely, improving both the quality and speed of work."77 The Committee notes that "today's business culture does not reward long-term investment." 78 Yet the report provides no insights into why this culture exists, how it undermines investment in innovation, or what type of "long-term" investments business should be making. ${ }^{79}$

Restoring the Foundation recognizes that several stakeholders carry out broad investments in innovation in the United States, but makes no attempt to analyze how social institutions integrate household, government, and business strategies for investing in the high-tech knowledge base. The relationships that constitute the Investment Triad are not based on an amorphous "web". Rather they are embedded in social institutions that must be studied to understand the conditions that transform investments in the high-tech knowledge base into innovative goods and services. A focus on how government as funders and universities as performers of R\&D can contribute to innovative outcomes is an important part of the study of "the Foundation" that needs to be restored. But such a study is useless if it is not extended to the study of the social conditions under which businesses undertake investments that are inherently collective, cumulative, and uncertain - i.e., "long term" and the types of investments in the knowledge base that such long-term commitments of capital entail. The "financialization" of the U.S. industrial corporation is not an esoteric phenomenon. ${ }^{80}$ Nor

\footnotetext{
${ }^{74}$ Committee for New Models on U.S. Science \& Technology Policy, Restoring the Foundation: The Vital Role of Research in Preserving the American Dream, American Academy of Arts \& Sciences, 2014, at http://www.amacad.org/content/Research/researchproject.aspx?d=1276. The Committee (p. 12) states that "in economic terms, the American Dream has meant having a decent job: not an easy or lucrative job, but one that could provide a livable wage and afford the next generation of Americans the opportunity for a better life than their parents had lived."

75 The AAAS Committee specifically recommends an increase of basic research spending at a real annual rate of $4 \%$ at minimum. Additional recommendations include (but are not limited to) increased reporting on the state of Science \& Engineering in the United States; stakeholder meetings; reform of University-Business intellectual property rules; permanent tax credits for R\&D; increased spending by business on University R\&D; and increased numbers of H1-B visas.

76 Ibid., p. 109

77 Ibid., p. 41

78 Ibid., p. 59

${ }^{79}$ See a companion paper, by William Lazonick, Philip Moss, Harold Salzman, and Öner Tulum, (Oct 2014) "Skill Development in STEM Occupations: Collective and Cumulative Careers Confront Skill-Biased Technical Change," theAIRnet, in process. The authors explain how "collective and cumulative careers" are the source from which business draw innovative capabilities, increased productivity, and, over time, the profits from which an improved standard of living can be supported.

80 William Lazonick, "The Financialization of the U.S. Corporation: What Has Been Lost, and How It Can Be Regained," Seattle University Law Review, 36, 2013: 857-909.
} 
is "innovation" simply a term that can be invoked with a theory of the social conditions under which it takes place. Effective science and engineering policy requires a theory of innovative enterprise. ${ }^{81}$ Restoring the Foundation assumes that increased public spending on R\&D will result in an increase in innovative outcomes. Yet the analysis of NSF R\&D data that we have presented shows that, by any measure, the United States is spending more now on R\&D than it has in the past. Since the 1950s, moreover, the vast majority of R\&D has been performed by Business. Our review of the NSF $R \& D$ data shows that in the $21^{\text {st }}$ century the United States still spends an enormous amount on R\&D, with Business now expending far more than Government. Notwithstanding the disappearance of the Old Economy corporate research labs, much of Business R\&D spending is on Basic Research, not just on Development. The source of the innovation crisis may well be attributable to, as Lazonick, Moss, Salzman, and Tulum argue, 82 a lack of R\&D productivity, not a lack of R\&D spending. In this concluding section of this report, we argue that in the absence of major changes in America's financialized "business culture", more spending on R\&D will not solve the problem of a dearth of innovation or the need to promote a higher standard of living.

We know from the experience of various types of economic and social systems that more spending is not necessarily better spending. If it were the most profligate spenders would also be the most efficient and productive innovators. For example, the United States spends 17.5\% of GDP on health care while no other major nation spends more than $11.7 \%$ (France). ${ }^{83}$ Yet no one could claim that the United States has the best health care system in the world. Indeed in some dimensions such as the numbers of people who lack health insurance, overly bureaucratic insurance systems, and the extent to which top executives in health-related industries (as in the U.S. economy as a whole) extract outsized personal compensation for themselves, one could argue that the U.S. health care system is the worst of the advanced economies.

Despite all of the spending on R\&D, both by Business and Government, there is a mounting consensus among scholars who study how the U.S. economy innovates that the United States is falling short. Here are extended quotes from four recent studies of the U.S. high-tech economy that argue that the capacity of the United States to engage in innovation has declined:

- Eugene Fitzgerald, Andreas Wankerl, and Carl Schramm, Inside Real Innovation: How the Right Approach Can Move Ideas from R\&D to Market - And Get the Economy Moving Again (World Scientific Publishing 2011), pp. 2-3.

"If we want to restore the economy to real vitality, instead of just settling for periodic upticks in the vital signs, we need to deal with the fact that beneath the financial crisis, we have an innovation crisis.

Innovation - the process of putting ideas into useful form and bringing them to market - is the true engine of economic growth. This has been true since ancient times, although only fully recognized in modern times. These "ideas put into useful form" have enabled us to raise our productivity, whether it's by plowing fields more efficiently with an iron-bladed plow, by restoring our health with an antibiotic - or by flying like a bird except much faster, in a machine that also can transport a wagon train's worth of goods. Some of the most powerful innovations are those for which we find so many uses that the benefits keep multiplying: computers are now so valuable in every walk of life that it can be hard to remember they were first created, literally, for computing. Fundamental innovations

81 William Lazonick, “The Chandlerian Corporation and the Theory of Innovative Enterprise," Industrial and Corporate Change, 19, 2, 2010: 317-349;

82 Lazonick et al., "Skill Development in STEM Occupations".

83 World Bank, Data, Health Expenditure, Total (\% of GDP), at

http://data.worldbank.org/indicator/SH.XPD.TOTL.ZS/countries?display=default 
Who Invests in the High-Tech Knowledge Base?

of this kind have the power to create multiple companies and multiple industries. The resulting innovation paradigms can generate economic growth for decades.

And the most powerful growth-driver of all is what makes it all happen, the human process of innovating. Despite the fact that we humans are the ones doing it, the workings of this process are still not widely understood. Only in recent times have we begun to grasp the immense value of assuring that the process runs well, and finding ways to help it run better. The crisis, as we shall see, is the manifestation of changing conditions that have disrupted the support system for innovation, allowing the process to sputter and run down - even as we were busy reaping its benefits. All sectors, not only the financial sector, have been both culprits and victims in letting this occur."

- Gary P. Pisano and Willy C. Shih, Producing Prosperity: Why America Needs a Manufacturing Renaissance (Harvard Business Review Press, 2012), pp. 1-2.

"A combination of company strategies, management thinking, and government policy has led to the gradual erosion of the country's industrial commons: the R\&D and manufacturing infrastructure, know-how, process-development skills, and engineering capabilities embedded in firms, universities, and other organizations that provide the foundation for growth and innovation in a wide range of industries.

This erosion is the result of a grand economic experiment based on the hypothesis that an advanced economy can continue to prosper and grow even as manufacturing declines because services and other knowledge-based sectors will fill the gap and leave it better off. The stakes involved are enormous. This kind of de-industrialization process can play out over decades. If, in the end, the 'manufacturing does not matter' hypothesis proves wrong-and we think that's exactly what's going to happen - the United States (and other countries that have been running the same experiment) will have a big problem on its hands.

The purpose of this book is to persuade business and government leaders to abandon the grand experiment in de-industrialization before it's too late. We argue and present evidence that an industrial commons matters for an advanced economy, explore the underlying causes of its erosion in the United States, and offer ideas about what's needed to reverse that decline."

- Robert D. Atkinson and Stephen J. Ezell, Innovation Economics: The Race for Global Advantage (Yale University Press, 2012), pp. 2-3.

"[N]either the recession nor the slow recovery can be attributed simply to a random financial crisis caused by the burst housing bubble. Rather, we argue that a major contributing factor has been the United States falling behind in the race for global innovation advantage. Indeed, since the late 1990s especially, the United States has been losing out to other nations with respect to competitiveness and innovation, the result of too few resources going to wealth-creating investments like research and factories and too many resources going to a housing-market Ponzi scheme. America lost almost onethird of its manufacturing jobs from 2000 to 2011, while it ranked forty-third out of forty-four nations in the rate of progress in innovation-based competitiveness. Until U.S. policymakers grasp and act on this fundamental reality, we can expect recovery to be anemic and the United States to continue to lose ground relative to most other nations. Recovery will depend on two mutually reinforcing factors: a faith that America will once again lead in the global innovation economy and sufficient private and public investments in research, plant and equipment, skills, and infrastructure to realize that vision."

- Suzanne Berger with the MIT Taskforce on Production in the Innovation Economy, Making in America: From Innovation to Market (MIT Press, 2013), pp. 1-2. 
Who Invests in the High-Tech Knowledge Base?

"Over the past decade, as millions of jobs disappeared in a flood of Asian imports and a severe financial and economic crisis, pessimism about the future of production in the United States swept across the country. People started to question whether U.S. manufacturing could ever compete with Asian low-wage production. The trade deficit in advanced technology products deepened-equal to 17 percent of the total U.S. trade deficit by 2011-and it seemed that even high-tech sectors of industry were doing better overseas than here. As in past times of trouble, some blamed foreign governments for damaging U.S. manufacturing by subsidizing their own companies and protecting their national currencies. But even the critics of foreign governments knew there was something wrong at home.

Everyone agreed that the United States needed a higher rate of good job creation, but no one seemed to know where jobs could come from. Could manufacturing jobs come back? The brightest corporate superstars, like Apple, were locating production abroad and still reaping the lion's share of profits within the United States. Was this going to be the American model for the future? In emerging technology sectors, like batteries and solar and wind power, even when the start-ups were created in the United States out of U.S. innovations, commercialization of the technology was taking place abroad. What could Americans do to leverage their strengths in new science and technology to rebuild a dynamic economy? Would production capabilities at home be needed to capture the flow of benefits from invention and entrepreneurship? Which capabilities? And how could they be created and sustained?"

There are no serious studies of the current U.S. innovation system that contradict the argument that the U.S. system is feeble and faltering. Studies such as the ones quoted above give us various insights into how the U.S. innovation system is falling short of its potential in a global economy in which a number of nations, mainly in Asia, are far exceeding what the pundits thought their innovative potential would be. In our view, however, the new spate of studies of the U.S. innovation crisis does not take us very far in explaining why the U.S. economic system is underperforming its potential. In this final section of this report, we build on the historical perspective and statistical synopsis that we provided in Sections 2 and 3 to outline an approach to understanding the evolving operation and performance of the U.S. innovation system. Our purpose here is not to supply all the answers, but to help focus ongoing research on these issues on the key questions while pointing the way to the types of research that can explain not only how the "innovation crisis" is occurring but also why.

\section{b) Innovation as an Interactive Process}

As we have already explained, our approach to analyzing the operation and performance of the U.S. innovation system centers on the interaction of household families, government agencies, and business enterprises in investing in the high-tech knowledge base. The study of the comparativehistorical development of nations tells us that if a nation does not invest in the high-tech knowledge base it cannot attain a reasonably high standard of living. The critical question is how the three economic actors who constitute the investment triad interact in the development of the economy. More specifically, we can ask whether Households, Government, and Business pursue mutually reinforcing investment strategies, or whether they are at odds with one another.

First and foremost, national economic development depends on investment in an education system through which the population can become highly literate and then use that literacy to accumulate knowledge that is relevant, directly or indirectly, to the performance of a productive economy. Through the combined investments of households and governments, a significant proportion of high-school-educated population can complete at least a bachelor's degree and a more select group 
can obtain a professional master's degree or a specialized doctoral degree.

The critical question is then whether this highly educated population can find relevant employment that permits them not only to earn a living but also to continue to accumulate knowledge through work experience over the course of their careers. In national economies that are accumulating a high-tech knowledge base, it is business enterprises that provide households with the vast majority of these high-tech employment opportunities. To a much lesser extent government agencies as well as universities also provide households with high-tech career opportunities as these organizations perform their roles of providing business enterprises with public knowledge and high-tech personnel.

In a well-functioning innovation system, the investment strategies of business enterprises drive the interactions within investment triad. As an example of what happens when the investment triad lacks innovative business enterprises, think of the Soviet Union, the former "Super-Power" with its capability of putting the first satellite in orbit, but its utter incapability to this day of generating a single global competitor in any high-tech industry or even in automobile manufacturing. ${ }^{84}$ In 1991 when the Soviet Union collapsed under its own militarized weight, there was China, another Communist nation but with four times the U.S.S.R.'s population, emerging as the world's most dynamic economy, largely because of the willingness of the post-Mao Communist Party to encourage the formation of business enterprises in a wide variety of industries, including hightechnology, that are neither owned nor controlled by the State. Chinese government agencies at all levels have supported the growth of innovative business enterprise through massive investments in physical infrastructure and a public education system. But increasingly it has been innovative business enterprises that have been driving the rapid and sustained growth of the Chinese economy. ${ }^{85}$

In the 1980s, the influential book, MITI and the Japanese Miracle, by American political scientist Chalmers Johnson, 86 led many scholars of comparative political economy to tout the "developmental state" as the driving force of Japan's transformation from poverty to affluence. But it was the investment strategies and organizational structures of Japan's business corporations such as Toshiba, Hitachi, Toyota, Nissan, Matsushita, Sony, Canon, and many more that, by the 1970s and 1980s, provided that nation with a globally competitive innovation system. The Bank of Japan and associated "main-bank" lenders played important roles in financing the rapid growth of these companies on the basis of high debt-equity ratios. In terms of technology policy, however, it was the innovation system of the United States, far more than the Japan's Ministry of International Trade and Industry (MITI), that functioned as Japan's "developmental state", as through a process of "indigenous innovation," Japanese companies transferred U.S. technologies, absorbed them into

\footnotetext{
84 See Forbes 2014 list of the world's 2000 biggest companies, which includes just 28 Russian companies, all of which are either in natural resources, metals, power and telecommunication utilities, or finance: http://www.forbes.com/global2000/list/\#page:1_sort:0_direction:asc_search:_filter:All\%20industries_filter:Russia_filt er:All\%20states. In contrast, Japan has 237 companies on the list of which large numbers are high-tech or complexsystem industrial companies.

85 Qiwen Lu, China's Leap into the Information Age: Innovation and Organization in the Computer Industry, Oxford University Press, 2000; William Lazonick “Indigenous Innovation and Economic Development: Lessons from China's Leap into the Information Age," Industry \& Innovation, 11, 4, 2004: 273-298; William Lazonick and Yin Li, "China's Path to Indigenous Innovation," AIR Working Paper, revision in progress; Yu Zhou, William Lazonick, and Yifei Sun, eds., China as an Innovation Nation, Oxford University Press, forthcoming.

${ }^{86}$ Chalmers Johnson, MITI and the Japanese Miracle: The Growth of Industrial Policy, 1925-1975, Stanford University Press, 1982.
} 
their business organizations, and then improved upon them. ${ }^{87}$

Similar arguments can be made about the centrality of the business enterprise to the technological development of the economies of Europe in the post-World War II decades and East Asian nations such as South Korea and Taiwan since the 1970s. All of these development experiences, including that of the United States which we reviewed in Section 2 of this report, expose as irrelevant the neoclassical theory of the market economy - or what Lazonick has called "the myth of the market economy" 88 - for explaining economic growth. But the centrality of the business enterprise to the investment triad also contradicts the "linear model" of technological development, directed by government agencies, envisioned in Vannever Bush's Science - The Endless Frontier, which found expression in the 1950 founding of the National Science Foundation.89 Indeed, just after its founding, the NSF constructed the categorization of R\&D activities as Basic Research, Applied Research, and Development - yielding the time series that we used in Section 3 - with the linear model in mind. ${ }^{90}$

In fact, however, the innovation model that was successful in making the United States the world leader in science and technology from the late $19^{\text {th }}$ century was one in which Business and Government interacted to invest in the high-tech knowledge base. In a sector such as agriculture in which business enterprises - in this case family farms - were numerous and small, government agencies took the lead. In those in which a small number of firms had emerged as dominant, business enterprises took the lead. The USDA became a force in raising productivity in agriculture from the late 19th century, not because its labs did "pure science" that was then made available to farmers, but because experiment stations were set up in connection with land-grant universities in every state of the nation to improve productivity in the particular crops being grown or livestock being raised by the farmers in that state. This interactive model was, as we have seen, institutionalized with the Hatch Act of 1887 that funded experiment stations and the Smith-Lever Act of 1914 that systematized data collection and technology diffusion by funding the cooperative extension system.

Given the existence of millions of family farms - the peak number was 6.8 million in 1935 Government had to take the lead role in the interaction with Business in technology development and diffusion, although the Government-Business relation changed significantly with the rise of agribusiness in the post-World War II decades. With the rise of large-scale enterprise in manufacturing industry from the late 19th century, Business was able to take the lead, and did just that in setting up corporate research labs from the beginning of the $20^{\text {th }}$ century. These labs were established to protect intellectual property and extend innovation in lines of business in which the corporations already had large market shares. Even when they moved into areas of scientific research in which Nobel Prizes in physics or chemistry could be won, they did Applied Research, not Basic Research. And recall that when, during World War II, the U.K. government gave the U.S. government the Whittle jet engine for Development, the U.S. government gave the project to General Electric, not because GE was in the aircraft engine business but because for almost four decades GE Labs had been doing Applied Research on gas turbines in connection with its mainstay business, electric power generation.

\footnotetext{
87 William Lazonick, "Innovative Business Models and Varieties of Capitalism: Financialization of the US Corporation," Business History Review, 84, 4, 2010: 675-702

88 William Lazonick, Business Organization and the Myth of the Market Economy, Cambridge University Press, 911.

89 The text of the National Science Foundation Act can be found at http://www.law.cornell.edu/uscode/text/42/chapter16

90 See Benoît Godin, "The Linear Model of Innovation: The Historical Construction of an Analytical Framework," Science, Technology, and Human Values, 31,6, 2006: 639-667.
} 
Technology development in the military-industrial complex that dominated the U.S. innovation system from the 1940s through the 1960s was based on a highly interactive model of technology development in which the accumulated knowledge base of industrial corporations played the central roles. In some cases such as space exploration that involved highly complex technologies with little prospect of product revenues, government labs did more of the Applied Research and even some of the Development. ${ }^{11}$ In other cases such as the development of integrated circuits where potential mass markets beckoned, Government funded some of the R\&D, much of it through procurement contracts, but it was Business that performed it. 92

\section{c) The New Economy Business Model and the Innovation Crisis}

As was discussed in Section 2, in the 1960s and 1970s the difficulties of discovering how to manufacture high-yield semiconductor chips combined with the potential for huge mass markets for them resulted in the emergence of a whole new type of interactive model in U.S. technology development. In Lazonick's book Sustainable Prosperity in the Economy? Business Organization and High-Tech Employment in the United States, he shows that the rise of the semiconductor industry, centered in Silicon Valley, resulted in the emergence of a "New Economy Business Model" (NEBM) that competed with, and ultimately replaced, the "Old Economy Business Model" (OEBM) in the immediate post-World War II decades had characterized the ICT industries (see Table 6). A business model consists of a) investment strategies in processes and products, b) organizational structures that develop and utilize productive resources, and c) financial commitments that can sustain the business enterprise from the time investments in productive resources are made until the time that through the sale of products financial returns are generated.

Table 6. Strategy, Organization, and Finance, Old Economy Business Model (OEBM) and New Economy Business Models (NEBM) Compared

\begin{tabular}{||l|l|l||}
\hline Strategy, & \multicolumn{1}{|c||}{ OEBM } & \multicolumn{1}{|c||}{ NEBM } \\
\hline product & $\begin{array}{l}\text { Growth by building on internal } \\
\text { capabilities; business expansion } \\
\text { into new product markets based on } \\
\text { related technologies; geographic } \\
\text { expansion to access national } \\
\text { product markets. }\end{array}$ & $\begin{array}{l}\text { New firm entry into specialized } \\
\text { markets; sale of branded com- } \\
\text { ponents to system integrators; } \\
\text { accumulation of new capabilities } \\
\text { by acquiring young technology } \\
\text { firms. }\end{array}$ \\
\hline Strategy, & $\begin{array}{l}\text { Corporate R\&D labs; development } \\
\text { and patenting of proprietary tech- } \\
\text { nologies; vertical integration of the } \\
\text { value chain, at home and abroad. }\end{array}$ & $\begin{array}{l}\text { Cross-licensing of technology } \\
\text { based on open systems; vertical } \\
\text { specialization of the value chain; } \\
\text { outsourcing and offshoring. }\end{array}$ \\
\hline Organization & $\begin{array}{l}\text { Secure employment: career with } \\
\text { one company; salaried and hourly } \\
\text { employees; unions; defined-benefit } \\
\text { pensions; employer-funded } \\
\text { medical insurance in employment } \\
\text { and retirement. }\end{array}$ & $\begin{array}{l}\text { Insecure employment: inter-firm } \\
\text { mobility of labor; broad-based } \\
\text { stock options; nonunion; defined- } \\
\text { contribution pensions; employee } \\
\text { bears greater burden of medical } \\
\text { insurance. }\end{array}$ \\
\hline
\end{tabular}

\footnotetext{
91 See NASA History Program Office at http://history.nasa.gov/

${ }^{92}$ John E. Tilton, International Diffusion of Technology: The Case of Semiconductors, Brookings Institution, 1971.
} 
Who Invests in the High-Tech Knowledge Base?

\begin{tabular}{||l|l|l||}
\hline \hline Finance & $\begin{array}{l}\text { Venture finance from personal } \\
\text { savings, family, and business } \\
\text { associates; NYSE listing; payment } \\
\text { of steady dividends; growth } \\
\text { finance from retentions leveraged } \\
\text { with bond issues. }\end{array}$ & $\begin{array}{l}\text { Organized venture capital; initial } \\
\text { public offering on NASDAQ; low or } \\
\text { no dividends; growth finance from } \\
\text { retentions plus stock as an acqui- } \\
\text { sition currency; stock buybacks to } \\
\text { support stock price. }\end{array}$ \\
\hline
\end{tabular}

Source: Lazonick, Sustainable Prosperity in the New Economy, Upjohn Institute, 2009, p. 17

While the NEBM emerged in the 1960s and 1970s in the industrial region that we now know as Silicon Valley, by the 2000s it had come to dominate the ICT industries, with Old Economy corporations such as IBM and Hewlett-Packard either making the transition to the NEBM or going out of business as independent entities. Table 6, drawn from Lazonick's Sustainable Prosperity book, compares the strategic, organizational, and financial characteristics of OEBM and NEBM. Our view is that the transition from the OEBM to the NEBM fundamentally changed the governance of the U.S. innovation system, both within business enterprises and through the interactions between Households, Government, and Business. It has done so in ways that have undermined investment in the high-tech knowledge base in the United States. In the remainder of this report, we adduce evidence that supports this proposition, with the recognition that much more systematic research to support the hypothesis that the governance of the NEBM has undermined investment in the hightech knowledge base remains to be done. What follows is a brief commentary on the problematic role of the NEBM as an actor in the investment triad, focusing in turn on the strategic, organizational, and financial characteristics of this business model.

\section{Strategy:}

In 1993, a conference held at Harvard Business School (HBS) decried the "end of an era" in industrial research, with a volume Engines of Innovation appearing in $1996 .{ }^{93}$ In the introductory chapter, entitled "Technology's Vanishing Wellspring," conference organizers and volume editors Richard Rosenbloom and William Spencer argued that industrial research (as distinct from development) of the type that had been carried out by corporate labs in the "golden era" of the post-World War II decades "expands the base of knowledge on which existing industries depend and generates new knowledge that leads to new technologies and the birth of new industries." In the more competitive environment of the 1980s and 1990s, however, in the new industries of "biotechnology, exotic materials, and information products (and services based on them)", Rosenbloom and Spencer observed that it was more difficult for companies "to keep new technologies fully proprietary", and hence "research activities have been downsized, redirected, and restructured in recent years within most of the firms that once were among the largest sponsors of industrial research." 94

A participant at the 1993 conference was Gordon Moore, one of the eight Shockley Semiconductor Laboratory employees who left to found Fairchild Semiconductor in 1957. In 1965 Moore, while head of R\&D at Fairchild, enunciated "Moore's Law" (the doubling of the computing power of chips every 18 months), and then in 1968 co-founded Intel with Robert Noyce, who had invented the integrated circuit while at Fairchild. At time of the HBS conference, Moore, formerly Intel's CEO, was its chairman of the board, a position that he held until 1997. When Intel was founded, its top executives expressly eschewed setting up a corporate research lab, and indeed Intel was one of the

\footnotetext{
93 Rosenbloom and Spencer, Engines of Innovation. Richard Rosenbloom was David Sarnoff Professor of Business Administration at Harvard Business School, while William Spencer was CEO of SEMATECH.

94 Ibid., pp. 2-3.
} 
Who Invests in the High-Tech Knowledge Base?

pioneers in creating what I describe as the NEBM. In a paper that he contributed to the Engines of Innovation volume, Moore clearly stated how product development done in New Economy startups was dependent on basic and applied research done in Old Economy corporate labs:

Running with the ideas that big companies can only lope along with has come to be the acknowledged role of the spin-off, or start-up. Note, however, that it is important to distinguish here between exploitation and creation. It is often said that start-ups are better at creating new things. They are not; they are better at exploiting them. Successful start-ups almost always begin with an idea that has ripened in the research organization of a large company. Lose the large companies, or research organizations of large companies, and start-ups disappear. ${ }^{95}$

That was back in the mid-1990s, when the Old Economy corporate research labs were, as we have seen, being quickly run down. As Rosenbloom and Spencer recognized, however, given technological opportunities and global competition, in the 1990s the need for basic and applied research was as important as ever. So, having adopted NEBM, what have the major U.S. high-tech corporations done to gain access to this high-tech knowledge base?

They have looked to Government to provide the funding of Basic Research and Applied Research, done increasingly in Universities, that their business enterprises can then tap. As one early example, SEMATECH, the Nonprofit that Spencer headed from 1990 to 1997, was a research consortium founded in 1987, in response to Japanese competition, to conduct research on U.S. semiconductor manufacturing. Justified as necessary for U.S. defense purposes, SEMATECH was a consortium of the U.S. Department of Defense and 14 U.S. semiconductor companies, with initial funding of $\$ 100$ million per year for five years from DoD matched by $\$ 100$ million per year from Business, which included Intel.96

U.S. high-tech companies lobby the U.S. government to fund the research that their companies need, citing U.S. competitiveness as the rationale for government support. For example, Intel executives have long lobbied the U.S. government to increase spending on nanotechnology research, arguing as its then-CEO Craig R. Barrett did in 2005 that "it will take a massive, coordinated U.S. research effort involving academia, industry, and state and federal governments to ensure that America continues to be the world leader in information technology." 97 In fact, from its launching 2001 through 2013 the National Nanotechnology Initiative (NNI) aggregated funding from 11 U.S. government agencies, including primarily DoE, DHHS, NSF, and DoD, to channel $\$ 15.6$ billion to nanotechnology research. 98 The estimated NNI budget for 2014 is $\$ 1.5375$ billion, and the proposed budget for 2015 is $\$ 1.5369$ billion.

As another example, the American Energy Innovation Council (AEIC), an association of six corporate executives who have led seven major companies - Bank of America, Cummins, DuPont, General Electric, Lockheed, Microsoft, and Xerox - and venture capitalist John Doerr of Kleiner, Perkins, Caufield, \& Byers, has lobbied the U.S. government to triple its investment in alternative-

95 Gordon E. Moore, "Some Personal Perspectives on Research in the Semiconductor Industry," in S. Rosenbloom and Spencer, Engines of Innovation, p. 171.

${ }^{96}$ Briefing Report to the Chairman, Subcommittee on Defense, Committee on Appropriations, U.S. Senate, "Federal Research, SEMATECH's Technological Progress and Proposed R\&D Program," General Accounting Office, July 1992. The 14 original SEMATECH members were Advanced Micro Devices, AT\&T, Digital Equipment Corporation, Harris, HewlettPackard, IBM, Intel, LSI Logic, Micron Technology, Motorola, National Semiconductor, NCR, Rockwell International, and Texas Instruments.

97 "U.S. could lose race for nanotech leadership, SIA panel says" EDN Network, March 16, 2005, at http://www.edn.com/electronics-news/4326508/U-S-Could-Lose-Race-for-Nanotech-Leadership-SIA-Panel-Says.

98 National Nanotechnology Initiative, NNI Budget at http://www.nano.gov/about-nni/what/funding 
Who Invests in the High-Tech Knowledge Base?

energy research and subsidies to $\$ 16$ billion per year. ${ }^{99}$ In an AEIC press release in 2010, Doerr stated:

When our company [Kleiner Perkins] shifted our attention to clean energy, we found the innovation cupboard was close to bare. America has simply neglected to support serious energy innovation. My partners and I found the best fuel cells, the best energy storage, and the best wind technologies were all born outside the United States. Other countries are investing huge amounts in these fields. Without innovation, we cannot build great energy companies. We need to restock the cupboard or be left behind. 100

Yet Lazonick's research suggests that, as these companies have lobbied the U.S. government for more research funding, they are not making the necessary complementary commitments to doing such funding themselves. Rather they have been spending billions of dollars buying back their own stock, in an effort to boost their stock prices.101 For example, while, as we have seen, Intel has lobbied the U.S. government for more spending on nanotechnology research, the $\$ 70.2$ billion that Intel, as just one company, spent on stock buybacks from 2001 through 2013 was 4.5 times the entire NNI budget over that period. The seven companies whose top executives are members of AEIC could have quadrupled U.S. government spending on alternative technology for the decade 2001-2010 with the $\$ 237$ billion that their companies spent on buybacks over that period.

In 1994, at a time when most U.S. Old Economy research labs had all but disappeared, Rebecca Henderson, at the time an associate professor of strategic management at MIT, wrote an article in Harvard Business Review, "Managing Innovation in the Information Age," in which she touted the exemplary corporate research of pharmaceutical companies, arguing that "the longevity of pharmaceutical companies attests to a unique management competency: the ability to foster a high level of specialized knowledge within an organization, while preventing that information from becoming embedded in such a way that it permanently fixes the organization in the past, unable to respond to an ever-changing competitive environment." 102 Yet over the past decade there has been a discussion of the "productivity crisis" in drug discovery. ${ }^{103}$ A major part of the problem is that leading U.S. pharmaceutical companies such as Merck and Pfizer have been spending the last two decades living off their patented drugs, with very little to replace them in the pipeline. 104

${ }_{99}$ AEIC website: http://americanenergyinnovation.org/principals/; John M. Broder, "A call to triple U.S. spending on energy research," New York Times, June 9, 2010, p. B3; Lazonick, “The Financialization of the U.S. Corporation,” pp. 890891.

100 American Energy Innovation Council, "American Business Leaders Call for Revolution in Energy Technology Innovation," Press Release June 10, 2010, at http://americanenergy innovation.org/press-release-call-for-revolutionin-energy-tech-innovation/.

101 William Lazonick, "Taking Stock: Why Executive Pay Results in an Unstable and Inequitable Economy," Roosevelt Institute White Paper, June 5, 2014; William Lazonick, "Labor in the Twenty-First Century: The Top 0.1\% and the Disappearing Middle Class," AIR Working Paper \#2014-08/01. August 2014; William Lazonick, "Profits Without Prosperity: Stock Buybacks Manipulate the Market and Leave Most Americans Worse Off," Harvard Business Review, September 2014: 46-55.

102 Rebecca Henderson, "Managing Innovation in the Information Age," Harvard Business Review, January-February 1994 : 100-107, quoted at p. 100.

103 See Gary Pisano, Science Business:: The Promise, the Future, and the Reality of Biotech, Harvard Business School Press, 2006; Iain Cockburn, "Is the Pharmaceutical Industry in a Productivity Crisis?," in Josh Lerner and Scott Stern, eds., Innovation Policy and the Economy, Volume 7, MIT Press 2007: 1-32; Fabio Pammolli, Laura Magazzini, and Massimo Riccaboni, "The Productivity Crisis in Pharmaceutical R\&D," Nature Reviews, Drug Discovery, 10, 6, 2011: 428-438; Ish Khanna, "Drug Discovery in Pharmaceutical Industry: Challenges and Trends," Drug Discovery Today, 17, 19/20, 2012; Jack DeRuiter and Pamela J. Holston, "Drug Patent Expirations and the 'Patent Cliff'," U.S. Pharmacist, 37, 6, 2012: 12-20 at http://www.uspharmacist.com/content/s/216/c/35249/.

104 David J. Phillips, "Pfizer's pipeline story begins to unravel," YCharts, August 30, 2013, at http://finance.yahoo.com/news/pfizer-pipeline-story-begins-unravel-143509405.html; Maggie McGrath, "Drug patent 
The deterioration in the research capabilities of U.S. drug companies has occurred despite the fact that pharmaceutical drug prices are double in the United States what they might be in any other advanced nation. When Congress and the media have challenged the drug companies on this pricing policy, they have responded that they need to charge high prices in the United States to fund the high levels of R\&D that they do in this country. ${ }^{105}$ The fact is however, that, these companies have been spending a very high proportion of their profits on stock buybacks to prop up their stock prices. As a prime example of big pharma, for the two decades 1994-2013 Pfizer expended 66\% of net income on buybacks and another $60 \%$ on dividends. During the decade 2004-2013 it spent $60 \%$ on buybacks and $63 \%$ on dividends. In the case of Amgen, the leading biopharma company, for the two decades 1994-2013 it expended 103\% of net income on buybacks and another $7 \%$ on dividends. During the decade 2004-2013 it spent $100 \%$ if net income on buybacks and $8 \%$ on dividends.

Meanwhile these drug companies are able to avail themselves of the knowledge generated by the research funded by the $\mathrm{NIH}$, with its annual budget of $\$ 29$ billion to $\$ 31$ billion in recent years. Most of the NIH research is done in Universities or Nonprofits, but, as we have seen, the Bayh-Dole Act of 1980 encouraged and facilitated the transfer of the results of Government research to Business, and indeed many $\mathrm{NIH}$-funded scientists at Universities and Nonprofits have substantial financial interests in companies that seek to develop products based on the NIH-funded research that these scientists do. ${ }^{106}$ Indeed, an area for future study is to what extent NIH funds are now supporting Development activities at Universities and Nonprofits that business enterprises should be doing on their own.

In discussions of the dismantling of U.S. corporate research capabilities in the 1990s, among which the Rosenbloom-Spencer volume Engines of Innovation is the most sophisticated contemporary example, the main reason given was that new competitive conditions made it more difficult to maintain previous profit margins and retain proprietary control over intellectual property. The rise of the NEBM in the ICT industries certainly created these new conditions as did the rise of Japanese competitors in a range of industries, including automobiles, consumer electronics, semiconductors, machine tools, and steel, in which, in the 1970s, the United States had been the world leader.107 But of much more long lasting damage to U.S. innovation was the ideological response to the new competition by both financial economists and Wall Street financial interests in the last half of the 1980s, namely the credo that corporations should be run to "maximize shareholder value" (MSV). ${ }^{108}$

As Lazonick has shown, MSV is a theory of corporate governance that legitimizes a "downsize-anddistribute" corporate resource-allocation regime: U.S. corporations often do large-scale layoffs, especially of older, more expensive employees, and distribute the so-called "free" cash flow to shareholders via buybacks and dividends. Over the decade 2004-2013, 454 companies in the S\&P 500 Index in March 2014, with a combined \$9.6 trillion in revenues and 24 million employees worldwide, expended $\$ 3.4$ trillion on buybacks, representing $51 \%$ of net income, and another $\$ 2.3$

expirations continue to hit Pfizer revenue," Forbes, January 28, 2014; Maggie McGrath, "Merck sales slide on expiring drug patents but shares lifted by cancer-fighting collaboration," Forbes, February 5, 2014;

105 William Lazonick and Öner Tulum, "US Biopharmaceutical Finance and the Sustainability of the Biotech Business

Model," Research Policy, 40, 9, 2011: 1170-1187.

106 Sheldon Krimsky, Science in the Private Interest: Has the Lure of Profits Corrupted Biomedical Research?, Rowan \& Littlefield, 2004.

107 Lazonick, "Innovative Business Models."

108 William Lazonick and Mary O’Sullivan, "Maximizing Shareholder Value: A New Ideology for Corporate Governance,”

Economy and Society, 29, 1, 2000: 13-35. 
Who Invests in the High-Tech Knowledge Base?

trillion on dividends, absorbing an additional 35\% of net income. Companies have tended to do buybacks when stock prices are high, contradicting the oft-heard claim from corporate executives that their companies do buybacks when the stock market undervalues their shares.

Why do top executives do all those stock buybacks? In an article in Harvard Business Review, Lazonick systematically rejects the usual arguments that corporate executives and financial economists give for justifying open-market stock repurchases (which represent the vast majority of buybacks). He shows that the only purpose of open-market repurchases is to give manipulative (and inevitably temporary) boosts to a company's stock price. He also provides strong evidence that the top executives who make these buyback decisions can benefit personally from this financial behavior because of their stock-based pay. As shown in Table 7 for the 500 highest paid U.S. corporate executives named in company proxy statements, since 2006 average total compensation (in current dollars) ranged from $\$ 14.4$ million in 2009 (when the stock market had collapsed) to $\$ 30.3$ million in 2012 (with the stock market booming), with the proportion of total compensation derived from actual gains of stock-based pay (stock options and stock awards) ranging from $66 \%$ in 2009 to $82 \%$ in 2012.109

Table 7. Mean Total Direct Compensation of the 500 Highest-Paid Executives Named in U.S. Corporate Proxy Statements, and the Components of Total Direct Compensation, 2006-2012

\begin{tabular}{|r|r|r|r|r|r|r|r|r|}
\cline { 3 - 9 } & \multicolumn{3}{|c|}{ Percentage shares of components of total direct compensation } \\
\hline & $\begin{array}{c}\text { Mean } \\
\text { Total } \\
\text { Direct } \\
\text { Comp. \$m. }\end{array}$ & Salary & Bonus & $\begin{array}{c}\text { Non- } \\
\text { Equity } \\
\text { Incentive } \\
\text { Plan }\end{array}$ & $\begin{array}{c}\text { All Other } \\
\text { Comp. }\end{array}$ & $\begin{array}{c}\text { Realized } \\
\text { Deferred } \\
\text { Earnings }\end{array}$ & $\begin{array}{c}\text { Sealized } \\
\text { Option } \\
\text { Gains } \\
\text { Stock } \\
\text { Award } \\
\text { Gains }\end{array}$ \\
\hline $\mathbf{2 0 0 6}$ & $\mathbf{2 7 . 4}$ & 3.3 & 7.0 & 7.6 & 5.9 & 0.5 & 58.9 & 16.8 \\
\hline $\mathbf{2 0 0 7}$ & $\mathbf{3 0 . 0}$ & 3.0 & 4.1 & 6.9 & 7.6 & 0.1 & 58.8 & 19.6 \\
\hline $\mathbf{2 0 0 8}$ & $\mathbf{2 2 . 9}$ & 4.1 & 4.2 & 8.7 & 4.1 & 0.1 & 43.9 & 34.9 \\
\hline $\mathbf{2 0 0 9}$ & $\mathbf{1 4 . 4}$ & 7.0 & 4.8 & 14.9 & 7.4 & 0.1 & 39.9 & 25.9 \\
\hline $\mathbf{2 0 1 0}$ & $\mathbf{1 8 . 5}$ & 5.5 & 4.8 & 15.0 & 6.2 & 0.1 & 40.3 & 28.1 \\
\hline $\mathbf{2 0 1 1}$ & $\mathbf{1 9 . 4}$ & 5.5 & 3.8 & 12.3 & 4.3 & 0.2 & 40.9 & 33.0 \\
\hline $\mathbf{2 0 1 2}$ & $\mathbf{3 0 . 3}$ & 3.6 & 2.7 & 8.2 & 3.2 & 0.1 & 41.5 & 40.7 \\
\hline
\end{tabular}

Source: Standard and Poor's ExecuComp database, with calculations by Matt Hopkins, The Academic-Industry Research Network

Given the importance of stock-based pay in compensation packages, a booming stock market boosts executive pay. Companies can use open-market repurchases to give a manipulative boost to stock prices, or to try to prevent their fall. But even when a company's stock price falls, U.S.-style stockbased pay can enable executives to gain. In a stock-market downturn, the board of directors stuffs even more stock options and stock awards into top-executive pay packages to make sure that senior executives will be amply incentivized to do whatever is necessary to boost the company's stock price back up. To manage this stock-price manipulation, they can turn to massive stock buybacks.

Note that it is the massive buybacks, not outsized executive pay that is the immediate cause of damage to corporate innovation and job creation. Reducing the CEO:average-worker pay ratio will

\footnotetext{
109 For an analysis of the process by which compensation is set, and how stock-based pay ratchets up executive compensation even when stock prices fall, see William Lazonick, "Taking Stock" Roosevelt Institute, June 5, 2014, at http://rooseveltinstitute.org/sites/all/files/Lazonick_Executive_Pay_White_Paper_Roosevelt_Institute.pdf
} 
Who Invests in the High-Tech Knowledge Base?

not undo the damage done by buybacks unless the control of CEO pay takes away the incentives of executives to engage in this financialized behavior. More than that, we would hypothesize that the corporate executives who are willing to expend hundreds of millions or, as is often the case, billions of dollars per year on open-market repurchases cannot possibly have the strategic vision of the types of collective and cumulative learning of which the company that he or she controls is capable. Yet, especially in high-tech companies in which a sophisticated knowledge base has accumulated in the past and hence the potential to engage in the next generation of innovation is the greatest, if the executives who make corporate resource-allocation decisions lack a strategic vision of nextgeneration innovation, the possibility that the business enterprise will remain or become a leading innovator is reduced to zero.

\section{Organization:}

Of paramount importance to the collective and cumulative learning processes that can result in innovation are collective and cumulative careers. While knowledge that is learned can be codified as a platform for further learning, it is the tacit knowledge of people with specialized capabilities in organizations intent on innovation that can take learning process to a more advanced stage. ${ }^{110}$ Under OEBM, it was the norm of a career with one company that provided the employment institution that enabled collective and cumulative careers. Although, with the rise of Japanese competition to U.S. industry from the mid-1970s, many Americans (including most academic economists with tenured positions) saw the institution of "lifetime employment" as peculiarly Japanese, in fact in the post-World War II decades, long before the Japanese were recognized as a competitive threat, virtually all major U.S. industrial corporations had adopted the norms of a career with one company for their professional, technical, and administrative employees. ${ }^{111}$ In competition, for college graduates, established American companies offered prospective employees the realistic possibility of a career with the company, culminating in a defined-benefit pension at the end of, typically, 30 years. Having attracted young college graduates, these companies expended resources to train them (formally and on-the-job), and having trained them, instituted internal promotion ladders to retain them. The most promising among them would then be transformed from specialists to generalists as they moved around and up the managerial hierarchy. In the process the OEBM rewarded these employees through salary increases tied to promotions within a well-defined corporate pay structure. 112

This form of collective and cumulative learning based on the norm of a career with one company was ideally suited to the accumulation of a knowledge base related to proprietary technologies in oligopolistic industries with a stable number of competitors. It persisted at U.S. Old Economy companies into the 1980s, but during that decade was disrupted by the rise of two very different forms of competition. One form was from the Japanese who, in effect, perfected the U.S. Old Economy business model by pushing collective and cumulative learning based on the norm of a career with one company from the managerial structure, where it existed in U.S. companies, to the shop floor, where it did not. The organizational integration of shop-floor workers into collective and cumulative learning processes provided the foundation for Japanese manufacturing prowess in industries such as consumer electronics, automobiles, and memory chips in which during the 1980s

\footnotetext{
110 See the model of collective and cumulative learning in Ikujiro Nonaka, "The Knowledge-Creating Company," Harvard Business Review, November-December 1991: 96-104; Ikujiro Nonaka and Hirotaka Takeuchi, The Knowledge-Creating Company: How Japanese Companies Create the Dynamics of Innovation, Oxford University Press, 1995.

111 Lazonick, Sustainable Prosperity, ch. 3.

112 William Lazonick, "Strategy, Structure, and Management Development in the United States and Britain," in K. Kobayashi and H. Morikawa, eds., Development of Managerial Enterprise, University of Tokyo Press, 1986: 101-146.
} 
the Japanese were able to out-innovative their formerly world-class U.S. counterparts. ${ }^{113}$

In consumer electronics, Japanese competition quickly drove U.S. companies out of business. For example, in 1981, RCA, with 119,000 employees, was one of the leading consumer electronics companies in the world and the 44th largest U.S. industrial company by revenues. ${ }^{114}$ By 1986 , it had been taken over by General Electric, and was then sold off in pieces, one of which was the David Sarnoff Research Center, RCA's corporate research lab that had been launched in 1941 and that had invented color television in the late 1940s and early 1950s and the liquid crystal display in the late 1960s. 115

During the 1980s, U.S. automobile manufacturers attempted to learn from the Japanese, with the first significant collaboration being the NUMMI joint-venture begun in 1984 in an unused GM car plant in Oakland, California (the joint-venture officially ended in 2009, and in 2010, Tesla Motors took over the NUMMI plant to produce electric cars). In 1985 GM launched Saturn in a greenfield plant in Spring Hill, Tennessee with the specific purpose of adopting Japanese management methods. But despite the success of Saturn in compact cars, GM decided not to expand it to mid-size cars, largely because the parent company did not want Saturn competing with its internal car divisions. In 2009 GM definitively shuttered Saturn, and still producing lower quality, higher cost cars than the Japanese, had to turn to the U.S. government to be bailed out of bankruptcy.116 In fact, what got GM out of bankruptcy was its success in the Chinese car market, in a joint-venture with the City of Shanghai, selling German Opels and Korean Daiwoos that were marketed as Buicks.117

The most perilous, but ultimately successful, U.S. response to Japanese competition was in the semiconductor industry. By the middle of the 1980s, the Japanese had used their integrated skill bases to lower defects and raise yields in the production of memory integrated circuits, transforming one of the most revolutionary technologies in history into mass-produced goods known as "commodity chips". This development forced major U.S. semiconductor companies to retreat from the memory segment of the market, with Intel, a key U.S. chip company, facing the possibility of bankruptcy in the process. ${ }^{118}$

Since 1981, however, Intel had been producing microprocessors for the IBM PC and its clones, and on this basis emerged by the beginning of the 1990s as the world's leading chip manufacturer. More generally, during the 1980s, as the Japanese (and then the South Koreans) were taking over the memory-chip market, U.S. companies became world leaders in the production of logic integrated circuits, where value was added through chip design rather than manufacturing yield, the area in which the Japanese now excelled. Indeed, relying on the Intel microprocessor and the Microsoft

113 William Lazonick, “Organizational Learning and International Competition," in J. Michie and J. G. Smith, eds., Globalization, Growth, and Governance, Oxford University Press, 1998: 204-238

114 Alfred D. Chandler, Jr., Inventing the Electronic Century: The Epic Story of the Consumer Electronics and Computer Industries, Free Press, pp. 13-49.

115 See IEEE Global History Network: http://www.ieeeghn.org/wiki/index.php/Milestones:MonochromeCompatible_Electronic_Color_Television,_1946-1953; and http://www.ieeeghn.org/wiki/index.php/Milestones:Monochrome-Compatible_Electronic_Color_Television,_19461953

116 Michaela D. Platzer and Glennon J. Harrison, "The U.S. Automotive Industry: National and State Trends in manufacturing Employment," Congressional Research Service, R40746, 2009, at http://digitalcommons.ilr.cornell.edu/key_workplace/666.

117 Michael J. Dunne, American Wheels, Chinese Roads: The Story of General Motors in China, Wiley, 2011.

118 Robert A. Burgelman, "Fading Memories: A Process Theory of Strategic Business Exit in Dynamic Environments," Administrative Science Quarterly, 39, 1, 1994: 24-56; Daniel I. Okimoto and Yoshio Nishi. "R\&D Organization in Japanese and American Semiconductor Firms," in Masahiko Aoki and Ronald Dore, eds., The Japanese Firm: The Sources of Competitive Strength, Oxford University Press, 1994:178-208. 
Who Invests in the High-Tech Knowledge Base?

operating system, the rapid emergence of the IBM PC as the industry "open systems" - or "Wintel" standard in the years after its launch in 1981, was the basis for the rise of a "New Economy business model" in ICT.119

The rise and expansion of NEBM had profound impacts on the employment of labor in high-tech companies. Silicon Valley startups could not offer professional, technical, and administrative employees the promise of a career with one company, but they could offer them employee stock options which could become valuable if the firm could make it to an IPO on NASDAQ, the speculative electronic stock market launched in 1971. As successful NEBM companies did IPOs and expanded, they continued the practice of offering stock options as partial compensation to some or all of their U.S. employees. As a result, employment under NEBM turned high-tech employees into the potential beneficiaries of increases in the company's stock price. Given that from 1982 to 2000 the U.S. stock market had the longest boom in is history, the gains from exercising stock options could be substantial. ${ }^{120}$

As a major example, from 1995 to 2000 Cisco Systems expanded from its employment from 4,100 to 34,000 worldwide as it came to dominate the Internet equipment market. Its stock price rose rapidly to August 1998, reflecting its innovative success. Then, stock-market speculators discovered Cisco, and in the dot.com bubble of 1998-2000, Cisco's stock price soared. By March 2000 Cisco had the highest market capitalization of any company in the world. As a result of this boom, the average gains per Cisco employee from exercising stocks options (not including the five highest-paid executives named on proxy statements) were (rounding off to the nearest thousand) $\$ 61,000$ in 1995, \$93,000 in 1996, \$85,000 in 1997, \$93,000 in 1998, \$193,000 in 1999, and \$291,000 in 2000. When the stock market crashed so did the stock-option gains of Cisco employees, amounting to "only" $\$ 14,000$ in 2002 , but then, on the eve of the financial crisis, moving up to $\$ 73,000$ in 2007 (when Cisco had 61,500 employees).121

Although the data are only fragmentary, we think that the competition for high-tech personnel by New Economy companies offering potentially large gains from stock options as an alternative to the OEBM promise of secure and remunerative career-with-one-company employment contributed to the demise of the corporate research labs from the late 1980s, as some lab personnel opted for NEBM (stock-option gains) rather than OEBM (secure employment). The departure of experienced Old Economy personnel to join New Economy companies disrupted the organizational learning processes that are the essence of innovation in the research process. The consequent loss of intellectual property and poor performance of research processes left the Old Economy labs vulnerable to the chopping block, especially in an era in which the ascendant ideology was MSV.

Given its size, reputation, and central position in the ICT industries, the dramatic changes at IBM in the early 1990s marked a fundamental juncture in the transition from Old Economy employment security to New Economy employment insecurity in the U.S. corporate economy. Through the 1980s IBM touted its practice of "lifelong employment" as a source of its competitive success. From 1990 to 1994 , however, IBM cut employment from 373,816 to 219,839 , reducing its labor force to only 59 percent of its year-end 1990 level. During this period, much of IBM's downsizing was accomplished by making it attractive for its employees to accept voluntary severance packages, including early retirement at age 55. But in 1993 and 1994, after recruiting CEO Louis V. Gerstner,

119 Lazonick, Sustainable Prosperity, ch. 2.

120 Ibid.; See also William Lazonick, "The New Economy Business Model and the Crisis of US Capitalism," Capitalism and Society, 4, 2, 2009: article 4.

121 Lazonick Sustainable Prosperity, p. 64. Note that the information in corporate financial statements from which these calculations are derived only became available in fiscal 1994 or 1995. 
Who Invests in the High-Tech Knowledge Base?

Jr. from RJR Nabisco to get the job done, many thousands of IBM employees were fired outright. In 1995 IBM rescinded the early-retirement offer that had helped downsize its labor force; the offer had accomplished its purpose, and in any case, IBM no longer wanted to encourage all employees to remain with the company even until the age of 55.122

The transformation of employment relations at IBM was not about cost-cutting in the face shrinking revenues in the early 1990s recession and a declining mainframe computer market, as has typically been portrayed. It was about the fact that, through its leading role in creating the open-systems "Wintel" standard in the information-technology industry, IBM no longer placed the same value on older employees who were experienced in its proprietary technologies. Now the company was more interested in employing younger personnel who had the latest programming skills, perhaps acquired working for New Economy companies. It did not hurt that these younger workers would also come cheaper than the lifelong employees to whom IBM was now showing the door. Of IBM's losses of $\$ 15.9$ billion in 1991-1993 (including an $\$ 8.1$ billion deficit in 1993 , the largest annual loss in U.S. corporate history at the time), 86 percent came from workforce-related restructuring charges (including the cost of employee separations and relocations). This loss was, in effect, the cost to the company of ridding itself of its once-hallowed tradition of lifelong employment. Other restructuring charges, mainly for the consolidation of manufacturing capacity and elimination of excess space - both part and parcel of the massive downsizing process - amounted to $\$ 10.6$ billion over the same three years. Ignoring restructuring charges, IBM recorded positive net incomes before taxes of \$939 million in 1991, \$2,619 million in 1992, and \$148 million in 1993.

Meanwhile IBM also dismantled its corporate research capability. IBM's R\&D expenditures as a percent of sales averaged $7.1 \%$ from 1981 to 1993 , but only $5.6 \%$ from 1994 to 2007 . As IBM was cutting its R\&D, the company became the leading patenter in the world. The main point of patenting was not, however, to protect proprietary technologies but rather, in a NEBM world, to engage in cross-licensing of technologies and to generate intellectual-property revenues from its patent portfolio. ${ }^{123}$ By the last half of the 1990s, IBM had made the transition from the OEBM to the NEBM.

The emergence of a highly mobile high-tech labor force made it difficult for New Economy high-tech companies to engage in significant organizational learning, even for companies that sought to do so. As a prime example, in 1991 Microsoft launched an OEBM-style corporate research lab, Microsoft Research, and the facility still exists. ${ }^{124}$ But in over two decades, no significant technological advances have come out of Microsoft Research. In the late 1990s, many key people were leaving the company, attracted by high-tech startups and disruptive R\&D processes. It is said that in 2000, when the company had 39,100 employees worldwide, there were 10,000 Microsoft millionaires created from the exercising of employee stock options, a plausible number given that the average gains from exercising stock options at the company were $\$ 370,000$ in 1999 and $\$ 449,000$ in $2000 .{ }^{125}$ These were only the average gains; some employees made millions and even tens of millions of dollars from stock options in these years, and thus enriched they were apt to leave Microsoft to start their own firm, take a potentially lucrative stock-based offer with another company, or even retire at a young age. In our view, the much-publicized anti-poaching agreements the mid-2000s among Silicon Valley CEOs including those at Apple, Google, Intel, and Adobe were less about suppressing wages as the legal case has been portrayed by lawyers and the press and

\footnotetext{
122 Lazonick, Sustainable Prosperity, pp. 83-89.

123 Lazonick, Sustainable Prosperity, pp. 83-89.

$124 \mathrm{http}: / /$ research.microsoft.com/en-us/. According to a post on Glassdoor, average compensation at Microsoft Research is $\$ 173,000$, of which $\$ 131,000$ is salary: http://www.glassdoor.com/Salary/Microsoft-Researcher-SalariesE1651_D_K010,20.htm

125 Lazonick. Sustainable Prosperity, p. 64.
} 
more about protecting product development processes from disruption because of the loss of key people to other firms. ${ }^{126}$

The high degree of the interfirm mobility of high-tech labor, especially during economic booms, is a major reason why U.S. high-tech employers value the availability of university-educated workers who are working in the United States on temporary non-immigrant visas. These foreign workers have no possibility of changing jobs while in the United States. Since the 1990s vast numbers of college-educated Asians, first and foremost from India, have found employment in the United States under H-1B and L-1 temporary immigrant visa programs. ${ }^{127}$ The majority of workers on temporary work visas computer-related college degrees, and many of them have acquired further higher education in high-tech fields in the United States before being employed on an H-1B or L-1 visa. Many employees on $\mathrm{H}-1 \mathrm{~B}$ and $\mathrm{L}-1$ visas transition to permanent immigration visas in the United States, but most have gone back to their countries of origin with enhanced education and experience that are extremely valuable for developing innovative capabilities there.128 Indeed, Indian IT companies such as TCS, Infosys, and Wipro have been among the largest users of H-1B and L-1 visas as they employ Indians in the United States to acquire more sophisticated capabilities that can be "near-shored" back to India to support the movement of their companies up global value chains. ${ }^{129}$

These technology transfers, undertaken both by companies from developing countries such as China and India as well as by U.S. multinational enterprises operating in those countries have been important for the accumulation of the knowledge base abroad. But contrary to the arguments made in all of the studies of the U.S. "innovation crisis" that we quoted at the beginning of this section, we do not see this globalization of the innovation process as the source of the innovation crisis in the United States. Rather, as indicated above in our discussion of "strategy" and as will be elaborated below in our discussion of "finance", the problem is the failure of U.S. industrial corporations to use profits secured from the global economy to invest in higher value-added learning processes at home. 130

These flows of high-tech activities abroad pertain primarily to the ICT industry, which since the expansion of the semiconductor industry in the 1960s has offshored more routine manufacturing activities (specifically assembly and testing) to Asian nations. ${ }^{131}$ Very different problems of organizational learning exist in the biomedical sector in which companies, including large numbers of small research entities without commercial products, rely heavily on NIH funding through Universities to generate products. ${ }^{132}$ Since the late 1970s, when the Silicon Valley NEBM was transferred (in our view inappropriately) to biotechnology, key shareholders, executives, and board members in the biopharma companies have been scientists working in university research labs. In

\footnotetext{
126 Howard Mintz, “Apple, Intel, Google likely conspired to not poach workers, judge rules," San Jose Mercury News, April 5, 2013: Joel Rosenblatt, "Apple could fix rejected anti-poaching deal on the cheap," Bloomberg BusinessWeek, August 28, 2014 at http://www.businessweek.com/news/2014-08-28/apple-could-fix-rejected-anti-poaching-deal-for-pocketchange

127 Lazonick, Sustainable Prosperity, ch. 5. See the website of Norm Matloff: http://heather.cs.ucdavis.edu/h1b.html.

128 Ron Hira, "Bridge to Immigration or Cheap Temporary Labor? The H-1B \& L-1 Visa Programs Are a Source of Both," Economic Policy Institute Briefing Paper \#257, February 17. 2010.

${ }^{129}$ For the top H-1B visa holders in 29014, see http://www.myvisajobs.com/Reports/2014-H1B-Visa-Sponsor.aspx; for L-1 visas, see Deepak Chitnis, "USCIS to increase scrutiny of Indian IT firms, L-1 visa holders will be under the scanner," The American Bazaar, January 28, 2014, at http://www.americanbazaaronline.com/2014/01/28/uscisincrease-scrutiny-indian-firms-l-1-visa-holders-will-scanner/.

130 Lazonick, "Labor in the Twenty-First Century,"

${ }^{131}$ Lazonick, Sustainable Prosperity, ch. 5

132 Lazonick and Tulum, "U.S. Biopharmaceutical Finance."
} 
an industry that more than almost any other requires sustained collective and cumulative learning to generate a commercial product - in this case one that will mitigate a disease without killing the patient - strong financial incentives have long been in place among scientific personnel to keep scientific knowledge to themselves. ${ }^{133}$

As Sheldon Krimsky, a longtime critic of Business-University interaction in biomedical science, has put it, the incentives that the commercialized research system creates for large fortunes flowing to a few has created an "unseemly" academic environment in which "university science becomes entangled with entrepreneurship; knowledge is pursued for its monetary value; and expertise with a point of view can be purchased."134 The problem in our view is not just one of morality. Our ongoing study of the biopharma industry strongly supports the hypothesis that by undermining organizational learning as well as by often rewarding value extraction (e.g., stock-based executive compensation) even in the absence of value creation (i.e., a commercial product), the current Business-University interaction in the R\&D process undermines innovation. ${ }^{135}$

\section{Finance}

We have already argued that, given the centrality of Business in driving interactions with Government and Households in the Investment Triad, the major challenge that faces the U.S. innovation system is the financialization of the industrial corporation. The main manifestation of financialization is the massive flow of cash from corporations to the stock market in the form of open-market stock repurchases. To repeat, in the decade 2004-2013, 454 companies in the S\&P 500 Index expended $\$ 3.4$ trillion on buybacks, representing 51\% of net income, and another $\$ 2.3$ trillion on dividends, absorbing an additional $35 \%$ of net income.

Table 8 shows the 25 largest stock repurchasers in the United States for the decade 2004-2013. For 15 of the companies in Table 8, distributions to shareholders over the decade were $100 \%$ or more of net income. The combined payout ratios for petroleum-refining and financial companies were (with the exception of Bank of America) under 100\%, despite huge payouts, because their profits were so high.

What, we can ask, are the implications of these distributions to shareholders to the operation and performance of these companies? The previous discussion in the report should have alerted the reader to the general answer: The only way we know the impacts in particular cases is through indepth research of particular companies that compete in different industries, characterized by different technologies, markets, and competitors.

The top 25 repurchasers in Table 8 are in a wide range of industries, including eight in ICT, three in pharmaceutical drugs, and three in petroluem refining. There are vast difference in the dynamics of innovation and competition across these industries that can only be understood through expert knowlege of the technological challenges they face, the types of markets they serve, and differences in strategy and structure among the main competitors in the industry both at home and abroad. That having been said, with an appropriate analytical framework - the one we use is called "the

\footnotetext{
133 Susan Wright, “Recombinant DNA Technology and Its Social Transformation, 1972-1982,” Osiris, 2nd ser., 2: 303-360.

134 Sheldon Krimsky, Science in the Private Interest: Has the Lure of Profits Corrupted Biomedical Research? Rowan and Littlefield, 2003, p. 3.

135 See Lazonick and Tulum, "U.S. Biopharmaceutical Finance" as well as work-in-progress at The Academic-Industry Research Network.
} 
Who Invests in the High-Tech Knowledge Base?

theory of innovative enterprise" - it is possible to study complex organizations operating in a complex institutional environment, and come up with conclusions based on the evidence. ${ }^{136}$

136 For the most recent articulation of the analytical framework see William Lazonick, "The Theory of Innovative Enterprise: A Foundation of Economic Analysis," AIR Working Paper \#13-05-01, May 2013 at http://www.theairnet.org/files/research/WorkingPapers/Lazonick_InnovativeEnterprise_AIR-WP13.0501.pdf.

Applications of the theory at the company level include Lazonick and Prencipe, "Dynamic Capabilities and Sustained Innovation"; William Lazonick and Edward March, "The Rise and Demise of Lucent Technologies," Journal of Strategic Management Education, 7, 4, 2011; William Lazonick, Mariana Mazzucato, and Öner Tulum, "Apple's Changing Business Model: What Should the World's Richest Company Do With All Those Profits?" Accounting Forum, 37, 4, 2013: 249-267. 
Who Invests in the High-Tech Knowledge Base?

Table 8. Top 25 stock repurchasers, 2004-2013, with percentages of net income (NI) spent on repurchases (RP) and dividends (DV)

\begin{tabular}{|c|c|c|c|c|c|c|}
\hline $\begin{array}{c}\text { Buyback } \\
\text { rank }\end{array}$ & Company Name & RP \$b. & DV \$b & $\begin{array}{c}\text { RP/NI } \\
\% \\
\end{array}$ & $\begin{array}{c}\text { DV/NI } \\
\% \\
\end{array}$ & $\begin{array}{c}(\mathrm{DV}+\mathrm{RP}) \\
/ \mathrm{NI} \\
\% \\
\end{array}$ \\
\hline 1 & EXXON MOBIL & 217 & 84 & 60 & 23 & 84 \\
\hline 2 & IBM & 116 & 26 & 92 & 21 & 113 \\
\hline 3 & MICROSOFT & 113 & 77 & 71 & 48 & 119 \\
\hline 4 & CISCO SYSTEMS & 72 & 5 & 103 & 8 & 110 \\
\hline 5 & PROCTER \& GAMBLE & 71 & 47 & 71 & 47 & 118 \\
\hline 6 & HEWLETT-PACKARD & 65 & 9 & 148 & 20 & 168 \\
\hline 7 & WAL-MART STORES & 64 & 40 & 45 & 28 & 73 \\
\hline 8 & PFIZER & 62 & 65 & 67 & 70 & 137 \\
\hline 9 & INTEL & 58 & 31 & 70 & 37 & 107 \\
\hline 10 & GENERAL ELECTRIC & 57 & 87 & 35 & 54 & 89 \\
\hline 11 & GOLDMAN SACHS GROUP & 49 & 12 & 65 & 16 & 81 \\
\hline 12 & SBC COMMUNICATION & 47 & 81 & 45 & 78 & 123 \\
\hline 13 & HOME DEPOT & 43 & 15 & 99 & 35 & 134 \\
\hline 14 & ORACLE CORP & 42 & 7 & 62 & 10 & 72 \\
\hline 15 & CHEVRON CORP & 40 & 53 & 21 & 28 & 49 \\
\hline 16 & AMGEN & 39 & 3 & 100 & 8 & 108 \\
\hline 17 & CONOCOPHILLIPS & 38 & 27 & 48 & 34 & 83 \\
\hline 18 & TIME WARNER & 37 & 8 & 230 & 50 & 280 \\
\hline 19 & DISNEY (WALT) & 36 & 7 & 83 & 17 & 100 \\
\hline 20 & JPMORGAN CHASE & 35 & 45 & 26 & 34 & 60 \\
\hline 21 & BANK OF AMERICA & 33 & 58 & 36 & 63 & 100 \\
\hline 22 & JOHNSON \& JOHNSON & 33 & 52 & 29 & 46 & 75 \\
\hline 23 & PEPSICO & 32 & 25 & 56 & 45 & 101 \\
\hline 24 & UNITEDHEALTH GROUP & 31 & 3 & 73 & 7 & 81 \\
\hline 25 & DIRECTV GROUP & 30 & 0 & 192 & 0 & 192 \\
\hline
\end{tabular}

Source: Standard and Poor's Compustat database, corrected from company 10-K filings by Mustafa Erdem Sakinç, The Academic-Industry Research Network

Moreover, whether a company is being built up through a process of value creation or being torn down through a process of value extraction, it will take time before the full impact on innovation and economic performance will manifest thesmselves. One needs to have a team of researchers studying a particular industry and its key companies, and update the analysis in (almost) real time. Given their entrenched positions in their industries, and hence the stream of profits they generate, most of the companies in Table 8 can expend more than $100 \%$ of net income on buybacks and dividends for years on end before hitting a financial wall. But if they do not innovate to create new sources of profits, sooner or later they will hit a financial wall.

For example, our research over the past decade has followed the cases of IBM and Hewlett-Packard (HP), \#2 and \#6 respectively in the list of top repurchasers for 2004-2013, and two iconic companies in the history of innovative enterprise. Over the past two years, HP has shown clear signs of hitting the financial wall. From 2004 to 2011, HP did $\$ 61.4$ billion in buybacks, equal to $120 \%$ of its net income, along with $\$ 6.8$ billion in dividends. Unlike IBM, however, HP largely failed in its attempt to shift from selling hardware to high-margin software and services. ${ }^{137}$ After spending

137 Rachelle Dragani, "HP rearranges chairs in hopes of propelling turnaround" E-Commerce Times, August 23, 2013. 
Who Invests in the High-Tech Knowledge Base?

$\$ 11.0$ billion on buybacks in 2010 and $\$ 10.1$ billion in 2011 , the company took a $\$ 12.7$ billion loss in 2012. In $2013 \mathrm{HP}$ had stagnant revenues but restored its profitability by cutting its labor force from 349,600 to 331,800, a first installment of 50,000 layoffs announced as of May 2014 as part of the company's restructuring plan.138

IBM also has the buyback habit, but it has yet to show clear signs of hitting the financial wall. Given the company's financialized strategy, however, the company, which turned 100 in 2013, is clearly engaged in an end game. From the mid-1990s, focusing on software and services, and shedding most of its manufacturing capabilities, IBM led the U.S. offshoring movement. By 2008 the company employed 398,000 people, but only $30 \%$ of them were in the United States, down from $52 \%$ in 1996. In 2011, with its operating earnings per share (EPS) at \$13.44, IBM announced its "2015 EPS Road Map", the objective of which is to reach at least $\$ 20$ EPS by the end of $2015 .{ }^{139}$ Along with revenue growth and operating leverage, IBM cited stock repurchases as a driver in achieving its EPS objective. One way in which IBM is now increasing "operating leverage", and hence higher EPS, is through layoffs of U.S. employees. Another way is through stock buybacks. ${ }^{140}$ In addition to the $\$ 116$ billion in buybacks that the company did from 2004 through 2013 (92\% of net income), IBM did another $\$ 11.8$ billion (181\% of net income) in the first half of 2014 .

Like many other U.S. companies in a wide range of industries, both HP and IBM are on a path that destroys value much more than one that creates value. Both have largely opted out of investing in the knowledge base, high-tech or otherwise. But if these companies don't invest in the knowledge base, which companies will? Apple? Google? Amazon? Facebook? We will have to continue to study these companies to find the answers to our question. We think that it is one worth asking.

\footnotetext{
138 Jack Hough, “Meg Whitman's turnaround at HP,” Barron's, April 7, 2014, p. 19; Spencer E. Ante, “Hewlett-Packard layoffs reflect effort to keep pace with revenue slide," Wall Street Journal, May 29, 2014.

139 http://www.ibm.com/annualreport/2011/ghv/\#five

140 Heidi Moore, "IBM fires small-town workers work Wall Street numbers," The Guardian, March 2, 2014; Nick Summers, "the Trouble with IBM," Bloomberg BusinessWeek, May 22, 2014; Steve Denning, "Why IBM is in decline," Forbes, May 30, 2014.
} 